BRANKO KINCL I VELIMIR NEIDHARDT

Hrvatska akademija znanosti i umjetnosti

\section{Novi putnički terminal Međunarodne zračne luke Franjo Tuđman u Zagrebu - nova vrata Hrvatske}

THE DEPARTMENT OF FINE ARTS

THE FINE ARTS ARCHIVES

ART BULLETIN 67 (2018)

ESSAY

UDC 711.553.9(497.521.2)

DOI: https://dx.doi.org/10.21857/y6zolb8k3m

\section{Branko Kincl i Velimir Neidhardt}

full members of the Croatian Academy of Sciences and Arts

The new passenger terminal at Franjo Tuđman International Airport in Zagreb - the new door to Croatia
Novi putnički terminal Međunarodne zračne luke Franjo Tuđman uZagrebu djelojearhitekata Branka Kincla i Velimira Neidhardta te konstruktora Jure Radića i jedno od najvećih ostvarenja suvremene arhitekture u Hrvatskoj. Smješten na rubnom području grada, predstavlja jedinstveno žarište urbane djelotvornosti metropolskog područja grada Zagreba te novu osnovicu urbanizacije grada Velike Gorice s potencijalno snažnom simbolikom i ekonomskim odrazom na zagrebački metropolski, nacionalni i širi regionalni prostor.

Ključne riječi: Zračna luka Franjo Tuđman; umjetnička interpretacija arhitektonskog oblika; modularna mreža; čelična prostorna konstrukcija; kompjutorsko modeliranje.
The new passenger terminal at Franjo Tuđman International Airport in Zagreb, the work of architects Branko Kincl and Velimir Neidhardt and civil engineer Jure Radić, is one of the greatest creations of modern architecture in Croatia. Located on the outskirts of the city, it represents the unified focal point of the urban efficiency of Zagreb's metropolitan area and a new basis for the urbanisation of the city of Velika Gorica with a potential for strong symbolism and a strong economic effect on Zagreb's urban area, the nation at large, and the greater region.

Key words: Franjo Tuđman Airport, artistic interpretations of architectural form, modular network, steel spatial construction, computer modelling. 


\section{Međunarodni natječaj}

Godine 2008. održan je međunarodni pozivni natječaj za izradu idejnog urbanističko-arhitektonskog rješenja radi odabira najboljeg projekta za novi putnički terminal Međunarodne zračne luke Zagreb.

Međunarodni natječajni žiri stručnjaka te predstavnika vlasti, provoditelja i raspisivača djelovao je u sljedećem sastavu: generalni direktor Boško Matković, predstavnik Zračne luke Zagreb, arhitekt Jerko Rošin, predstavnik Vlade Republike Hrvatske, arhitektica Jadranka Veselić-Bruvo, predstavnica Grada Zagreba, Boško Pribičević, predstavnik Zagrebačke županije i Grada Velike Gorice, arhitekt Dietmar Eberle, Baumschlager Eberle iz Lochaua, Austrija, arhitekt Norbert Koch, K+P Architekten und Stadtplaner GmbH iz Münchena, arhitekt Gudmund Stokke, Aviaplan, iz Osla, arhitekt Veljko Olujić, predstavnik DAZ-a, arhitekt Saša Begović, predstavnik UHA-
Novi putnički terminal Međunarodne zračne luke Franjo Tuđman u Zagrebu, pobjednički rad na međunarodnom natječaju

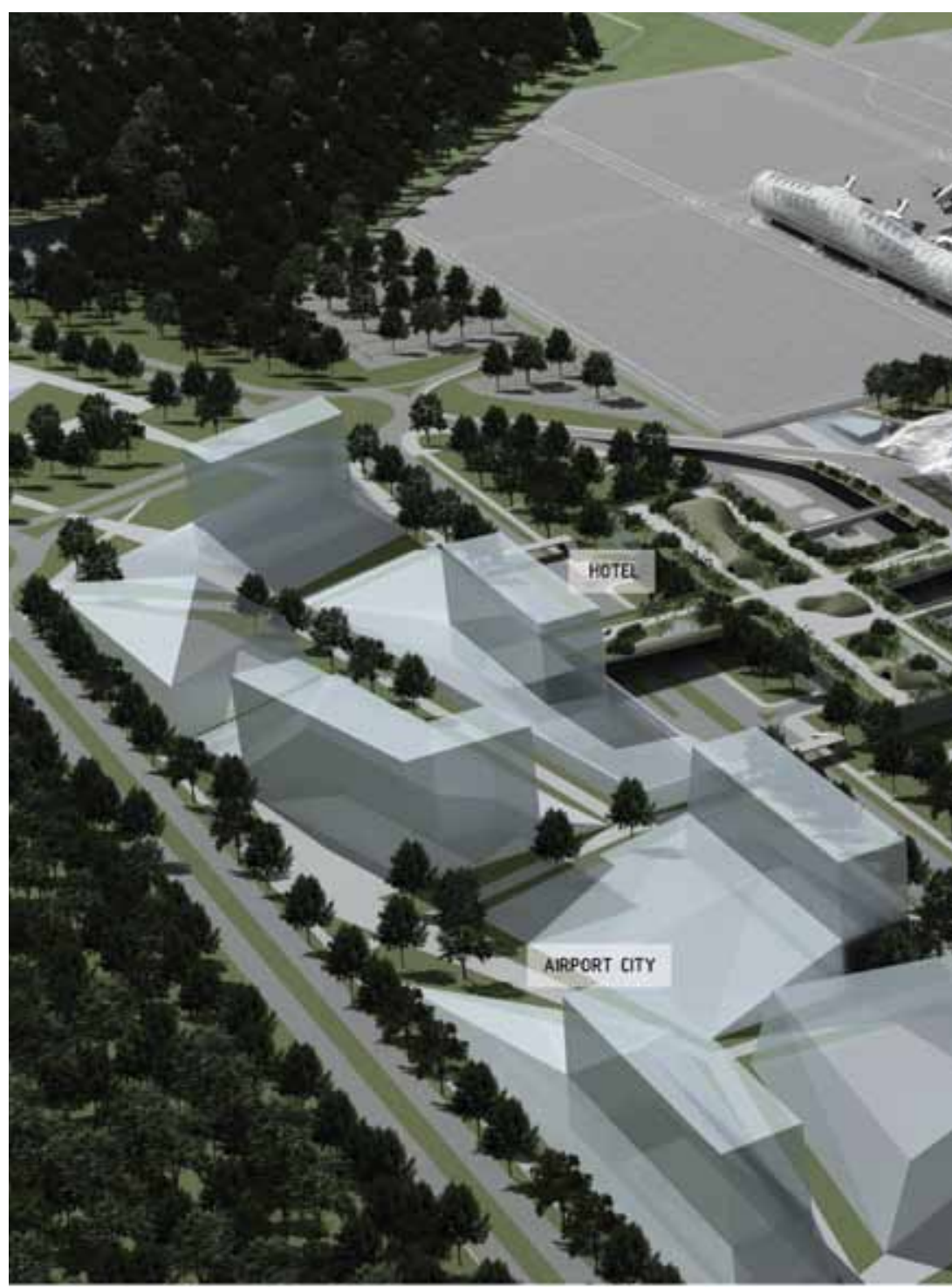




\section{International tender}

New Passenger Terminal at Franjo Tudman International Airport Zagreb, 1st-prize-winning design at tender

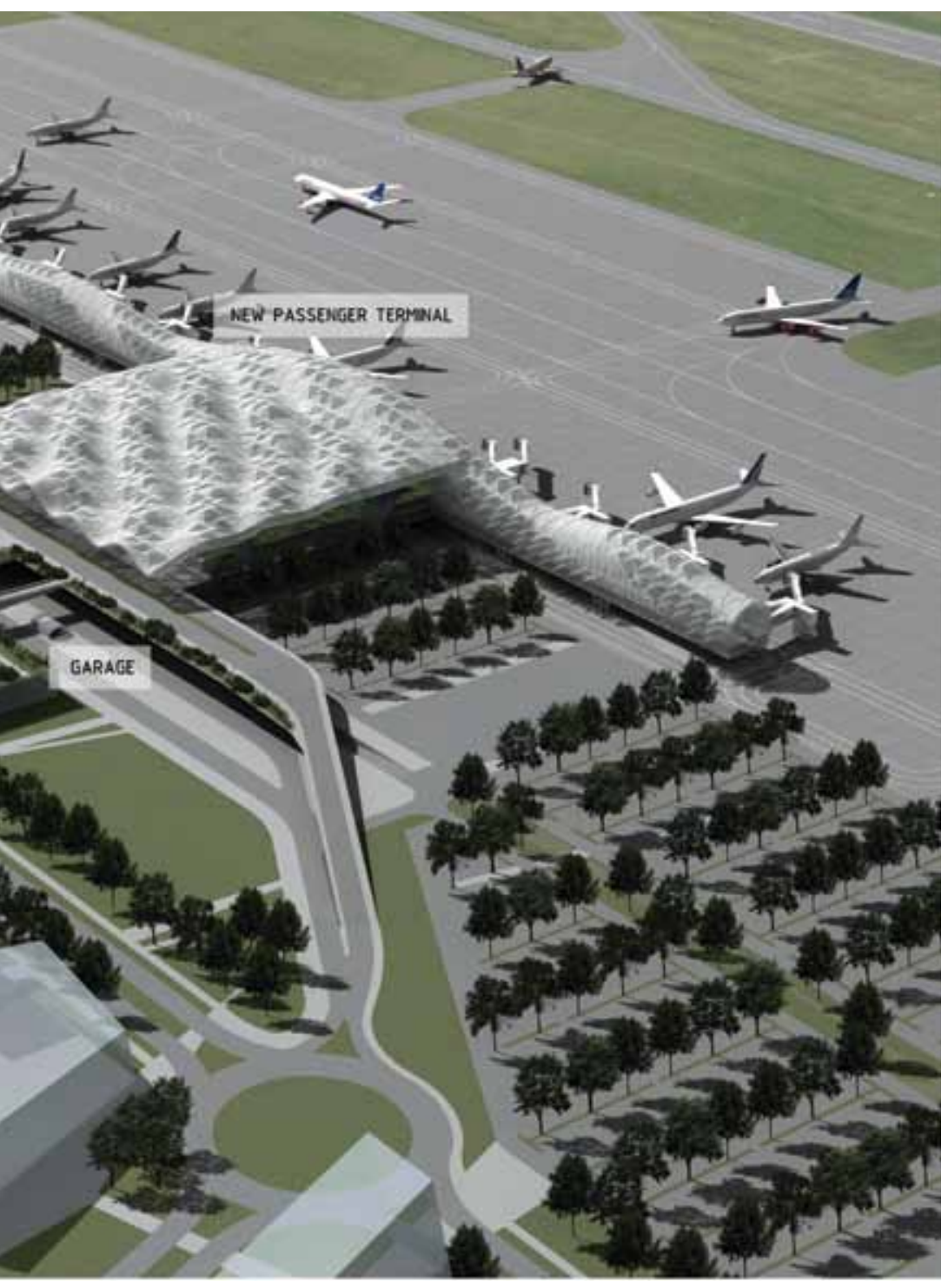

In 2008, an international invitational tender was held to select the best urban and architectural design for the new passenger terminal at Zagreb International Airport.

The jury for the international tender consisted of the following experts, and representatives of the government, the authors and executors of the tender: Zagreb Airport's general director Boško Matković; architect and Croatian government representative Jerko Rošin; architect and Zagreb city government representative Jadranka Veselić-Bruvo; representative of Zagreb County and the city of Velika Gorica Boško Pribičević; architect Dietmar Eberle from architectural bureau Baumschlager Eberle from Lochau, Austria; architect Norbert Koch from architectural bureau $\mathrm{K}+\mathrm{P}$ Architekten und Stadtplaner $\mathrm{GmbH}$ from Munich; architect Gudmund Stokke from architectural bureau Aviaplan from Oslo; architect Veljko Olujić, representative of the Zagreb Architects' Association; architect Saša Begović, representative of the Croatian Association of Architects; Gaetan Siew, representative of Union Internationale des Architectes from Paris; expert advisers Dr. Boris Androić, Dr. Tonko Ćurko, Dr. Jasenka Bertol-Vrček, and Dr. Stanislav Pavlin.

In order to achieve architectural excellence, ten internationally recognised architects were invited to the tender: Shigeru Ban Architects, Tokyo; 
Spühler Architekten AG, Zurich, Zaha Hadid Architects, London, Kazuyo Sejima, Tokyo, Riegler Riewe Architects Ges.m.b.H., Graz, Steven Holl, New York, te ADPI designers \& planers Paris u suradnji s kiparom Dušanom Džamonjom iz Zagreba. Pozvano je i deset renomiranih hrvatskih arhitekata odabranih u pretkvalifikacijama: de Architekten CIE, Zagreb, IGH d.d. \& Neidhardt arhitekti d.o.o. \& Kincl d.o.o., Zagreb, GI_Tower 151 Architects \& Studio A, Zagreb, Randić-Turato d.o.o., Rijeka, Radionica arhitekture d.o.o. \& Ar-
J.S.K. Architekten, Frankfurt; Nicolas Grimshaw Architect, London; Foster+Partners, London; Martin Spühler Architekten AG, Zurich; Zaha Hadid Architects, London; Kazuyo Sejima, Tokyo; Riegler Riewe Architects Ges.m.b.H., Graz; Steven Holl, New York; ADPI designers \& planners Paris in cooperation with sculptor Dušan Džamonja from Zagreb. Ten renowned Croatian architects approved in prequalifications were also invited: de Architekten CIE, Zagreb; IGH d.d. \& Neidhardt arhitekti d.o.o. \& Kincl d.o.o., Zagreb; GI_Tower
Novi putnički terminal Međunarodne zračne luke Franjo Tuđman u Zagrebu, dinamička krovna konstrukcija
New Passenger Terminal at Franjo Tudman International Airport Zagreb, dynamic roof structure 
hingtrade d.o.o., Zagreb, Penezić \& Rogina arhitekti d.o.o., Zagreb, AJF projekt d.o.o. \& Arhitektura Lozica d.o.o., Zagreb, Studio BF d.d., Zagreb, Arhitektonski biro Ante Kuzmanić d.o.o., Split, Urbane tehnike d.o.o. \& Ivica Čović, Zagreb.

Nakon vrednovanja svih natječajnih radova, pobjedničkim radom proglašen je projekt pod šifrom 1007 autora akademika Branka Kincla, dipl. ing. arh., akademika Velimira Neidhardta, dipl. ing. arh., i prof. dr. sc. Jure Radića, dipl. ing. građ. $\mathrm{Na}$ spomenutom projektu sudjelovali su eksperti
151 Architects \& Studio A, Zagreb; Randić-Turato d.o.o., Rijeka; Radionica arhitekture d.o.o. \& Arhingtrade d.o.o., Zagreb; Penezić \& Rogina arhitekti d.o.o., Zagreb; AJF projekt d.o.o. \& Arhitektura Lozica d.o.o., Zagreb; Studio BF d.d., Zagreb; Arhitektonski biro Ante Kuzmanić d.o.o., Split; Urbane tehnike d.o.o. \& Ivica Čović, Zagreb.

After an evaluation of all works submitted for the tender, a project under code 1007 was announced the winner, created by Academician Branko Kincl, Academician Velimir Neidhardt,

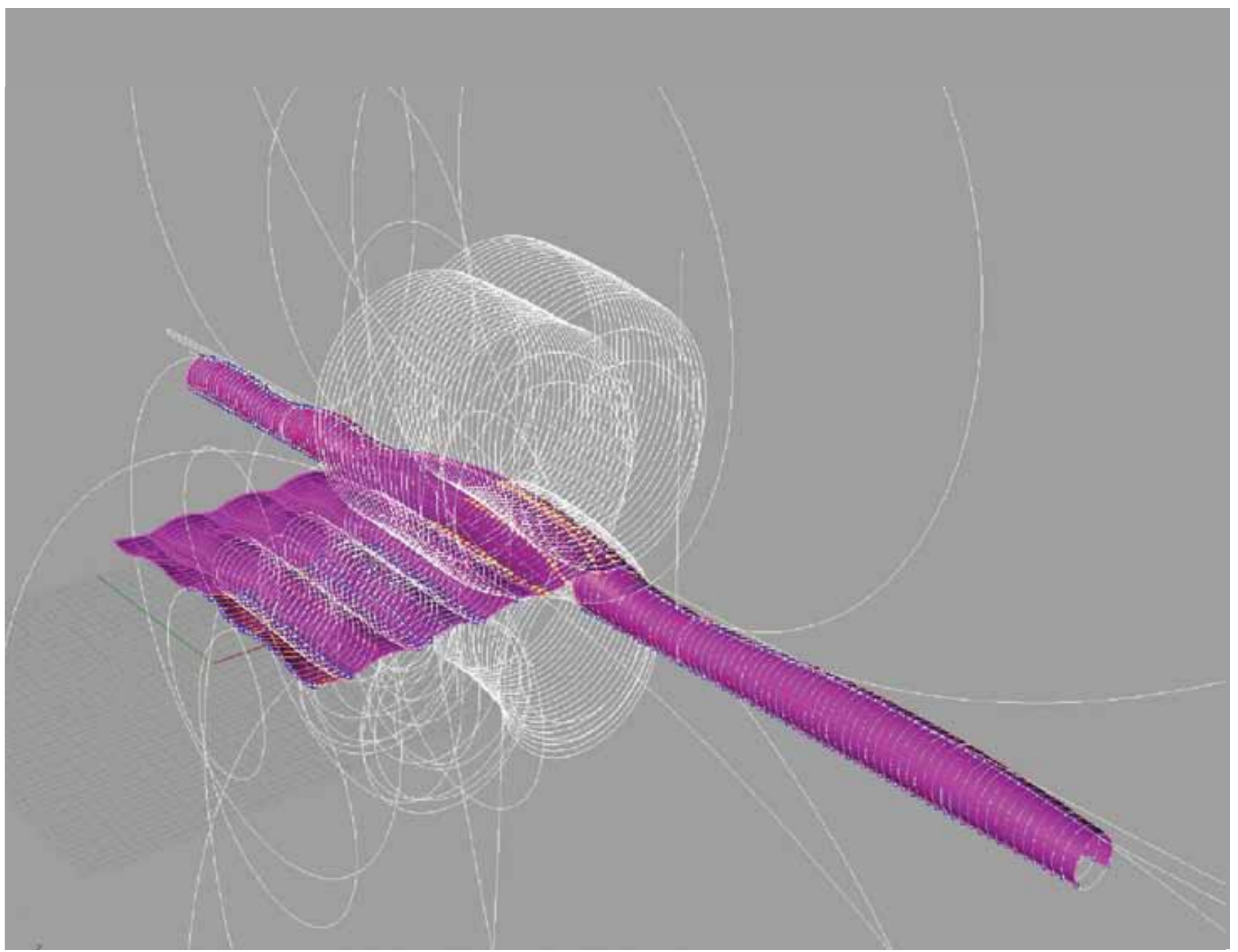

Novi putnički terminal Međunarodne zračne luke Franjo Tuđman u Zagrebu, strukturni model ovojnice
New Passenger Terminal at Franjo Tudman International Airport Zagreb, structural model of the envelope 
Novi putnički terminal Međunarodne zračne luke Franjo Tuđman u Zagrebu, zračni prikaz modela

New Passenger Terminal at Franjo Tudman International Airport Zagreb, model aerial view

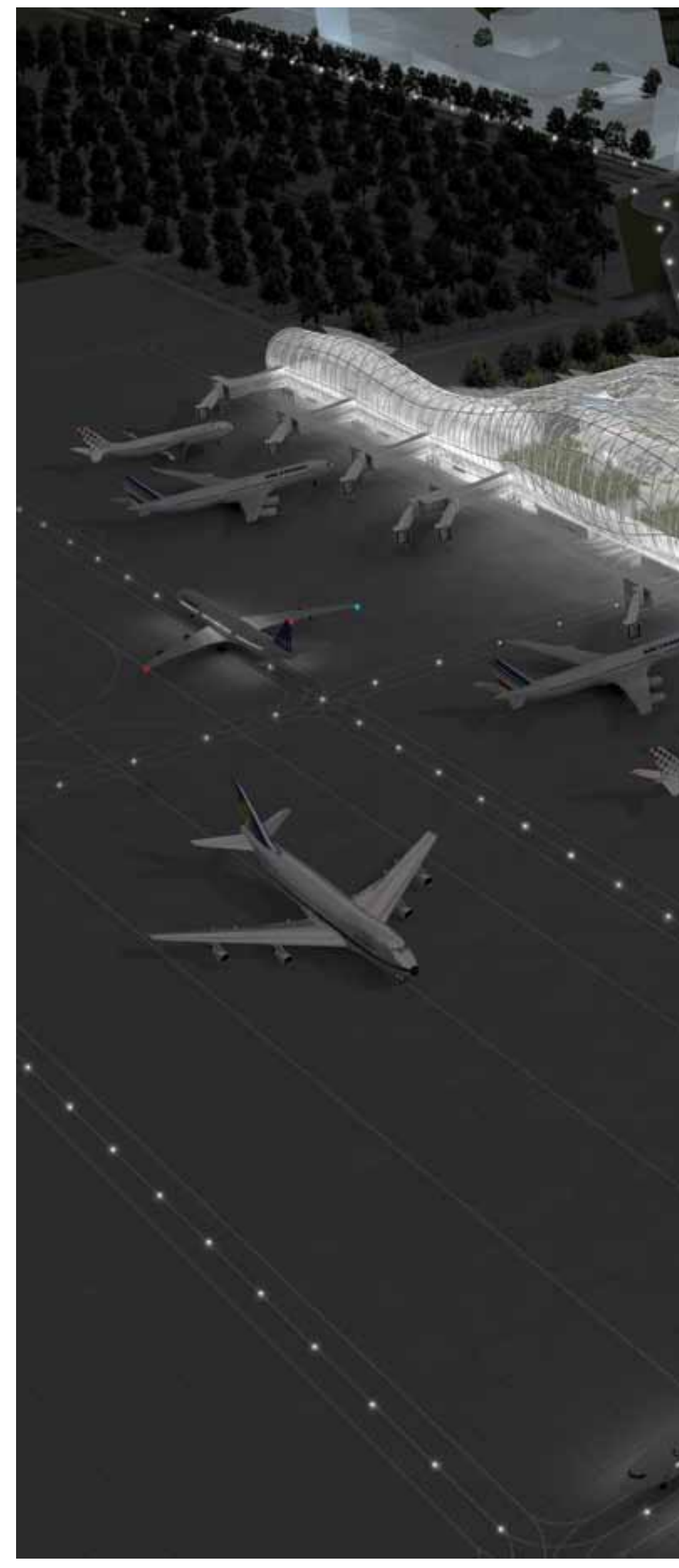


prof. Vladimir Bazjanec, Lawrence Berkeley National Laboratories University of California, Tonči Peović, ing., Slavko Roguljić i Ante Stojan, dipl. ing. arh., te suradnici Venko Ćurlin, dipl. ing. arh., Zvonimir Kralj, dipl. ing. arh., Ivan Ljubić, dipl. ing. arh., Boško Opalić, kand. arh., te Luka Trkanjec, kand. arh. Suradnici na konstrukciji bili su Anđelko Vlašić, dipl. ing. građ., Nijaz Mujkanović, dipl. ing. građ., te Ivan Špišić, dipl. ing. građ., dok je na prometnom rješenju surađivao Stjepan Kralj, dipl. ing. građ., a na energetskom mr. sc. and Dr. Jure Radić. The project also involved the following experts: Prof. Vladimir Bazjanec, Lawrence Berkeley National Laboratories, University of California; engineer Tonči Peović; architectural engineers Slavko Roguljić and Ante Stojan; associates Venko Ćurlin, Zvonimir Kralj, Ivan Ljubić, Boško Opalić, and Luka Trkanjec. The construction associates were Anđelko Vlašić, Nijaz Mujkanović, and Ivan Špišić. Transport infrastructure design was provided by Stjepan Kralj, while energy infrastructure design was provided

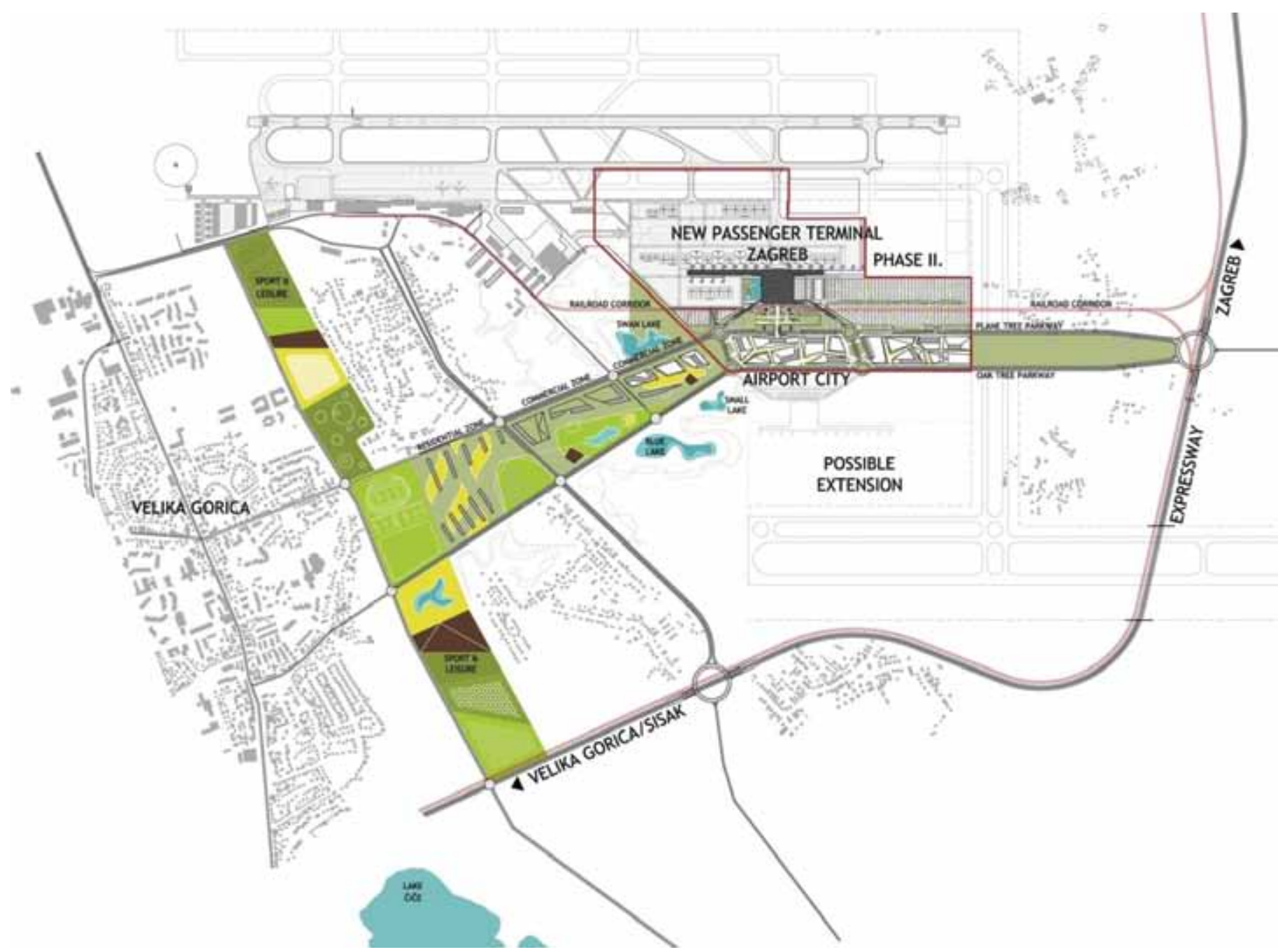

Novi putnički terminal Međunarodne zračne luke Franjo Tuđman u Zagrebu, koncept urbanističkog plana
New Passenger Terminal at Franjo Tudman International Airport Zagreb, urban planning concept 
Ognjen Bergam, dipl. ing. el., doc. dr. sc. Miodrag Drakulić, dipl. ing. stroj., te izv. prof. dr. sc. Nenad Ravlić, dipl. ing. građ. Vizualizacije rada djelo su Ane Kunst, dipl. ing. arh., i Magnusa Lundstroma, dipl. ing. arh.

Preostale nagrade dodijeljene su redom: II. nagrada - Shigeru Ban, dipl. ing. arh., i Taro Okabe, dipl. ing. arh.; III. nagrada - Foster+Partners, London, Velika Britanija; IV. nagrada - Andrew Yeoman, dipl. ing. arh., Tower 151 Architects - Zagreb d.o.o.; John Cramer, dipl. ing. arh., Tower 151 by Ognjen Bergam, Dr. Miodrag Drakulić, and Dr. Nenad Ravlić. Visualisations were the work of Ana Kunst and Magnus Lundstrom.

The remaining awards were distributed as follows: $2^{\text {nd }}$ place - Shigeru Ban and Taro Okabe; $3^{\text {rd }}$ place - Foster+Partners, London, Great Britain; $4^{\text {th }}$ place - Andrew Yeoman, Tower 151 Architects - Zagreb d.o.o.; John Cramer, Tower 151 Architects - Zagreb d.o.o.; Duncan Berntsen, RIBA; David Andreen; Brent McDonald; $5^{\text {th }}$ place - Zaha Hadid Limited, London, Great Britain; $1^{\text {st }}$ honour-

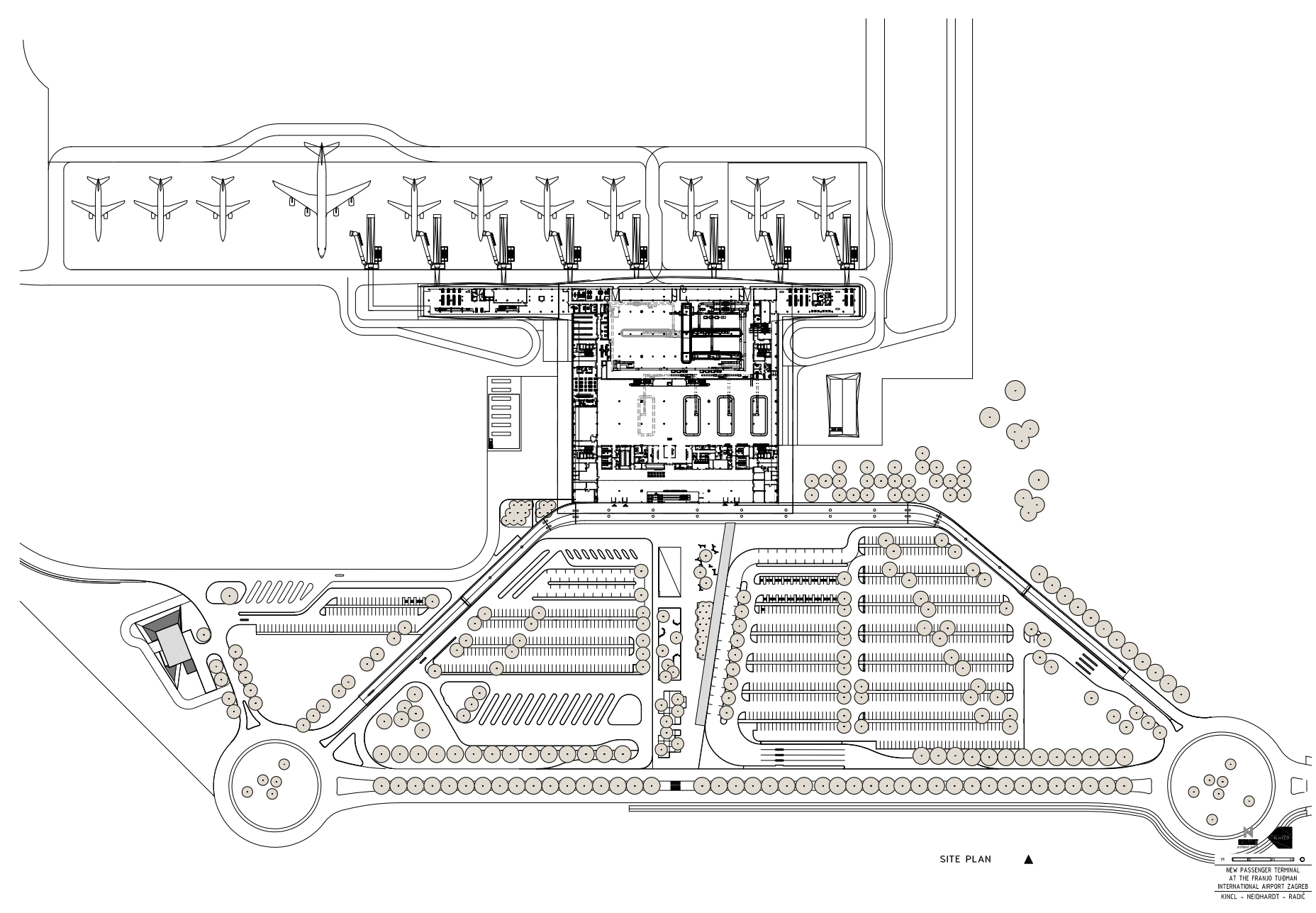

Novi putnički terminal Međunarodne zračne luke Franjo Tuđman u Zagrebu, glavni plan
New Passenger Terminal at Franjo Tudman International Airport Zagreb, master plan 
Architects - Zagreb d.o.o.; Duncan Berntsen, dipl. ing. arh., RIBA; David Andreen; Brent McDonald; V. nagrada - Zaha Hadid Limited, London, Velika Britanija; te I. otkup - Nicolas Grimshaw Architects LLP, London, Velika Britanija; II. otkup - Studio BF d.o.o. Zagreb; III. otkup - ADPI designers \& planers Paris, France; IV. otkup - J.S.K. Architekten, Frankfurt, Njemačka.

Ocjenjivački je sud pobjednički rad nagradio visokim ocjenama dodijelivši mu iznimne epitete. Komentar žirija prenosimo u cijelosti: able mention - Nicolas Grimshaw Architects LLP, London, Great Britain; $2^{\text {nd }}$ honourable mention Studio BF d.o.o. Zagreb; $3^{\text {rd }}$ honourable mention - ADPI designers \& planers Paris, France; $4^{\text {th }}$ honourable mention - J.S.K. Architekten, Frankfurt, Germany.

The jury awarded the winning project high marks and superlatives. The following is the jury's unabridged commentary:

"The terminal building is similar to an elongated mast, showing a combination of the long, lin-

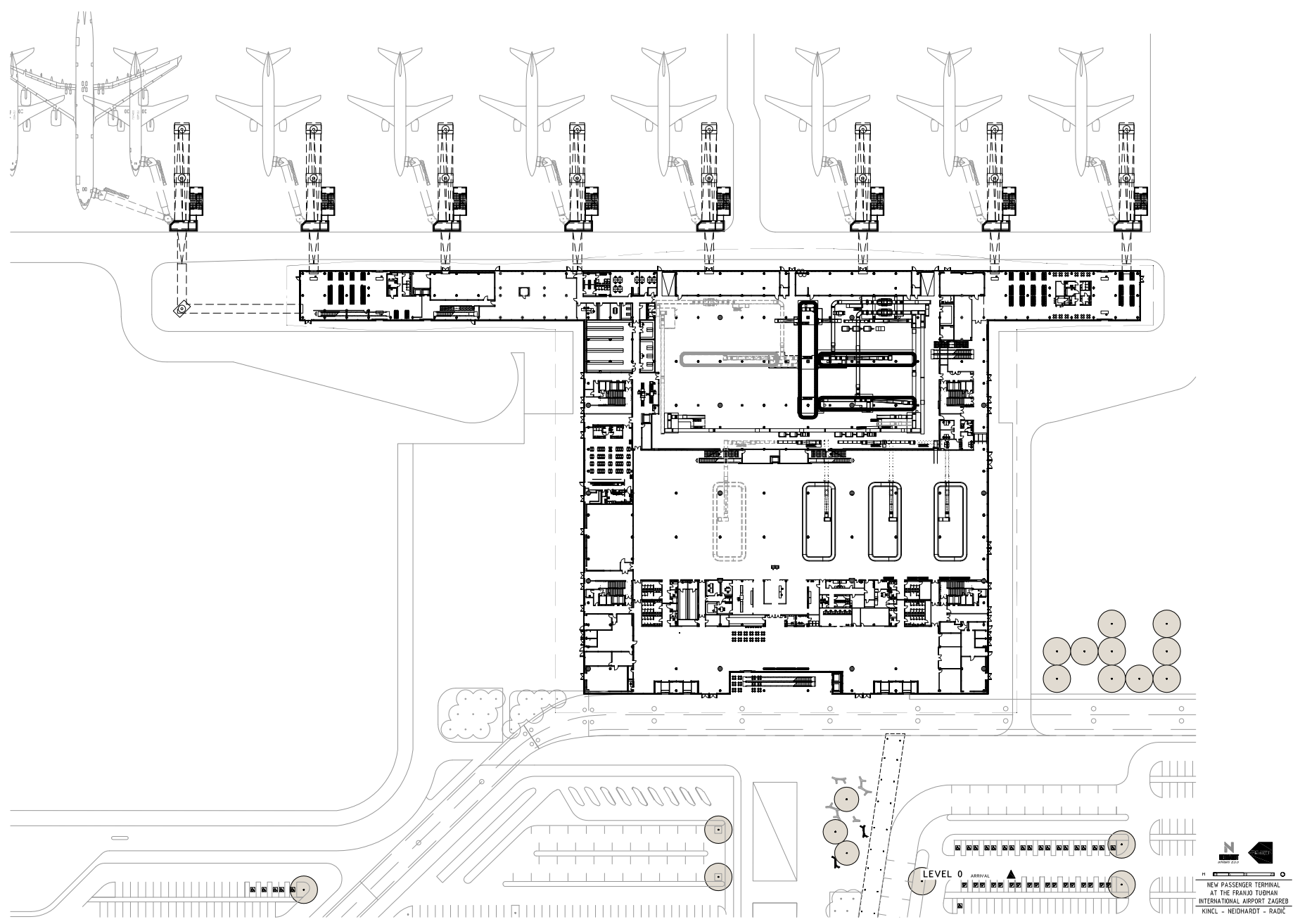

Novi putnički terminal Međunarodne zračne luke Franjo Tuđman u Zagrebu, prizemlje
New Passenger Terminal at Franjo Tudman International Airport Zagreb, ground floor 
„Zgrada terminala sliči izduženom jarbolu, prikazujući kombinaciju duge, linearne induktivne strukture stijega, nježno uvijene u dinamičnu envelopu koja se otvara i levitira iznad prostora terminala, time stvarajući slobodnu dinamiku strukturalne mreže - lebdeći krov - ikonički izraz krajobraza.“

„Izvanredna arhitektura s detaljno elaboriranom tehnologijom.“

„Projekt ima veoma snažan koncept s potencijalom da postane aerodromski terminal svjetske ear, inductive structure of a banner gently twisted into a dynamic envelope that opens and levitates above the terminal space, thereby creating the free dynamics of the structural network - the floating roof - an iconic expression of the landscape."

"Exceptional architecture with precisely elaborated technology"

"The project has a very powerful concept whose architectural, functional, and technological features give it the potential to become a world class airport terminal. The terminal could thus become

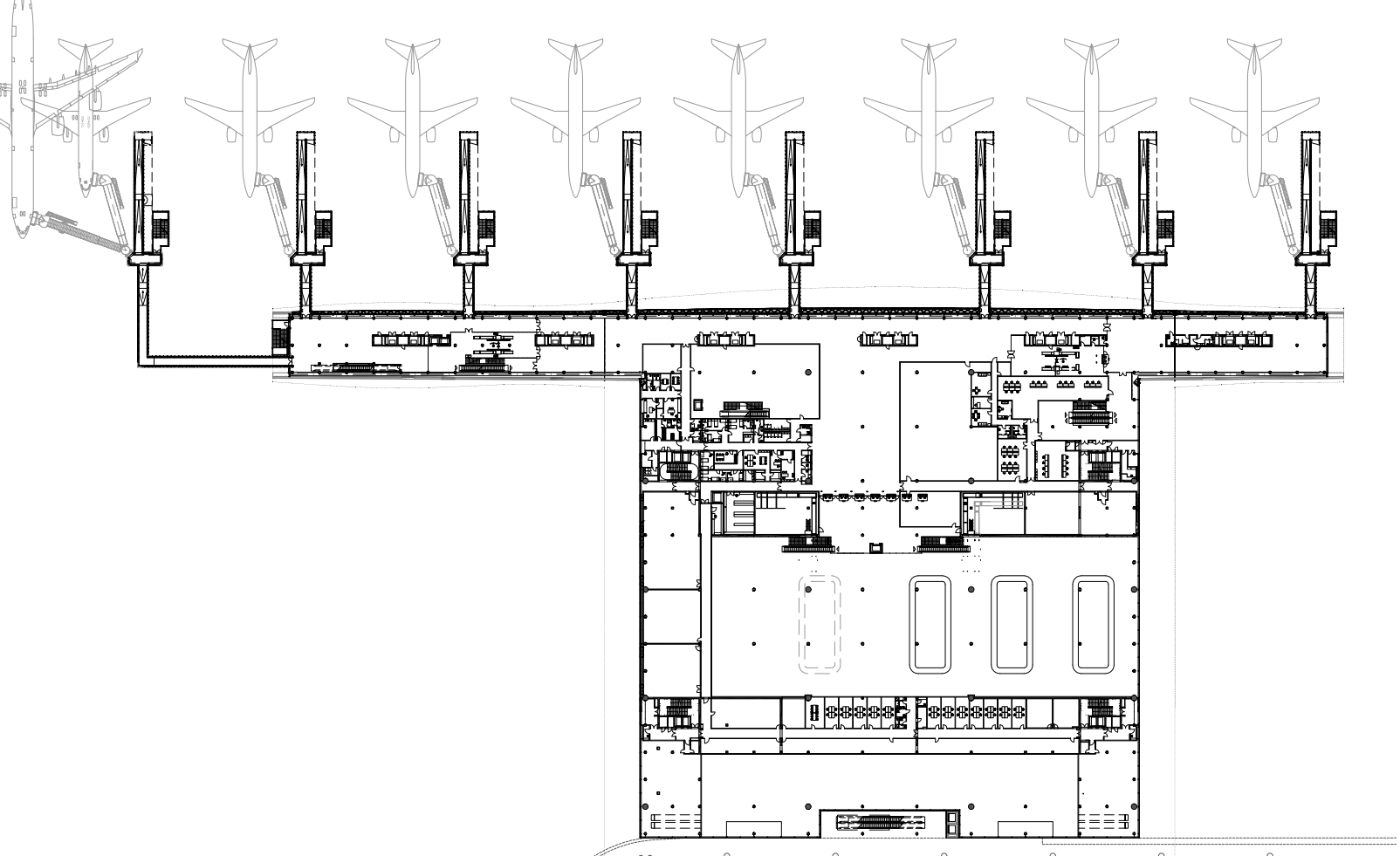

Novi putnički terminal Međunarodne zračne luke Franjo Tuđman u Zagrebu, prvi kat
New Passenger Terminal at Franjo Tudman International Airport Zagreb, first floor 
klase po arhitektonskim, funkcionalnim i tehnološkim karakteristikama. Terminal bi time mogao postati vrata Hrvatske, prezentirajući ju kao naciju najviše kulturne i tehnološke razine razvijenosti.“

„Projekt je najbolji od predanih radova. Odlikuje se vrlo dobro riješenim tokovima putnika i vrlo dobrom funkcionalnošću u kontekstu integracije sustava za rukovanje prtljagom, tokova dobara i osoblja. Zahvaljujući dobrim proporcijama centralne zgrade, moguć je modularan rast do 10 - 15 milijuna putnika na godinu i više. Centralni the door to Croatia, presenting it as a nation of the highest cultural and technological level of development."

"This project is the best of the works submitted. It is characterised by its exceptional passenger flow and high functionality in the context of the integration of its luggage handling systems, flow of goods and staff. The good proportions of the central building allow modular growth of 10-15 million passengers per year and more. The central part of the building is sufficiently deep to ensure
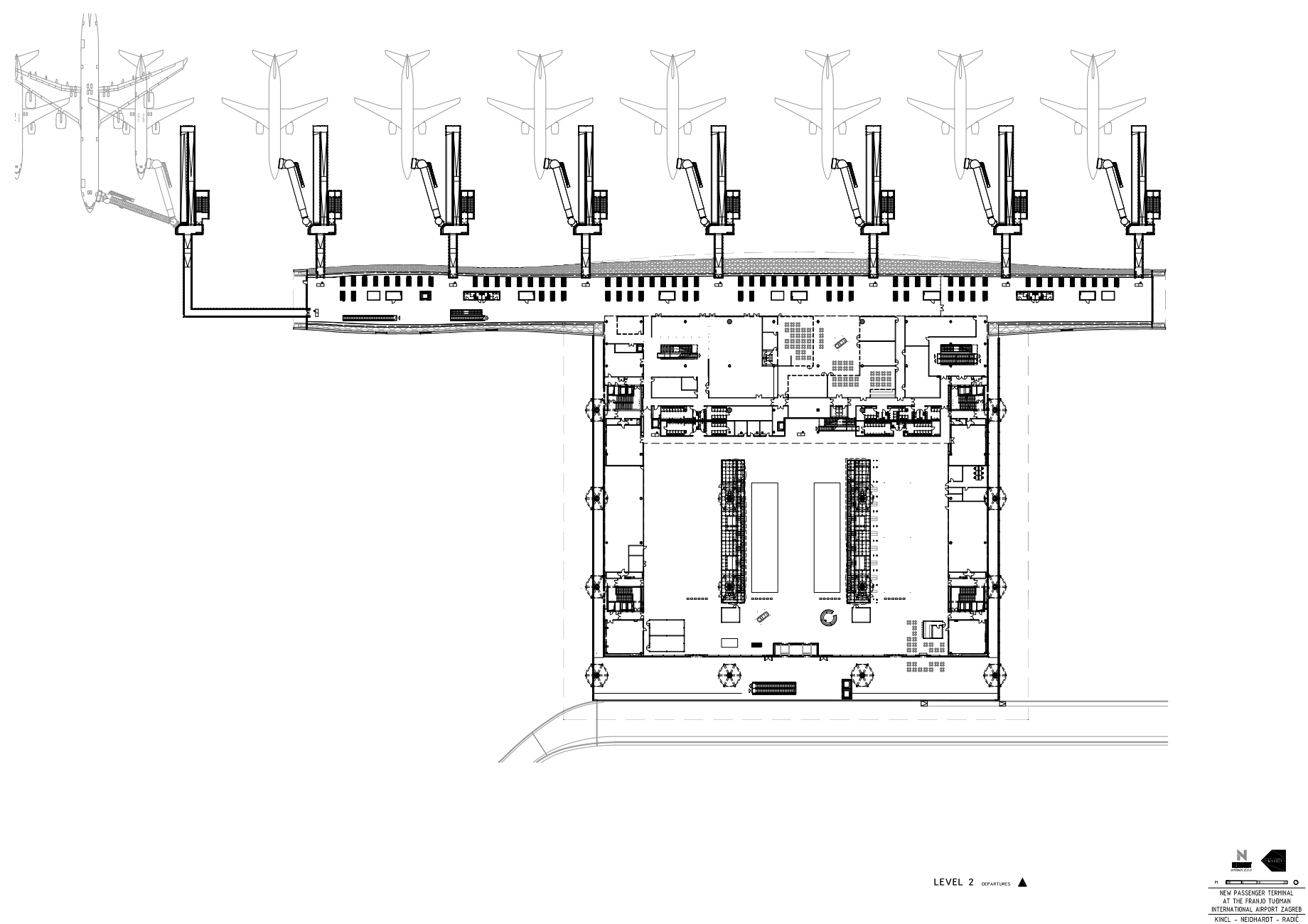

Novi putnički terminal Međunarodne zračne luke Franjo Tuđman u Zagrebu, drugi kat
New Passenger Terminal at Franjo Tudman International Airport Zagreb, second floor 
je dio zgrade dovoljne dubine kako bi se osigurale prostrane zone komercijalne djelatnosti i za prihvat aviona kategorije F. Prostorno oblikovanje poslovnog cityja dobro je postavljeno te stvara povoljnu vezu s prigradskim područjima Velike Gorice. Elektro-energetsko rješenje i strategija očuvanja okoliša najbolja je u natječaju i, iako su potrebna daljnja pojašnjenja i razvoj, osiguravaju dobar balans strukture i prostora. Arhitektonska ekspresija građevine uvelike obećava da će postati zdanje najvišeg međunarodnog ugleda.“ spacious commercial zones and sufficient room for $F$ category planes. The interior design of the business city is well founded, creating a solid connection with the suburban areas of Velika Gorica. The electrical energy infrastructure and environmental protection strategy were the best in the tender; although further explanations and development are needed, they ensure a good balance between structure and space. The architectural expression of the structure promises to make it a building of the highest international renown."

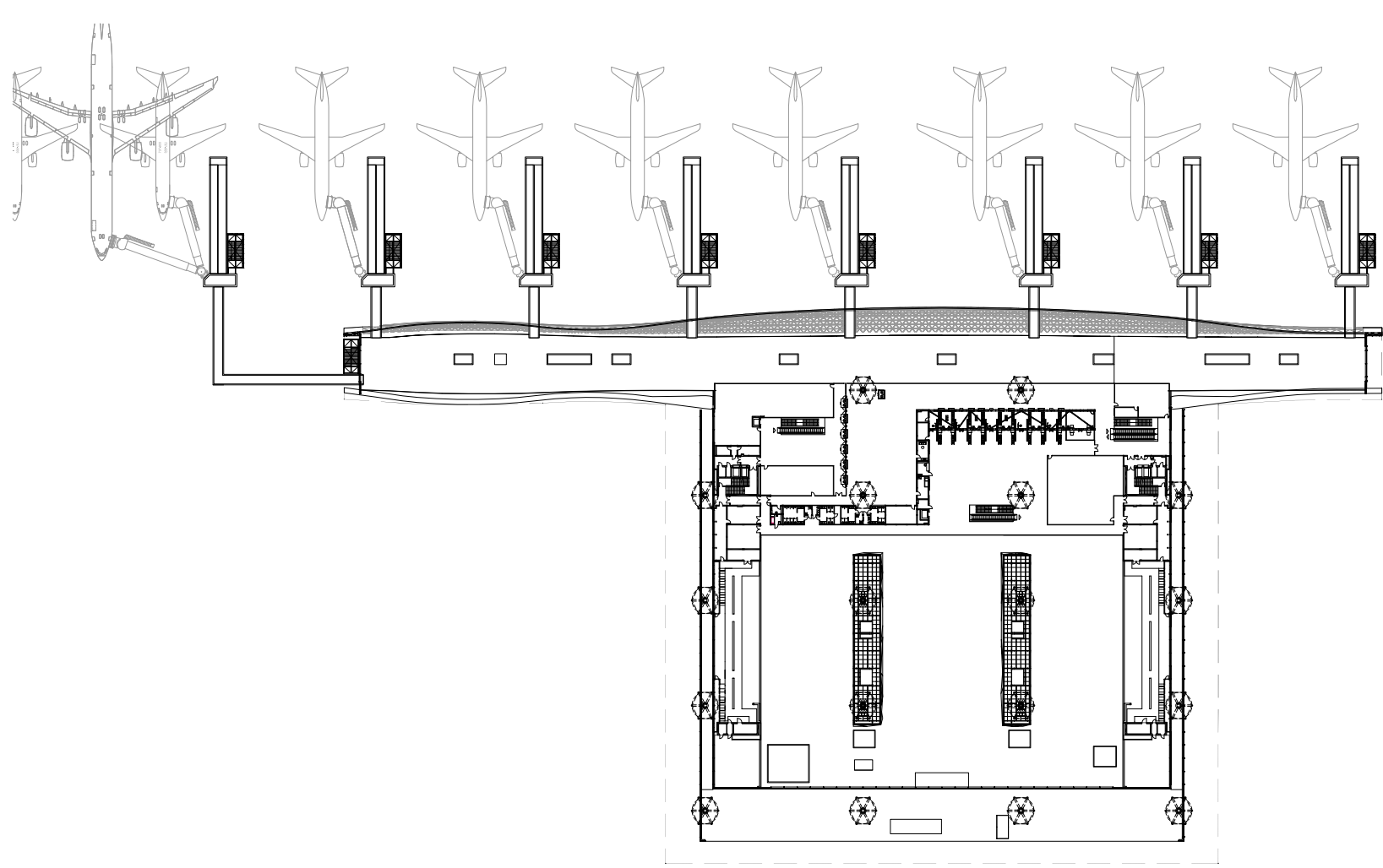

Novi putnički terminal Međunarodne zračne luke Franjo Tuđman u Zagrebu, treći kat
New Passenger Terminal at Franjo Tudman International Airport Zagreb, third floor 
„Ovaj projekt imao je najbolji odgovor na ključne elemente suvremene zgrade terminala - tj. funkcionalnost - proširivost i fleksibilnost. U skladu je sa svim zahtjevima programa u pogledu koncepta prostornog planiranja, dizajna, energetskog koncepta i jednostavnosti odvijanja tokova putnika.“

„Uz najviše ocjene iz tehničkih, funkcionalnih i energetskih karakteristika, ovaj rad postiže najbolju ravnotežu zahtjeva konstrukcije i boravišnih prostora.“

„Koncept konstrukcije pridonosi kreiranju jedinstvenih prostornih kvaliteta u internacionalnom arhitektonskom vokabularu komplementiranom interijerima s lokalnim identitetom.
“This project provided the best answers to the key elements of modern terminal buildings - i.e. functionality, scalability, and flexibility. It complies with all the requirements of the programme regarding spatial planning, design, energy, and ease of passenger flow."

"With the highest ratings for its technical, functional, and energy characteristics, this project reaches the best balance between the demands of construction and passenger spaces."

"The concept of the construction contributes to the creation of unique spatial qualities in an international architectural vocabulary complemented with interiors with a local identity. Travelling thus becomes the art of defining measure - from large

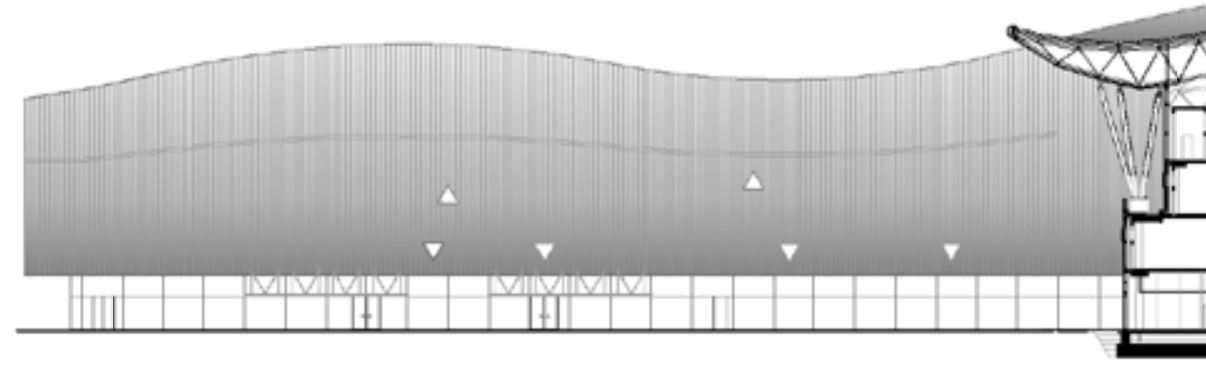




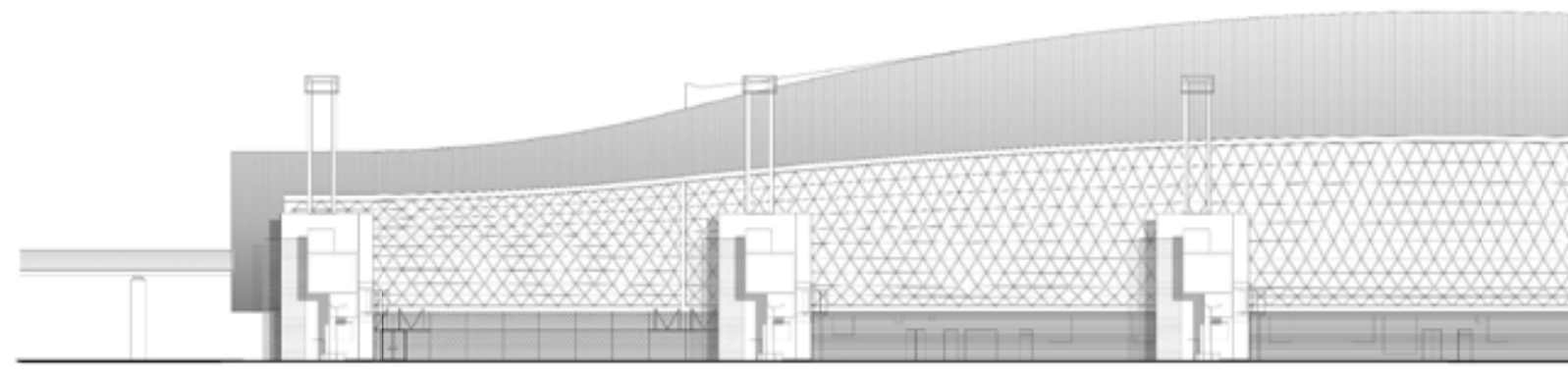

Novi putnički terminal Međunarodne zračne luke Franjo Tuđman u Zagrebu, sjeveroistočna visina

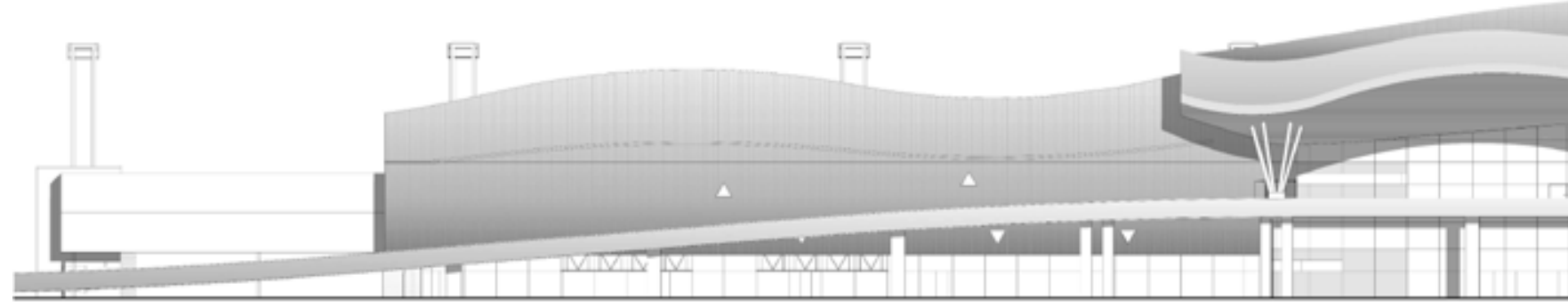

Novi putnički terminal Međunarodne zračne luke Franjo Tuđman u Zagrebu, jugozapadna visina 


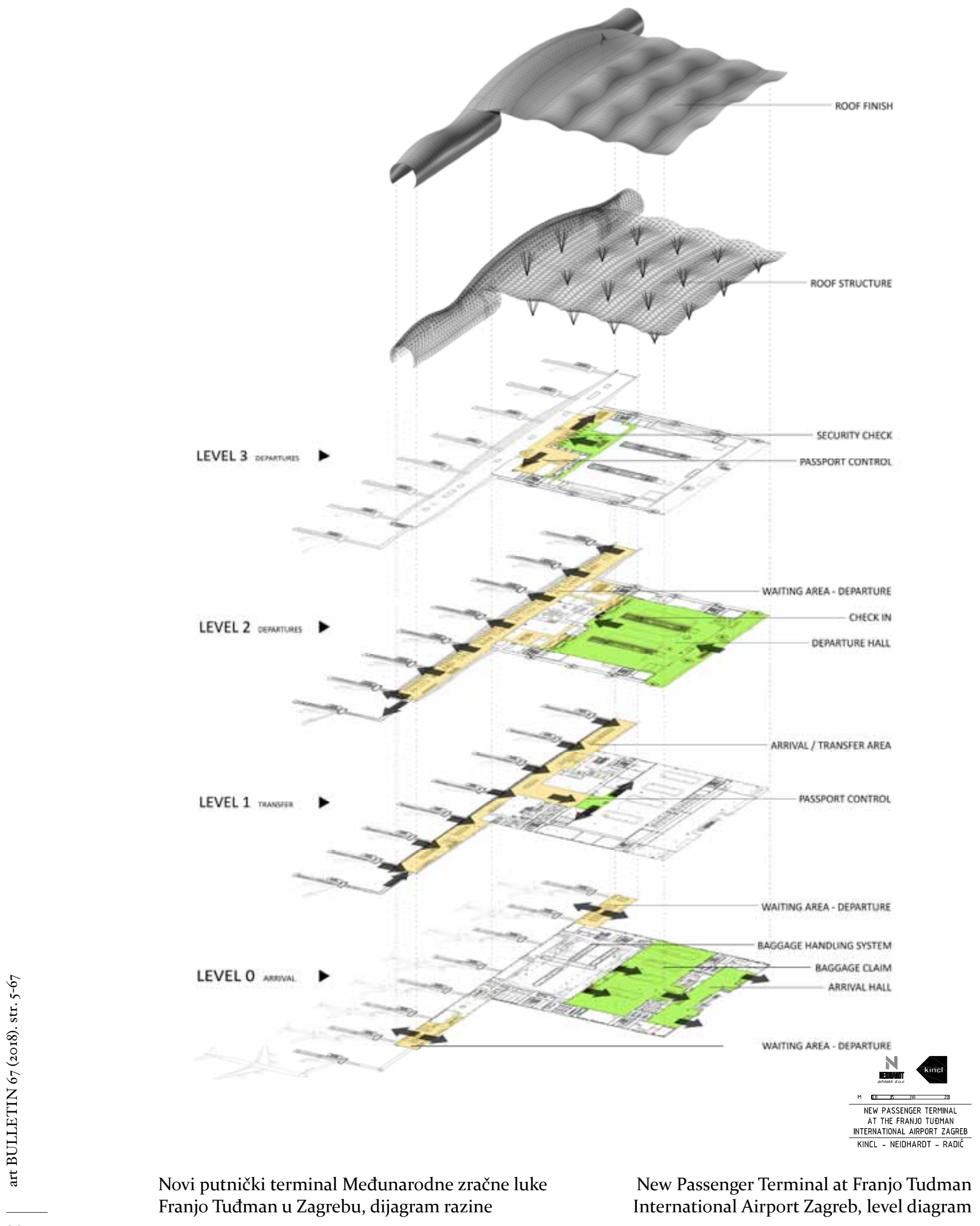


Uz navedeno, nagrađeni je projekt pohvaljen i zbog svojeg energetskog koncepta i ekonomske učinkovitosti, pri čemu se ističu sveobuhvatan opis, pouzdan koncept, korištenje održivih solarnih panela, adekvatni troškovi održavanja, niska energetska ovisnost, mogućnost dogradnje sustava, povoljni faktora oblika i planirano korištenje dvostruke fasade na svim ostakljenim površinama, što pridonosi toplinskoj i zvučnoj zaštiti zgrade.

Osim same zgrade novog putničkog terminala, natječajni je rad obuhvaćao i izgradnju cijelog niza sportskih, rekreacijskih i stambenih zona te poslovnih, trgovačkih i ugostiteljskih građevina kao dio Aerodromskog poslovnog centra - Airport
In addition to this, the winning project was praised for its energy concept and economic efficiency, including its extensive description, reliable concept, the use of sustainable solar panels, adequate maintenance costs, low energy dependency, scalable systems, efficient form factor, and the planned use of a double façade on all windowed surfaces, which contributes to the building's heat and sound insulation.

Aside from the new passenger terminal building itself, the project also includes the construction of a string of sports, recreation, and residential zones, as well as business, commercial, and hospitality buildings as a part of the Airport City business centre, in cooperation with which the new passenger

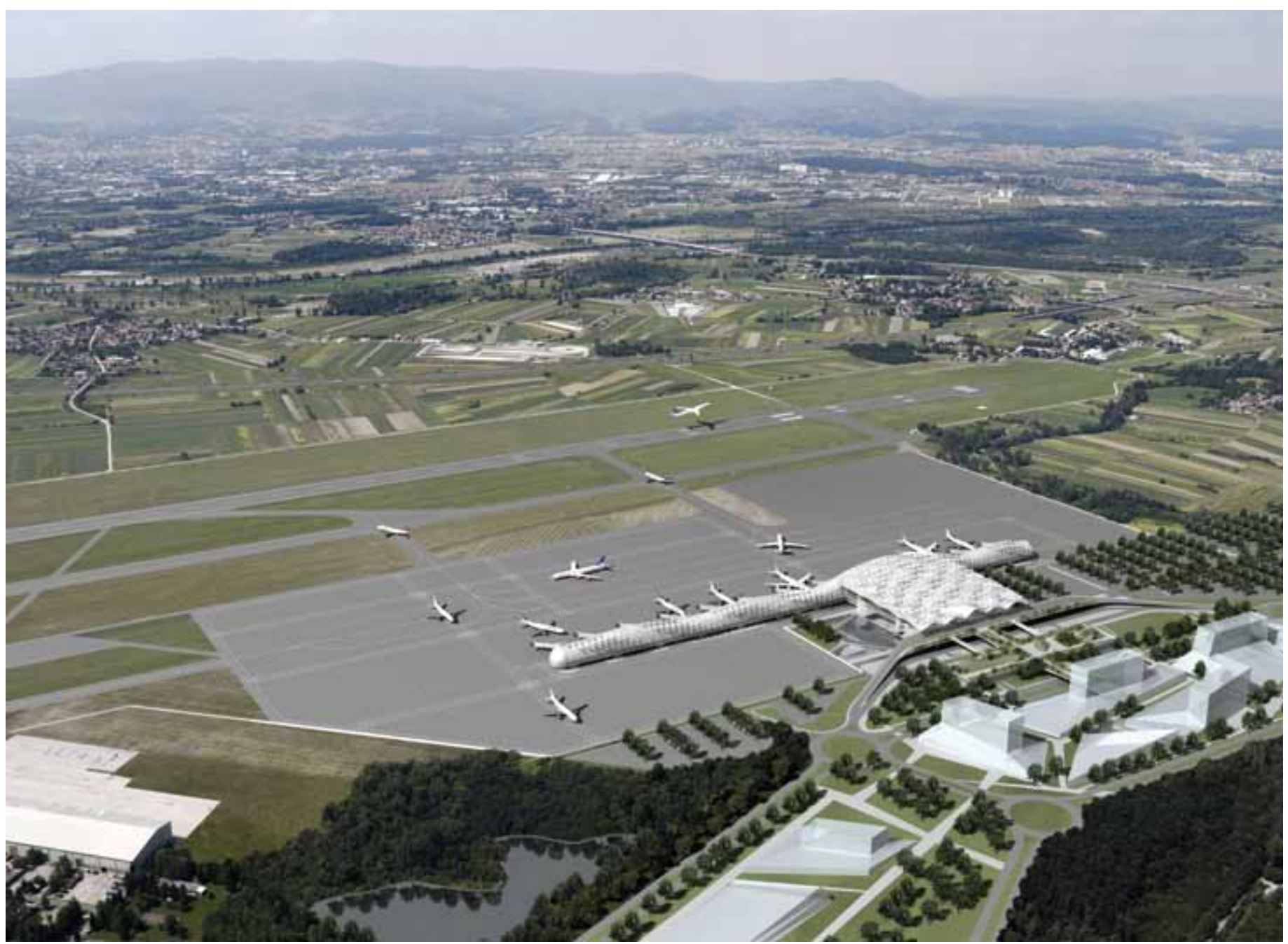

Novi putnički terminal Međunarodne zračne luke Franjo Tuđman u Zagrebu, model iz zraka
New Passenger Terminal at Franjo Tudman International Airport Zagreb, aerial model 
Cityja, u suradnji s kojima bi novi putnički terminal predstavljao osnovicu urbanizacije usmjeravajući silnice razvoja prema urbanom okruženju, posebice prema Velikoj Gorici. Definicija spomenute aglomeracije transformirala bi se kroz novu, kompleksnu distribuciju urbanih struktura koje se formiraju duž novonastalih parkovnih osi povezujući središte Velike Gorice sa zonom novog putničkog terminala. Razvoj ovog segmenta natječajnog rada nije bio predmet razrade prve faze izgradnje aerodroma, međutim, kada se $u$ budućnosti pristupi daljnjem razvoju sklopa aerodromskih zgrada, imat će potencijal postati jedinstveno žarište urbane djelotvornosti metropolskog područja Zagreba, sa snažnom simbolikom i ekonomskim odrazom na nacionalni i širi regionalni prostor.

Idejno rješenje pobjedničkog natječajnog rada predstavlja aglomeraciju kompleksa zračne luke kao sjecište dvaju prostornih nizova: širenja zagrebačkog poslovnog tkiva i, s druge strane, potencijala prigradskog područja Velike Gorice. Kao križište spomenutih nizova, projekt novog putničkog terminala definirao je okosnicu koja povezuje dvije važne gradske osi: središnju zagrebačku simetralu - Gornji grad - Zrinjevac - Most slobode - Buzin do postojećeg kompleksa zračne luke te novu, postindustrijsku zagrebačku istočnu tangentu - Heinzelova - Radnička - Domovinski most te novi putnički terminal Zračne luke Zagreb. Obje bi se osi spajale na jugoistočnu dionicu brze prometnice Zagreb - Sisak, a Aerodromski poslovni centar predstavljao bi stožer urbane kompozicije. Dva paralelna, linearna sustava prostranih parkova zamišljena su kao kralježnica urbanističkog plana kompleksa. Sjeverna i južna paralela, avenije platana i hrastova, oblikovale bi parkovni potez širine $150 \mathrm{~m} \mathrm{u}$ čijem bi se središtu omogućio razvoj Airport Cityja. Taj parkovno-prometni potez započinjao bi na istočnoj priključnoj prometnici i širio se prema zapadu te završavao velikim sportsko-rekreativnim parkom u sastavu druge, okomito postavljene sportsko-zabavne parkovne zone. terminal would become the foundation for urbanisation in the area, directing development towards urban surroundings - especially towards Velika Gorica. The definition of the aforementioned agglomeration would transform itself through the new, complex distribution of urban structures that form along the newly-created green axis that connects the centre of Velika Gorica with the zone of the new passenger terminal. Development in this segment of the tender project was not subject to development in the first phase of airport construction. However, when further development of the airport complex is undertaken in the future, it will have the potential to become the focal point of the urban efficiency of the Zagreb metropolitan area, with strong symbolism and a strong economic effect on the nation and the greater region.

The winning tender project presents the agglomeration of the airport complex as the intersection of two spatial areas: the expansion of Zagreb's commercial zone and the potential of the suburban area of Velika Gorica. As the crossing point of these areas, the new passenger terminal project defined the framework that connects these two important urban axes: Zagreb's central axis from the Upper Town, through Zrinjevac park, across the Liberty Bridge (Most slobode) and through the village of Buzin to the existing airport complex, and Zagreb's new, eastern post-industrial tangent along Heinzelova and Radnička streets, across the Homeland Bridge (Domovinski most) to the new passenger terminal at Zagreb Airport. Both axes would meet at the southeastern part of the Zagreb-Sisak highway, while the airport's business centre would represent the headquarters of the urban composition. Two parallel, linear systems of spacious parts are envisioned as the backbone of the urban plan of the complex. The northern and southern parallels, rows of sycamores and oaks, would border a 150m-wide stretch of park at the centre of which the Airport City could develop. This stretch of park and road would begin at the eastern access road and would stretch towards the west, ending at a large sports and recreation park within a second, 
Ta je zona koncipirana kao ekološka zaštitna zona koja otkriva novo urbano pročelje središnjeg dijela Velike Gorice.

Urbana transformacija ovog područja proizišla iz prožimanja s Airport Cityjem definira visokovrijedni gradotvorni fenomen koji se reflektira u novoj razini urbanosti, sustavu parkova, trgovačkim zonama najviše razine centralnosti, kao i turističkim zonama uz različite sportsko-rekreacijske sklopove. Velika Gorica na taj se način izdvaja kao potentna aglomeracija s važnom prostorno-ekonomskom ulogom u jedinstvenom, upečatljivom prostoru šireg područja grada Zagreba. Unatoč smještaju u prigradskoj zoni grada Zagreba i Velike Gorice, urbanistički koncept novog putničkog terminala Zračne luke Zagreb sagledava prostor u smislu visoke razine urbanosti sa značajnim površinama reprezentativnih, parkovnih poteza i prometnica. Novi orijentiri, fokusi, avenije, parkovi, linearni parkovi, sustav jezera, rekreacijske zone, pješačke oaze, staze te zeleni krovovi sjedinjuju se i stvaraju jedinstveni, urbanističko-arhitektonski koncept. Planirano je također da sustav javnog prijevoza podržava sve prikazane premise urbanističkog plana, a osobito integracijom željezničkog prometa. Kružni željeznički sustav Velika Gorica - Zagreb time bi odredio novi putnički terminal zagrebačke Zračne luke kao polazišnu čvorišnu točku.

Glavno obilježje arhitektonskog rješenja novog putničkog terminala jest njegova urbanost koja se manifestira kroz multidimenzionalne veze, komplementarnosti sadržaja Zračne luke i njezina neposrednog okoliša. Višeslojnost projekta temelji se na bogatstvu i raznolikosti interakcijskih veza postojećeg i novog, prirodnog i umjetnog. Skupina umjetno stvorenih sklopova, s jedne strane, te prirodni okoliš, s druge, predstavljaju elemente sinteze čija su svojstva jasno vidljiva u arhitektonskom rješenju. Pojavljuju se kao konvencionalizirane ideje oblika, predmeta i bića, koje utječu na proces stvaranja arhitektonske forme, što, nakraju, utjelovljuje sve programske i kulturološke parametre te arhitektonske zadaće. sports and entertainment park zone running north to south. This zone is envisioned as an ecologically protection zone that reveals the new urban façade of the central part of Velika Gorica.

The urban transformation of this region arising from its connection with the Airport City is defined by a valuable city-building phenomenon reflected in a new level of urban development, a system of parks, highly centralised commercial zones, and tourist zones with various sports and recreation complexes. This would turn Velika Gorica into a potent agglomeration with an important spatial and economic role in the unified, unique space of the greater Zagreb area. Despite its location in the suburban zone of Zagreb and Velika Gorica, the urban concept of the new Zagreb Airport passenger terminal envisions the space as one with a high level of urban development with significant areas featuring representative stretches of park and roads. New landmarks, focal points, avenues, parks, linear parks, a system of lakes, recreational zones, pedestrian oases, paths, and green roofs merge to form a unified, urban architectural concept. The public transit system is also planned to support all of the portrayed features of the urban plan, especially through integration with rail transit. Thus, the new Zagreb Airport passenger terminal would be defined as the starting point of the Velika GoricaZagreb rail loop.

The main characteristic of the new passenger terminal's architectural design is its urban nature, which is manifested through multi-dimensional connections and the complementarity of the content of the airport and its immediate surroundings. The manifold nature of the project is founded on the richness and diversity of interactive connections between the existing and the new, the natural and the artificial. The group of artificially created complexes in contrast with the natural environment represents elements of a synthesis whose properties are clearly apparent in the architectural design. These elements appear as conventionalised ideal forms, objects, and beings 


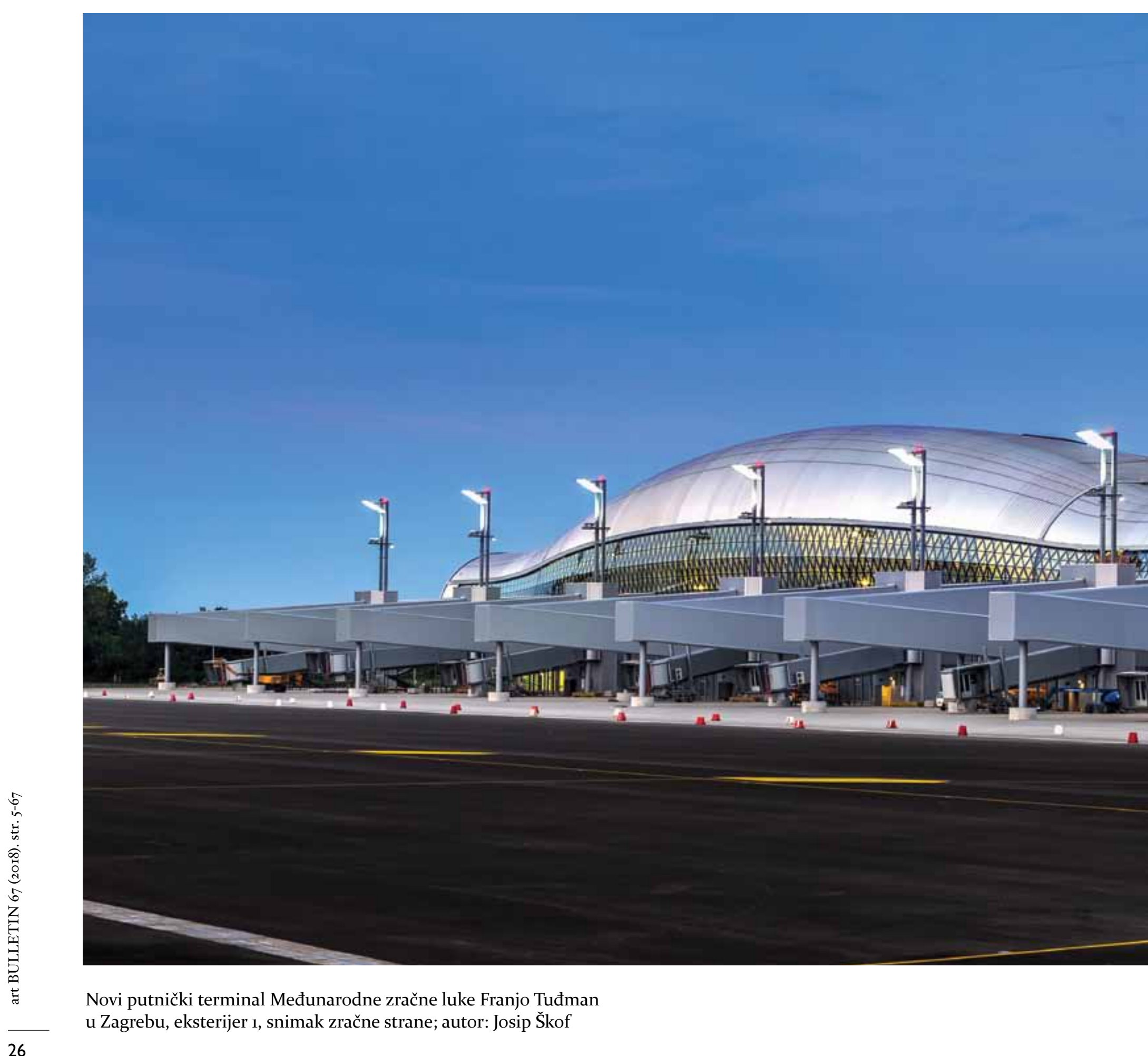




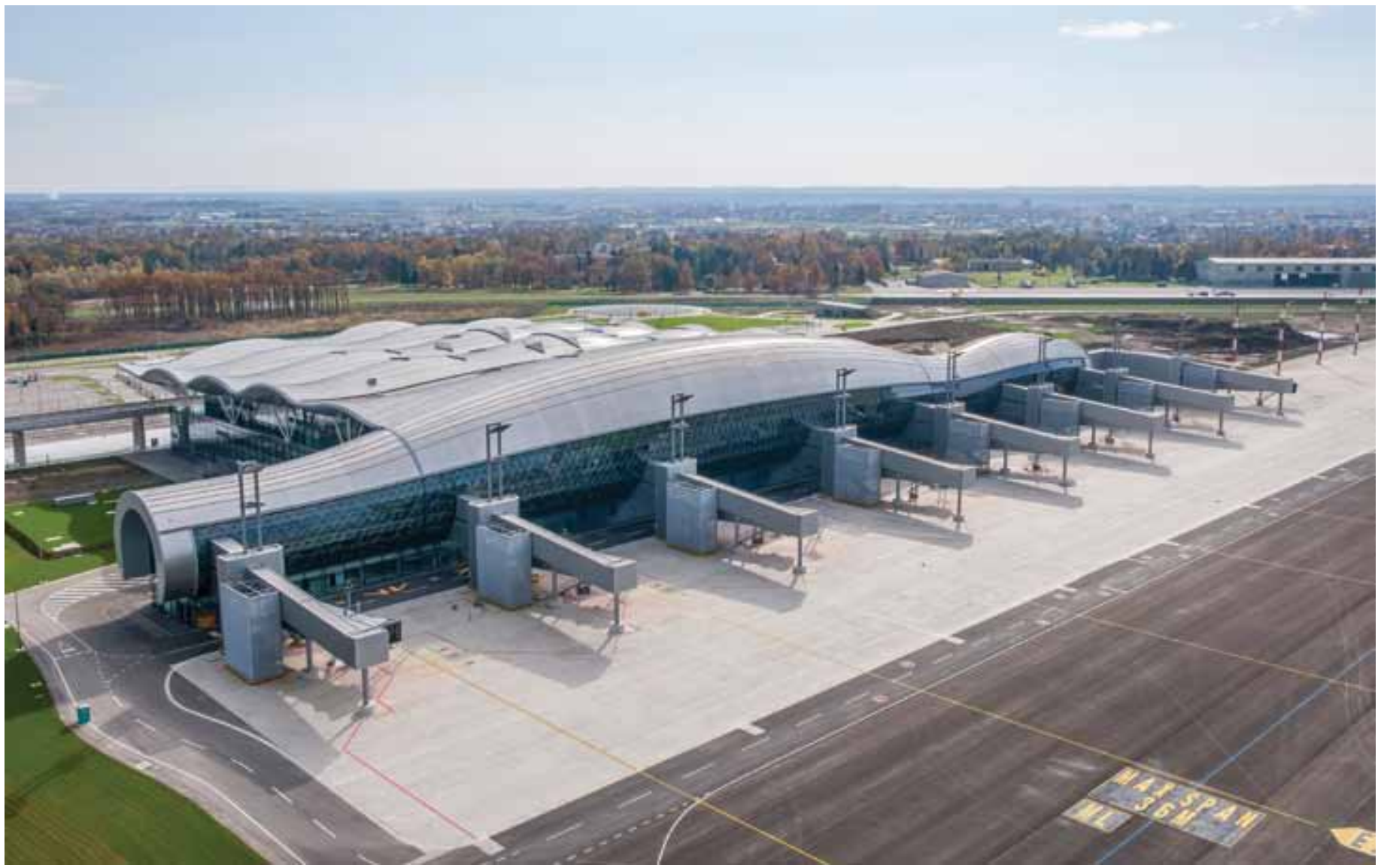

Novi putnički terminal Međunarodne zračne luke Franjo

New Passenger Terminal at Franjo Tudman Tuđman u Zagrebu, eksterijer 2, pogled iz zraka; autor: Studio HRG author: Studio HRG 


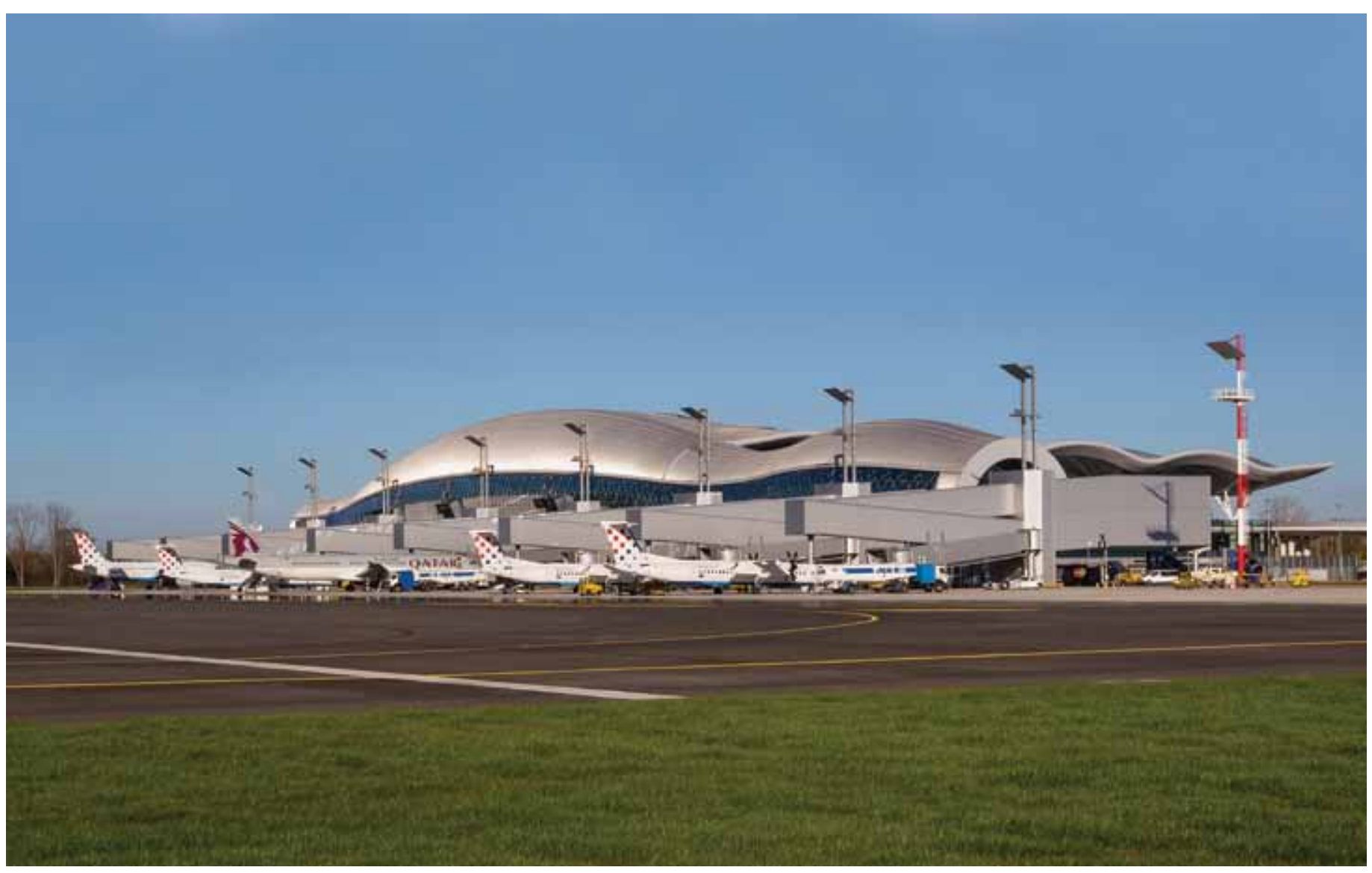

Novi putnički terminal Međunarodne zračne luke Franjo Tuđman u Zagrebu, eksterijer 6; autor: Josip Škof

New Passenger Terminal at Franjo Tudman International Airport Zagreb, exterior 6; author: Josip Škof 


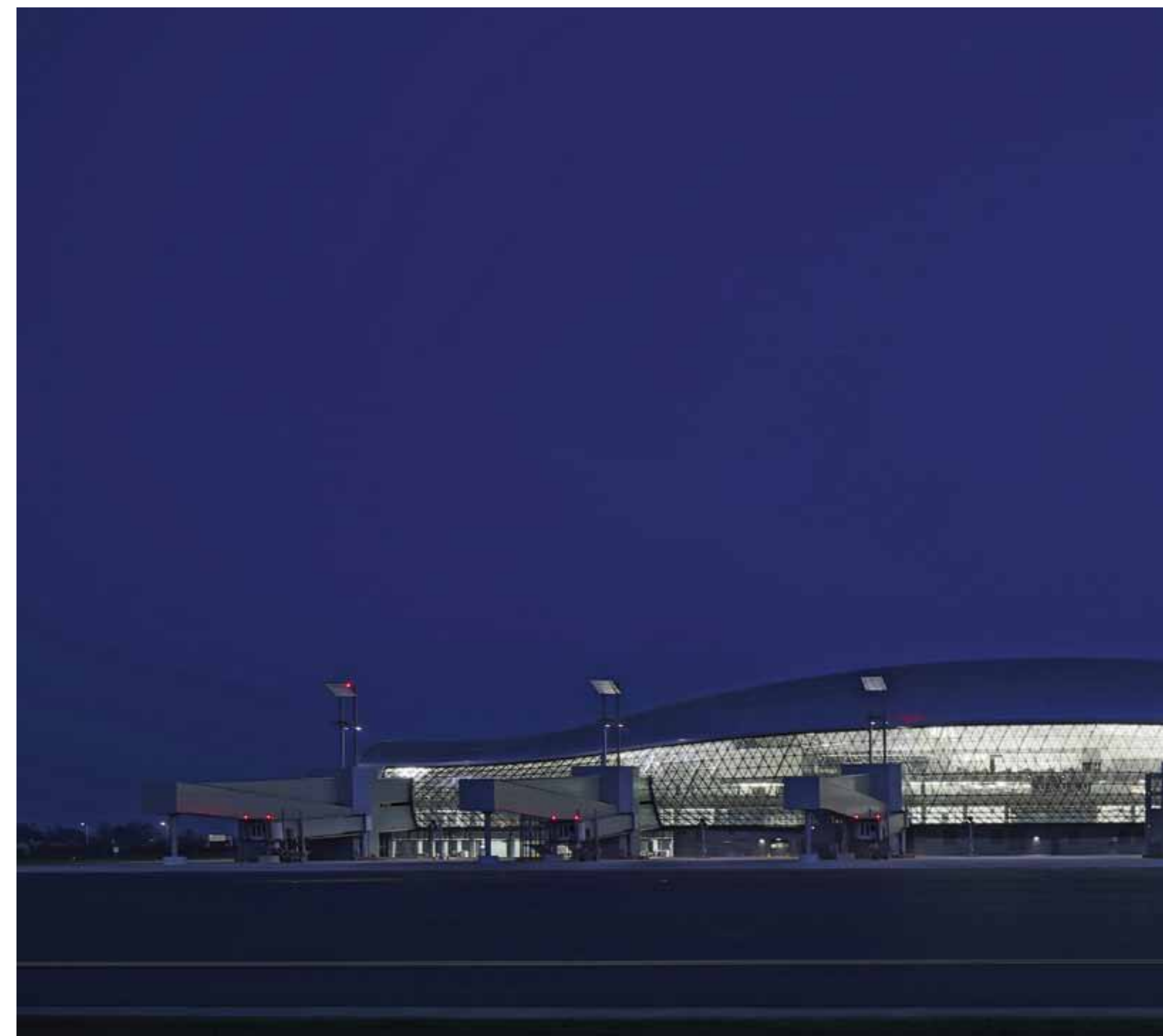

Novi putnički terminal Međunarodne zračne luke Franjo Tuđman u Zagrebu, eksterijer 2; autor: Damir Fabijanić 
Specifična arhitektonska forma građevine postignuta je jedinstvenim spojem estetskih fenomena i funkcionalnih premisa koji spajaju okolišne, simbolične i povijesne paradigme ljudskog razvoja s otvorenošću spram globalnih počela i zatečene lokalne kulture. S jedne strane, stvaranje arhitektonske forme oslanja se na strogo funkcionalnu filozofiju kompleksne strukture terminala, dok je, s druge strane, konačna arhitektonska forma rezultat kompozicije jedinstvenog urbanog krajobraza proizašlog iz kulturnog konteksta.

Takva prostorna harmonija vidljiva je i u interijeru terminala kroz niz različitih, funkcionalno zamišljenih estetskih atrakcija. Lebdeći krov omogućuje maksimalno izlaganje interijera te najširu that influence the process of creating architectural forms, which finally embody all the programmatic and cultural parameters of this architectural task.

The specific architectural form of the building is achieved through a unique combination of aesthetic phenomena and functional premises that connect environmental, symbolic, and historical paradigms of human development with openness to global principles and the extant local culture. On the one hand, the creation of architectural form relies on the strictly functional philosophy of the terminal's complex structure, while the final architectural form is the result of the composition of a unified urban landscape resulting from its cultural context.

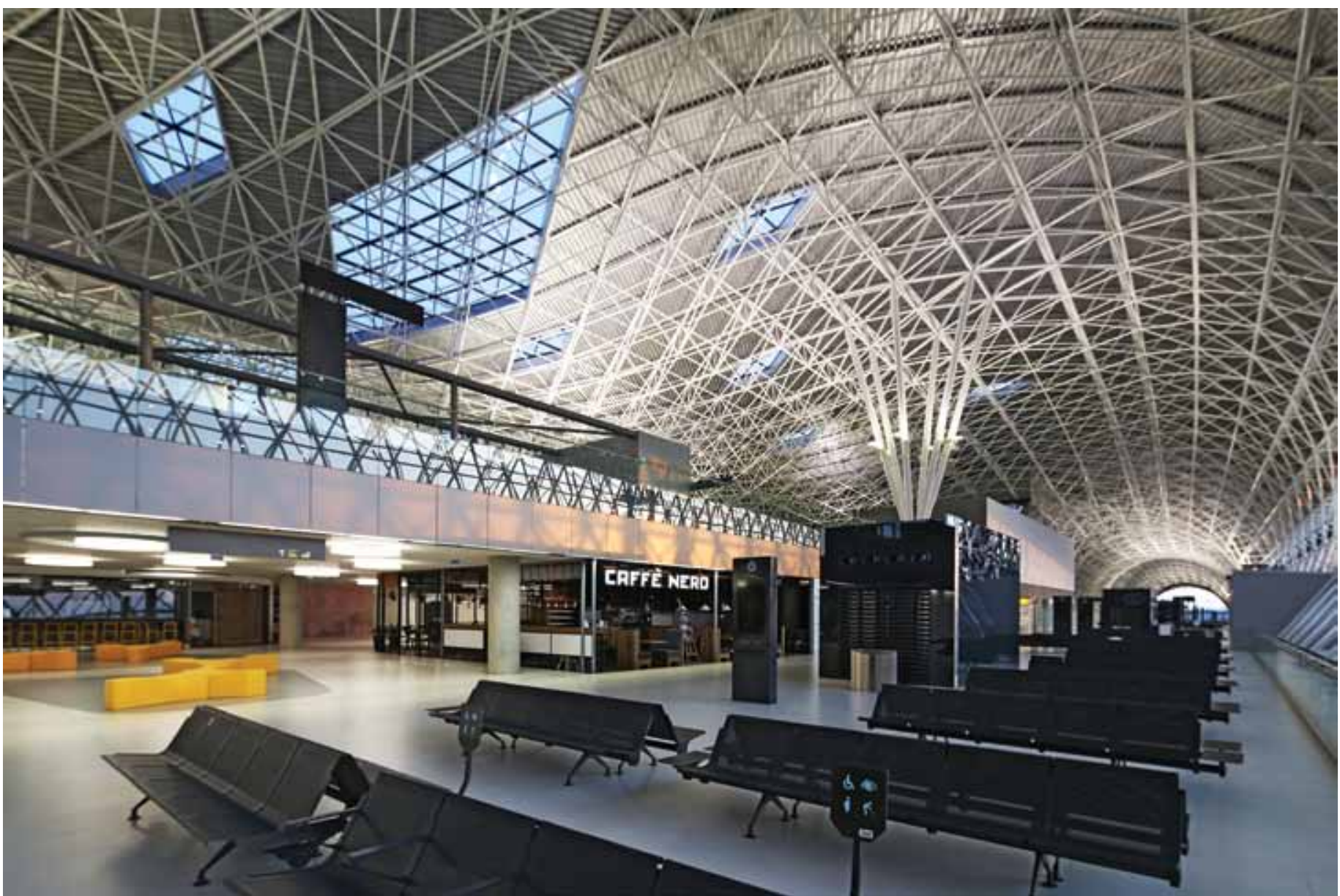

Novi putnički terminal Međunarodne zračne luke Franjo Tuđman u Zagrebu, interijer 1; autor: Damir Fabijanić
New Passenger Terminal at Franjo Tudman International Airport Zagreb, interior 1; author: Damir Fabijanić 
moguću panoramsku orijentaciju spram budućeg Airport Cityja i dinamički strukturiranih sadržaja na prilaznoj strani novog terminala. Neke od spomenutih formalnih arhitektonskih karakteristika, posebno valoviti krov, nadilaze euklidske prostorne paradigme, no nisu lišene strogo utilitarne uloge. Naprotiv, osnovna načela projektiranja temelje se na sveukupnoj racionalizaciji i transparentnosti $\mathrm{s}$ ravnomjernom distribucijom funkcija te s jasnim prostornim okosnicama namijenjenim savršenim obrascima orijentacije putnika.
This spatial harmony is also apparent in the interior of the terminal through a string of different, functionally designed aesthetic attractions. The floating roof allows the interior to be as exposed as possible, also allowing the widest possible panoramic orientation towards the future Airport City and dynamically structured content on the front side of the new terminal. Some of the aforementioned formal architectural characteristics, especially the undulating roof, breach Euclidean spatial paradigms while still retaining a strictly utilitarian role. On the contrary - the basic design principle is founded on general rationalisation and transparency with an even distribution of function, as well as with clear spatial axes intended to serve the perfect forms of passenger orientation.

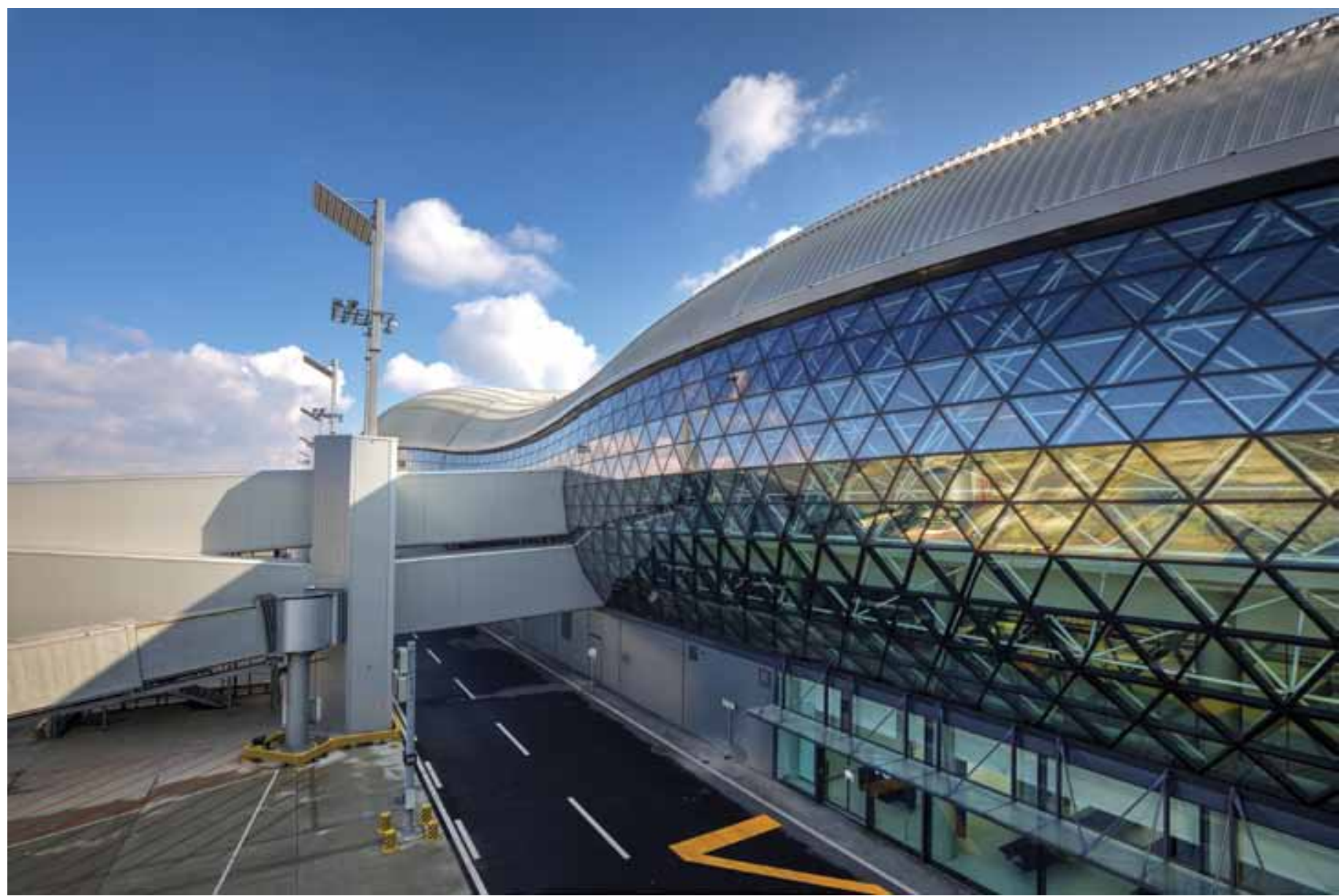

Novi putnički terminal Međunarodne zračne luke Franjo Tuđman u Zagrebu, eksterijer 12, detalj aviomosta; autor: Josip Škof
New Passenger Terminal at Franjo Tudman International Airport Zagreb, exterior 12, jetway detail; author: Josip Škof 


\section{Projektiranje i izgradnja}

Nakon pobjede na međunarodnom natječaju, slijedila je faza razrade projekta. Od samog natječaja do konačne realizacije proteklo je više od osam godina, a projektiranje i realizacija prolazili su kroz šest godina recesije, što ima za posljedicu provođenje racionalizacije, neprestano usklađivanje projekta s gospodarskim uvjetima, izmjenama i dopunama zakona i s promjenama izvedbenih projekata te usuglašavanje s projektima sigurnosnog karaktera (bomb blast study, britanski standardi za požarnu zaštitu i sl.). Specifični način projektiranja i sistematizacije projektne dokumentacije, prema zahtjevu investitora, uz nadzor nezavisnog inženjera (Arup) te ocjena svake faze i njezinih dijelova rezultirali su s više od 640 pozitivno ocijenjenih dijelova projekta, što je bio maksimum.

Projektnu dokumentaciju izradile su tvrtke Kincl d.o.o., Neidhardt arhitekti d.o.o. i IGH pro-
Novi putnički terminal Međunarodne zračne luke Franjo Tuđman u Zagrebu, interijer 1; prostorija za check-in; autor: Josip Škof

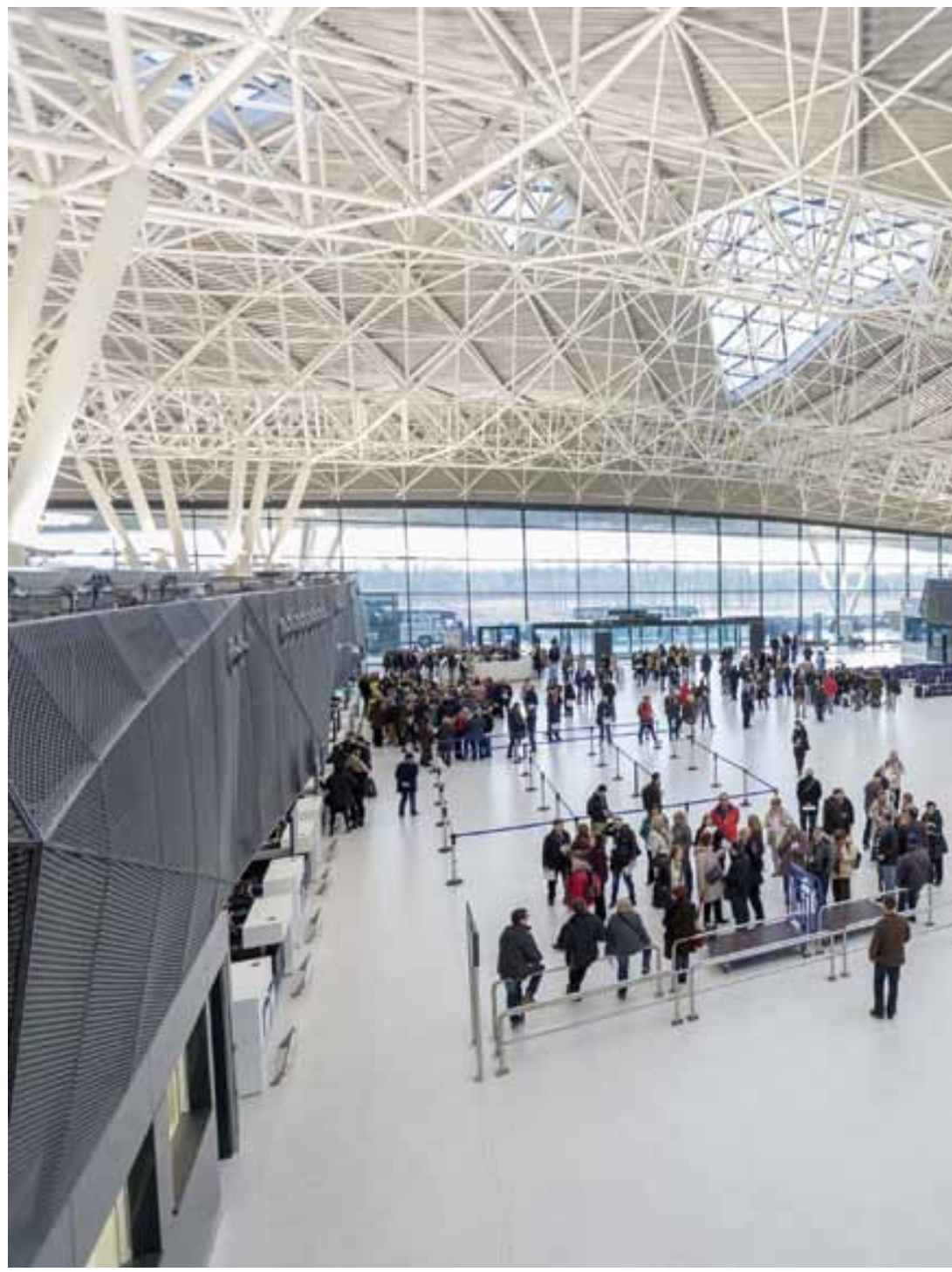




\section{Design and construction}

New Passenger Terminal at Franjo Tudman International Airport Zagreb, interior 1, check-in hall; author: Josip Škof

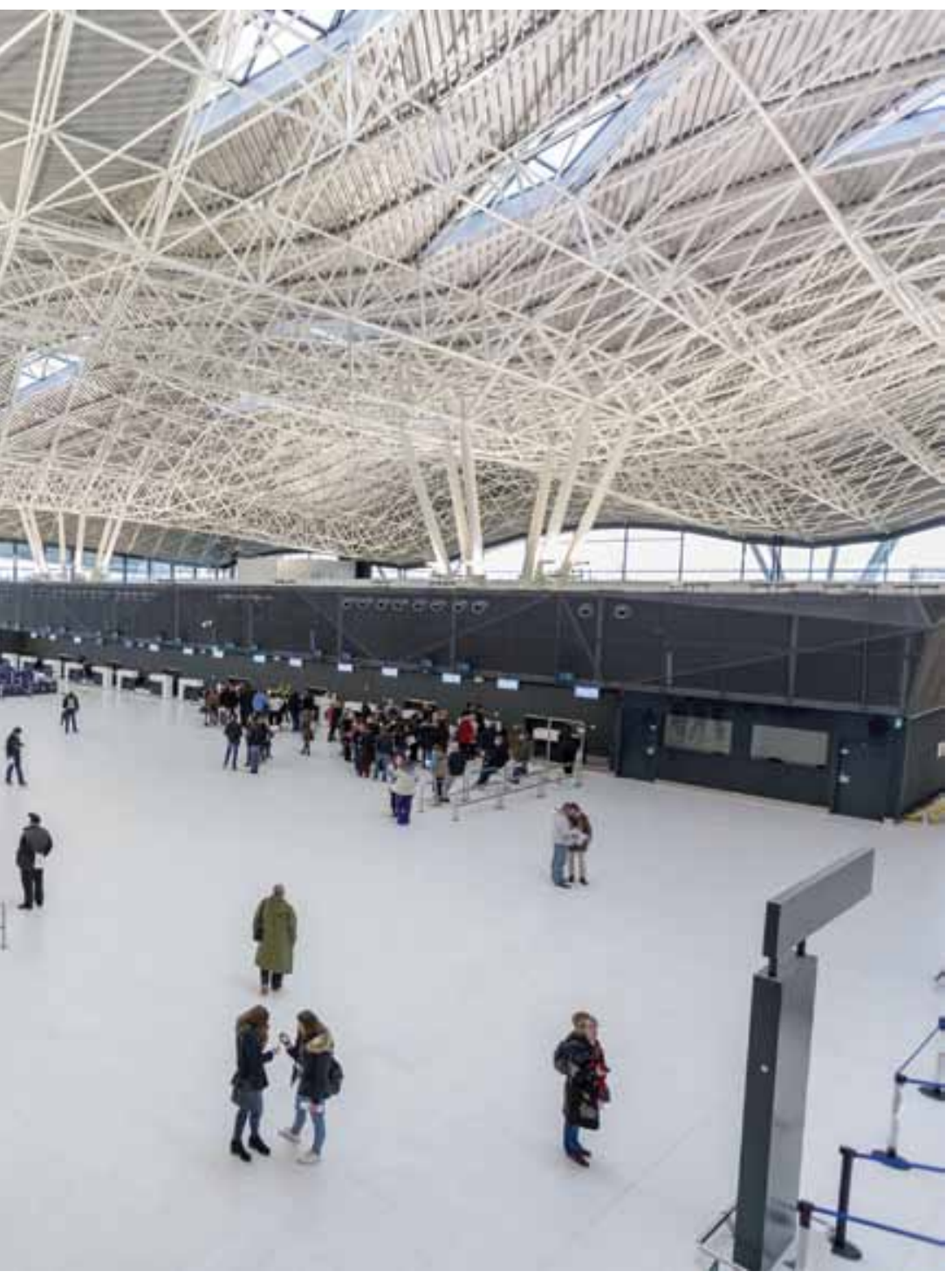

After winning the international tender, the project development phase began. More than eight years passed between the tender and the project's completion; the design and construction took place during six years of recession, which resulted in rationalisation, constant adjustment of the project with economic conditions, amendments to laws, changes in detailed designs, and harmonisation with projects regarding security (bomb blast study, British fire protection standards, etc.). The specific manner of design and systematisation of the project documentation according to the demands of investors, under supervision from an independent engineer (Arup) and with a rating of each phase and its details, resulted in more than 640 positively rated project segments, which was the maximum possible.

The project documentation was created by Kincl d.o.o., Neidhardt arhitekti d.o.o, and IGH projektiranje d.o.o. on the basis of design agreements with the concessioner, Međunarodna zračna luka Zagreb d.d. and in cooperation with the architectural team: Ana Breka, Mirta Dropuljić, Ivana Drviš, Almir Ibrahimović, Igor Janković, Zrinka Mustać, Mihovil Selak, Ivana Benković, and numerous experts from renowned firms such as $\mathrm{Vi-}$ adukt, Kamgrad, KFK Tehnika, Zagreb Montaža, 
tektonski koncept i oblikovanje prvonagrađenog natječajnog rada zadržani su u koncesijskim dokumentima u cijelosti. Unatoč problemima koji su uobičajeni pri realizaciji, uspješno se ostvarila arhitektonska ideja koju krasi originalnost temeljena na ideji organičnosti - osnovnom postulatu arhitektonskog koncepta.

Koncesionar je započeo s izgradnjom novog putničkog terminala Zračne luke Zagreb 2013. godine na djelomično izgrađenom prostoru koji je u većem dijelu bio u nadležnosti Ministarstva obrane Republike Hrvatske, dok su manji dio predstavljale privatne čestice. U konačnici, novi je kompleks za javnost otvoren 28. ožujka 2017. kao 1. etapa izgradnje, pri čemu će se s izgrađenih $65.000 \mathrm{~m} 2$ prostora služiti do 5 milijuna putnika godišnje.
CTP Projekt, Connecto Projekt, Telektra, SBS, etc. The architectural concept itself and the design of the winning project are fully contained in the concession documents. Despite usual problems during construction, this architectural idea was successfully realised, characterised by originality founded in organicness as the basic postulate of its architectural concept.

The concessionaire began building the new Zagreb Airport passenger terminal in 2013; the majority of the land it was built upon fell under the jurisdiction of the Croatian Ministry of Defence, while a small portion was privately owned. Finally, the new complex was opened to the public on 28 March 2017 as the first phase of construction; its $65, \mathrm{ooom}^{2}$ of space can serve up to 5 million passengers per year.

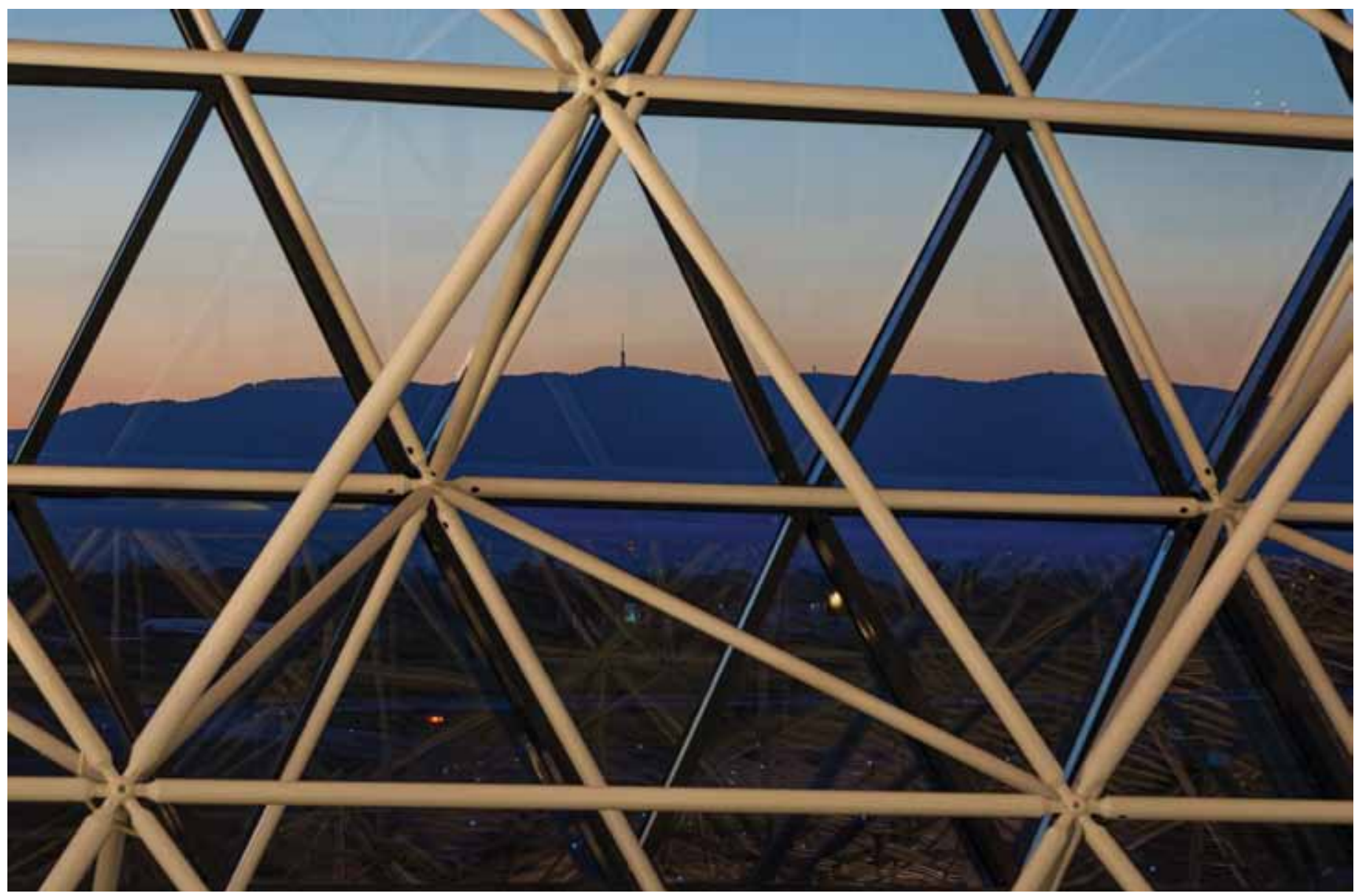

Novi putnički terminal Međunarodne zračne luke Franjo Tuđman u Zagrebu, interijer 16; autor: Josip Škof
New Passenger Terminal at Franjo Tudman International Airport Zagreb, interior 16; author: Josip Škof 


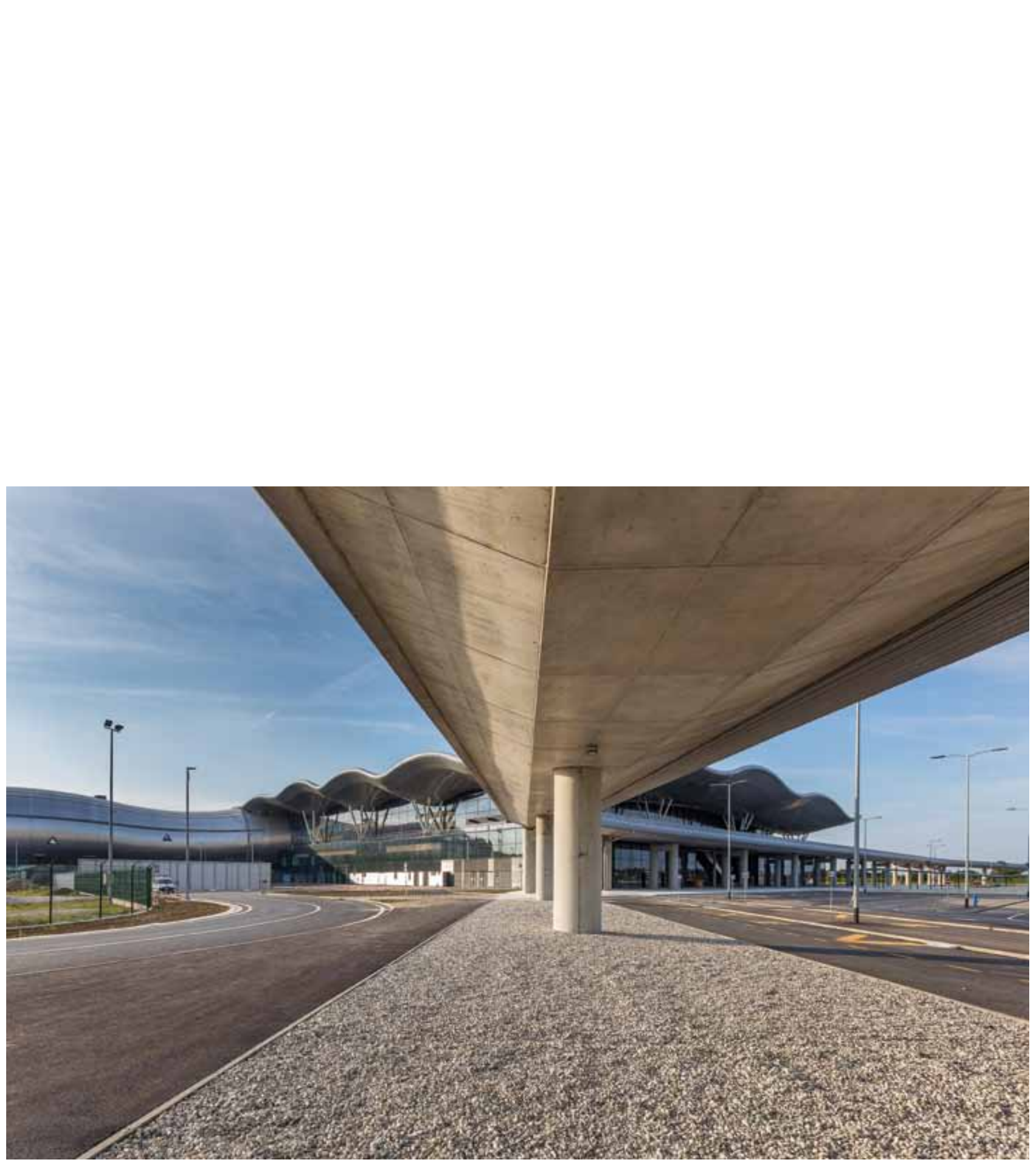

Novi putnički terminal Međunarodne zračne luke Franjo Tuđman u Zagrebu, eksterijer 5; autor: Josip Škof
New Passenger Terminal at Franjo Tudman International Airport Zagreb, exterior 5; author: Josip Škof 


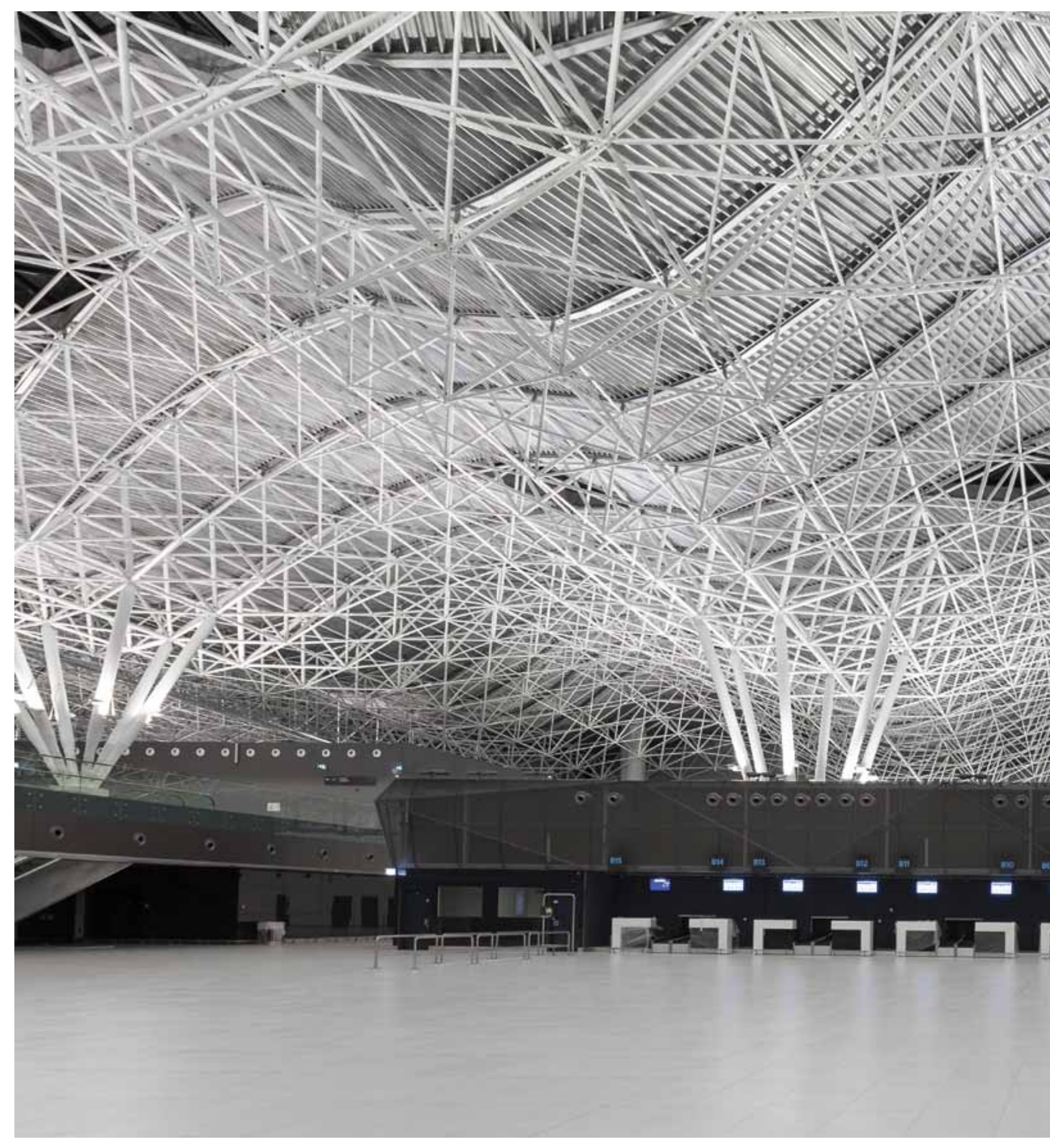

Novi putnički terminal Međunarodne zračne luke Franjo Tuđman u Zagrebu, interijer 2; autor: Josip Škof 


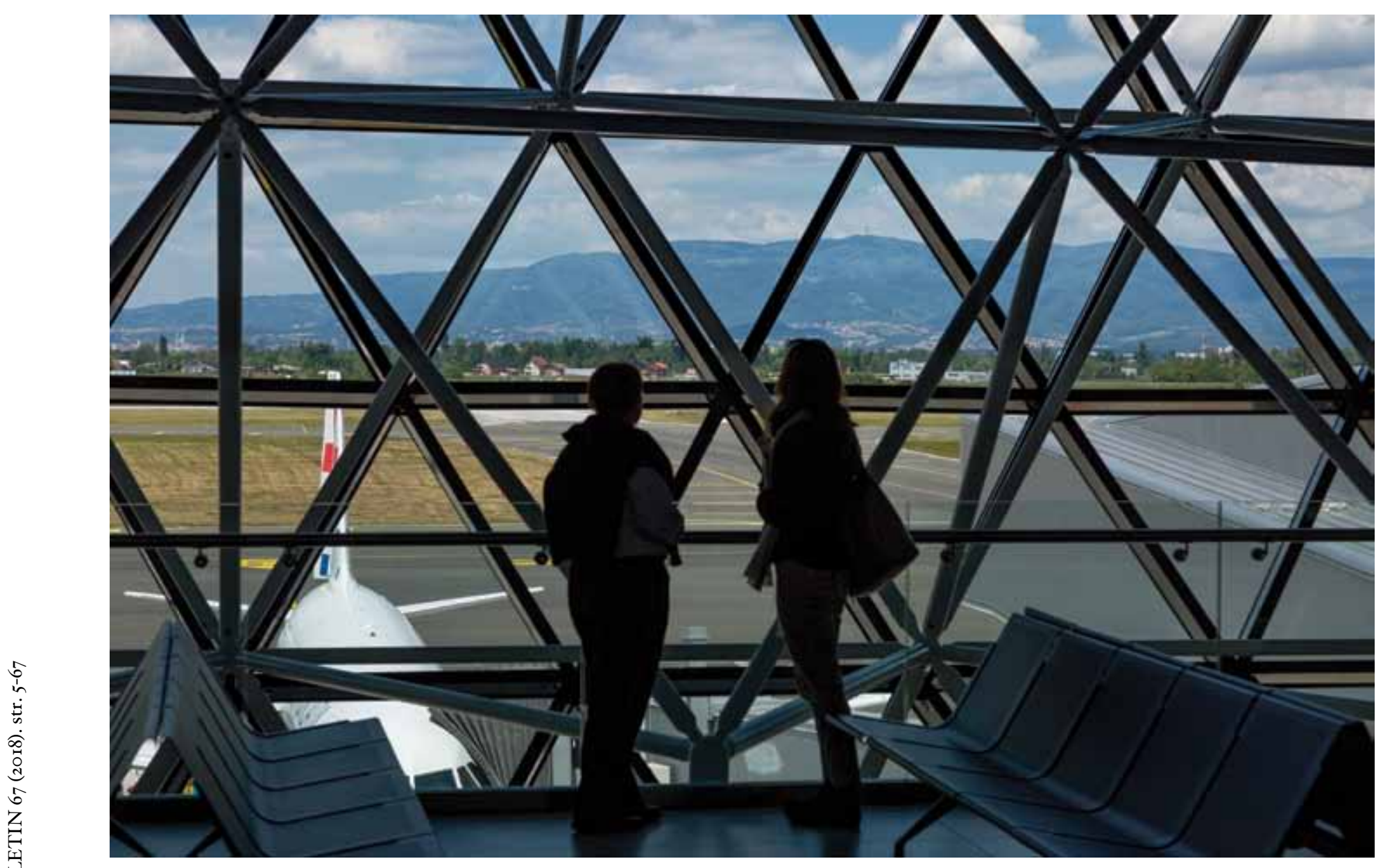

Novi putnički terminal Međunarodne zračne luke Franjo Tuđman u Zagrebu, interijer 5, pogled s izdanka; autor: Josip Škof
New Passenger Terminal at Franjo Tudman International Airport Zagreb, interior 5, view from the pier; author: Josip Škof 


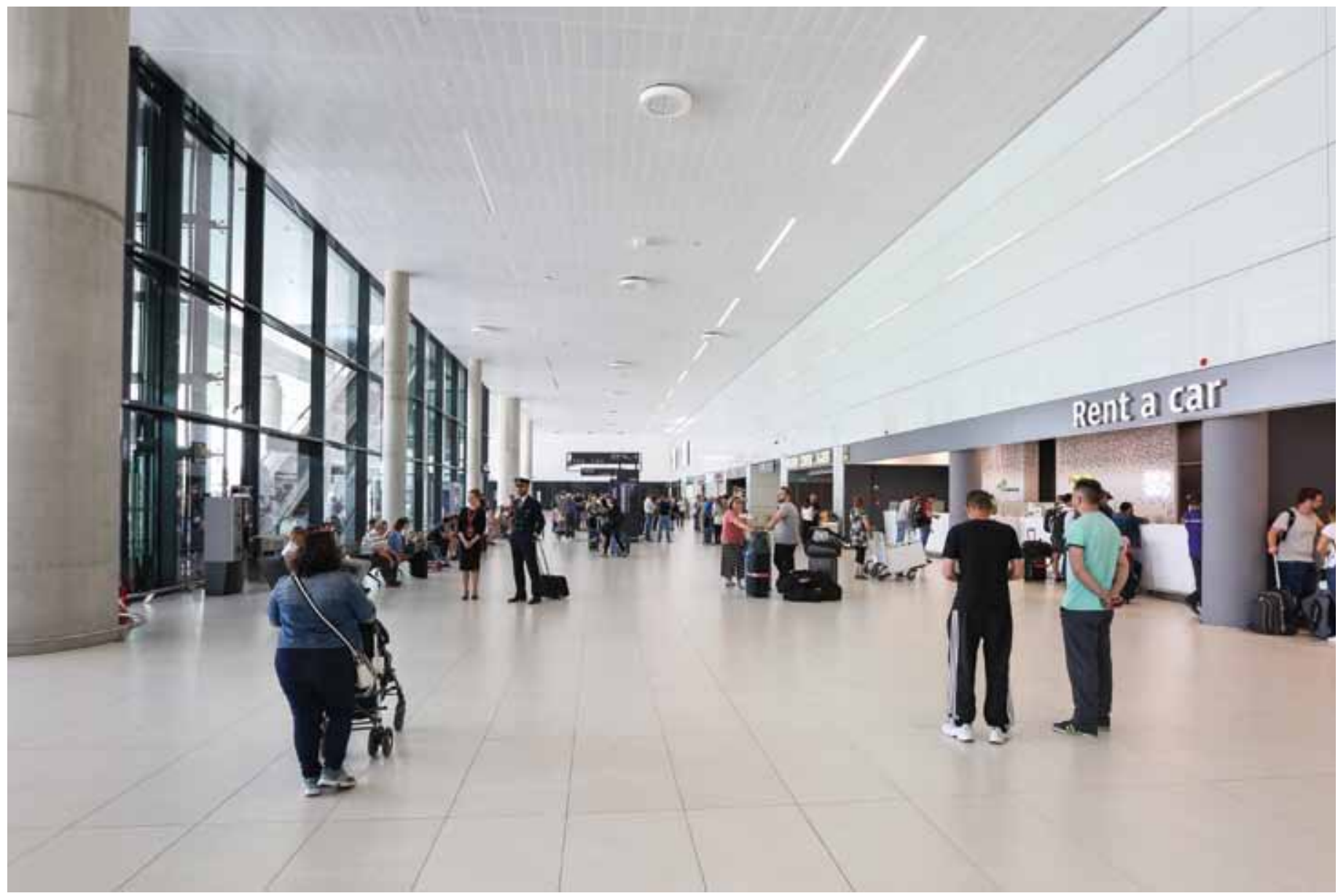

Novi putnički terminal Međunarodne zračne luke Franjo Tuđman u Zagrebu, interijer 15; autor: Josip Škof

New Passenger Terminal at Franjo Tudman International Airport Zagreb, interior 15; author: Josip Škof 
Novi putnički terminal Međunarodne zračne luke Franjo Tuđman u Zagrebu, interijer 2; autor: Damir Fabijanic

New Passenger Terminal at Franjo Tudman International Airport Zagreb, interior 2; author: Damir Fabijanić

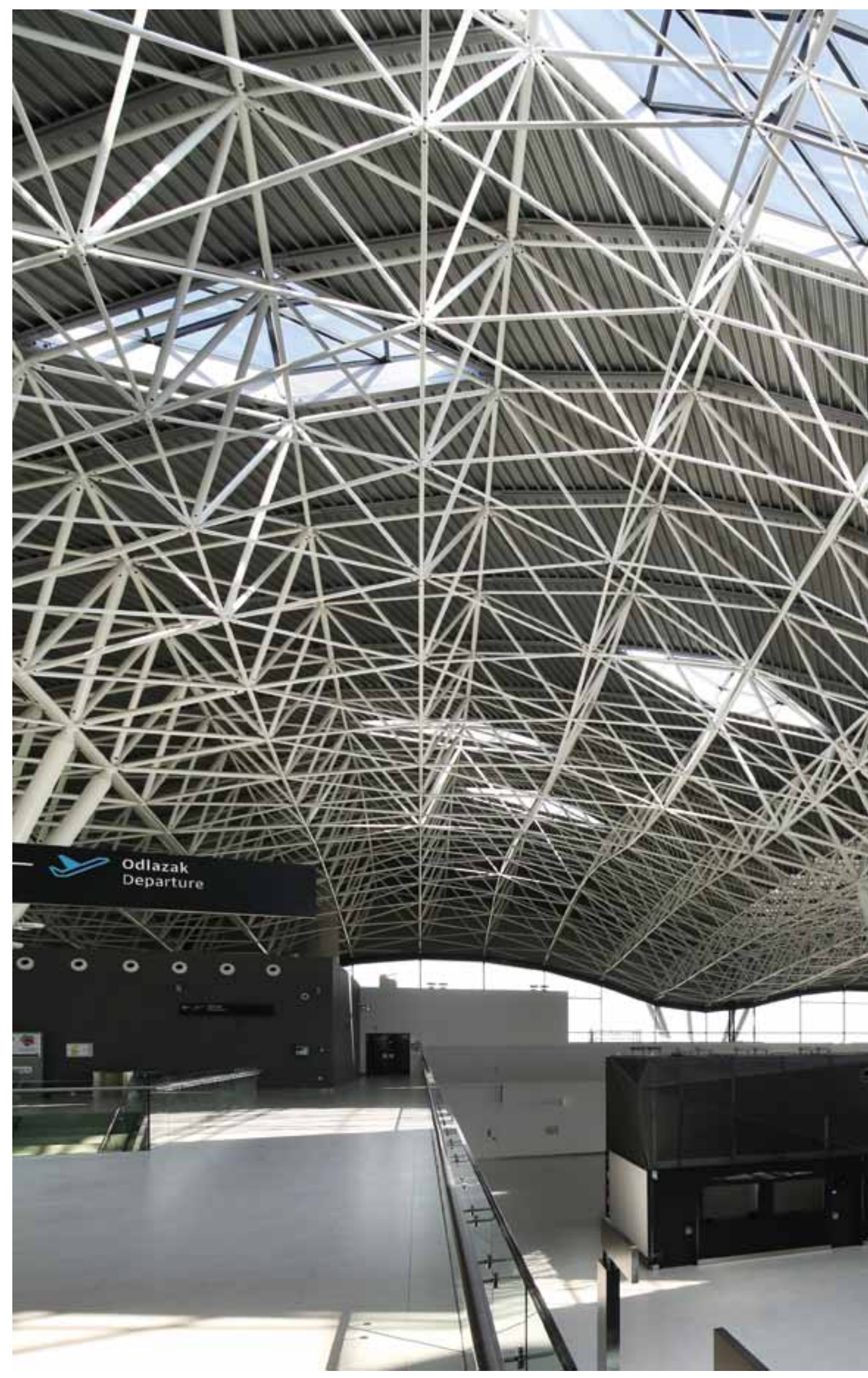




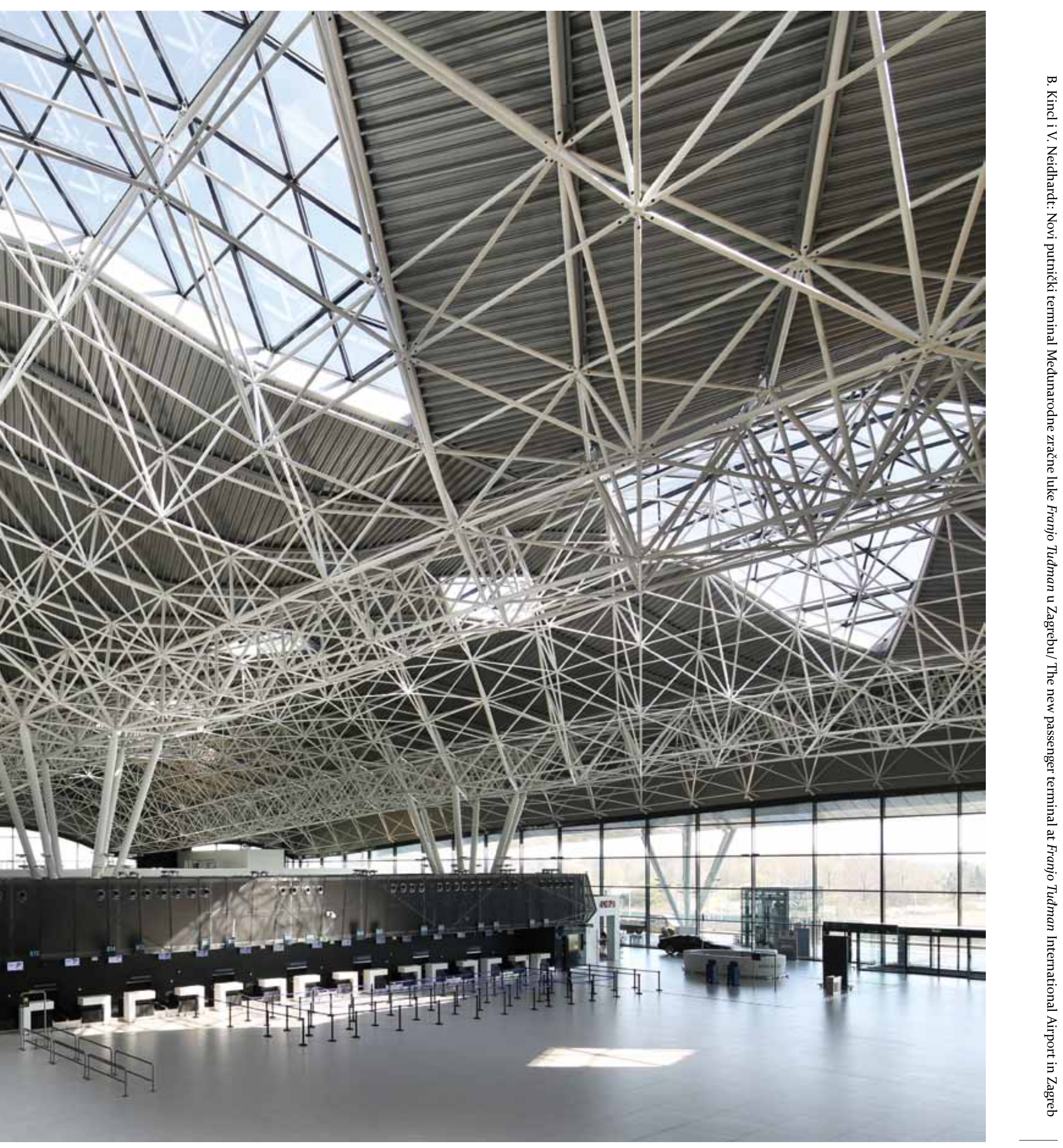




\section{Prostorna organizacija}

Projekt novog putničkog terminala Zračne luke Zagreb obuhvaćao je sljedeće površine i objekte manevarsko-operativne funkcije: novu zgradu putničkog terminala, novu stajanku, nove vozne staze, novu brzu voznu stazu za izlaz, parkirališta te pristupne i servisne prometnice sa zračne i zemaljske strane.

Prometno rješenje pristupa terminalu temelji se na Prostorno-prometnoj studiji cestovno-željezničkog prometa šireg područja grada Zagreba (IGH Zagreb, 2009.). Glavna prilazna prometnica aerodromu spojena je na istočnu obilaznicu Velike Gorice kojom se zatim dolazi do autoceste $\mathrm{A}_{3}$ (obilaznice Zagreba) i čvora Kosnica. Uz glavnu pristupnu prometnicu izgrađene su i prometnice sa zemaljske strane NPT-a: pristupna prometnica s dva kružna raskrižja kojima se promet usmjerava prema zgradi novog putničkog terminala i parki-
Novi putnički terminal Međunarodne zračne luke Franjo Tuđman u Zagrebu, interijer 2o; autor: Josip Škof

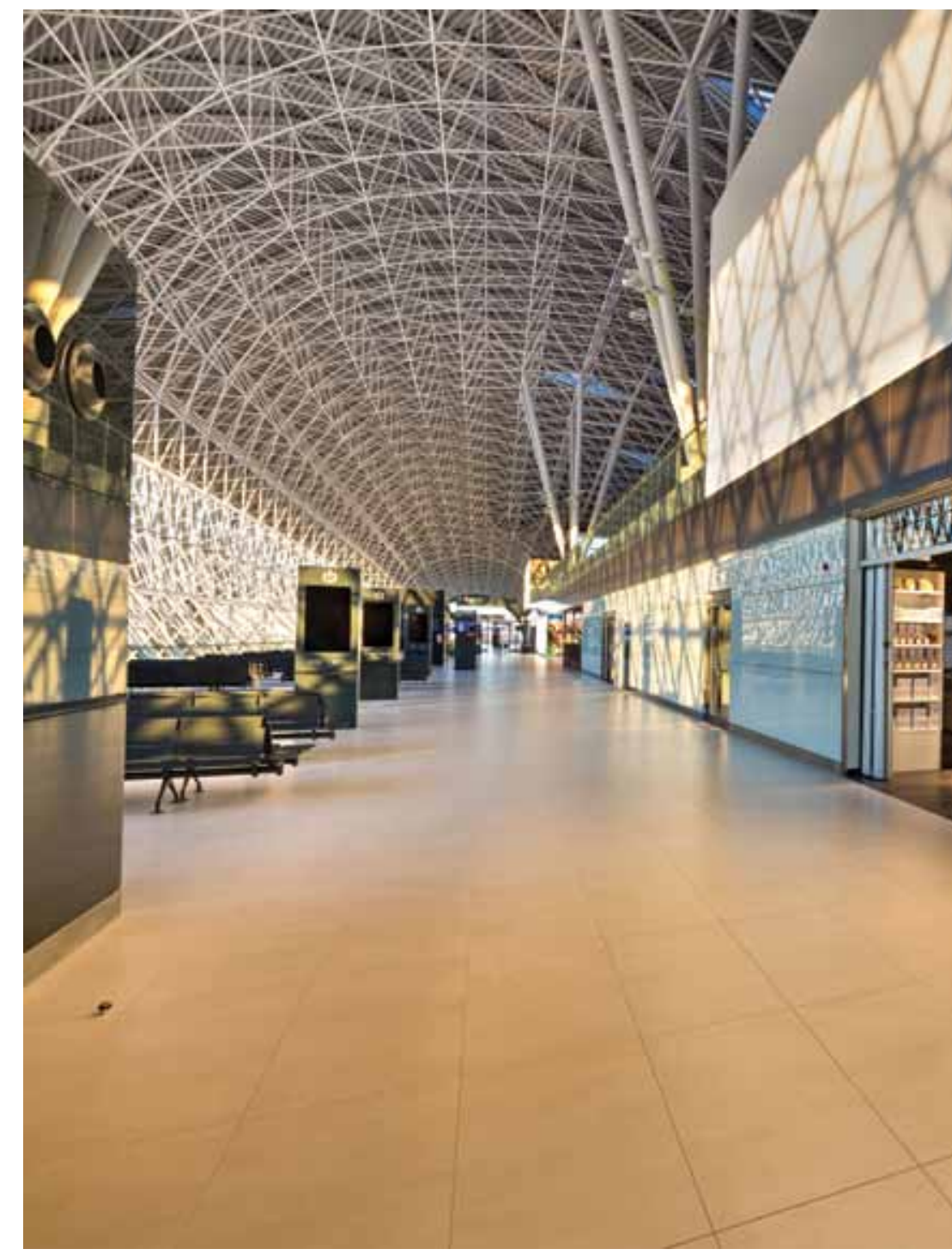




\section{Spatial organisation}

New Passenger Terminal at Franjo Tudman International Airport Zagreb, interior 20; author: Josip Škof

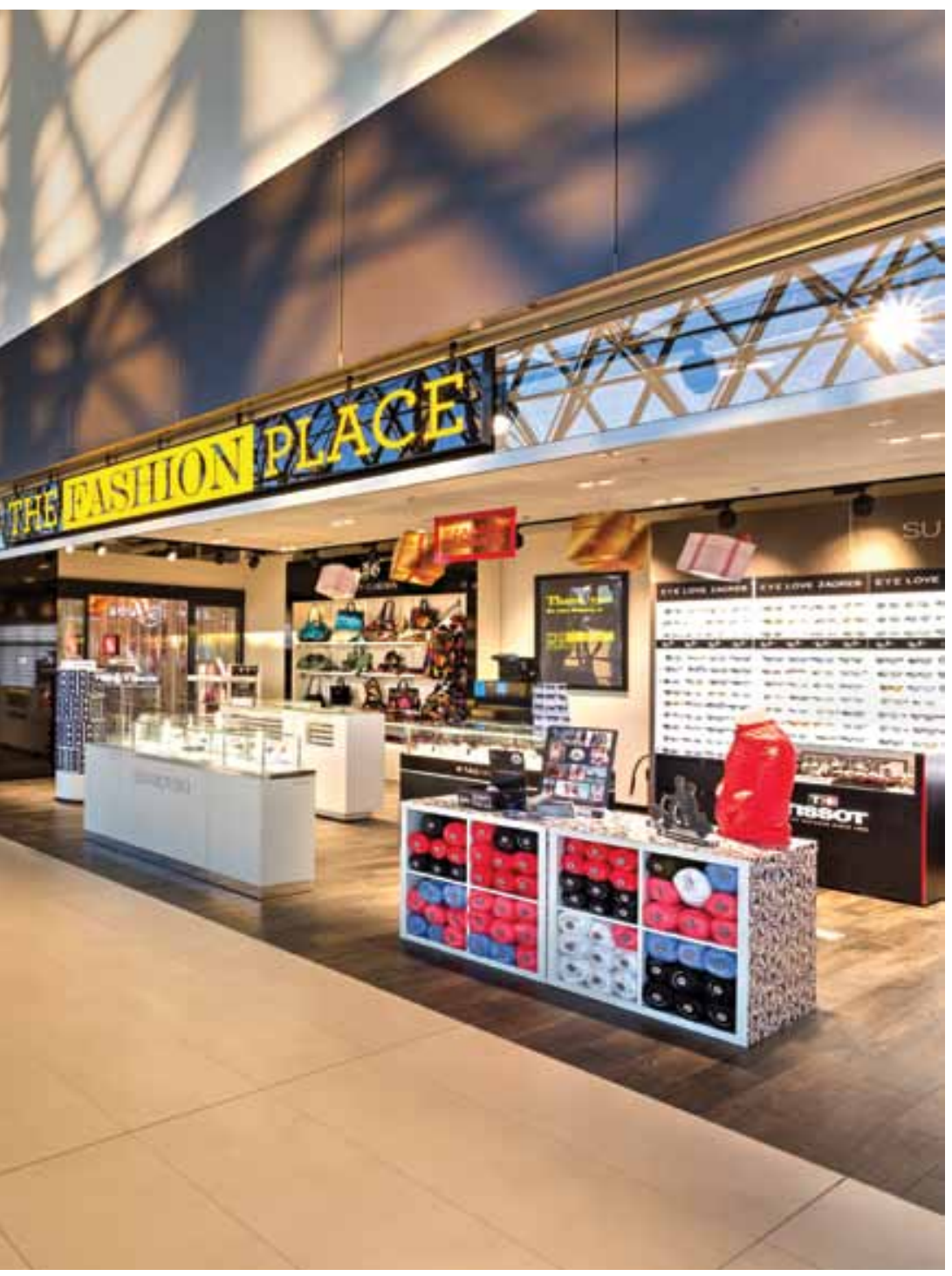

The new Zagreb Airport passenger terminal project encompassed the following areas and manoeuvring space: the new passenger terminal building, a new apron, new taxiways, a new fast runway access taxiway, parking lots, and service roads on both the airport and ground side.

The transport design for approach to the terminal is based on the Spatial and Traffic Study of Road and Rail Traffic in the Greater Zagreb Area (IGH Zagreb, 2009). The main approach road to the airport is connected to the eastern Velika Gorica bypass, which then leads to the $\mathrm{A}_{3}$ highway (Zagreb bypass) and the Kosnica interchange. In addition to the main approach road, roads on the landside area of the new passenger terminal have also been built: an approach road with two roundabouts that direct traffic towards the new passenger terminal building and parking areas, as well as landside service roads alongside the very edge of the terminal building plot. Pedestrian and cycling lanes have also been included in the profile of the roads.

The spatial organisation of the main approach to the building is characterised by a dominant central pedestrian area - a "promenade" bordered by the arrival and departure ramps and the approach road, which together constitute a trap- 


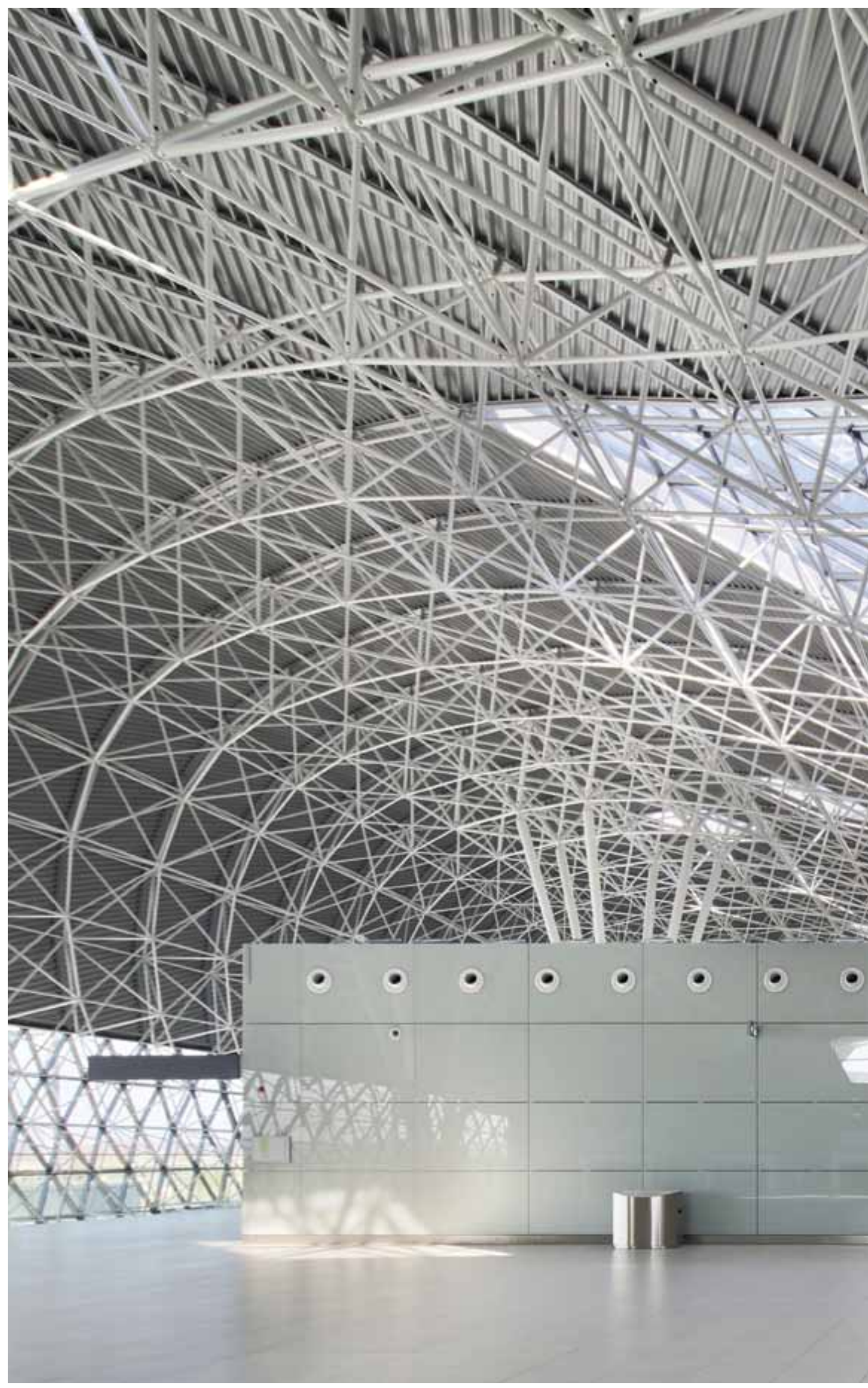




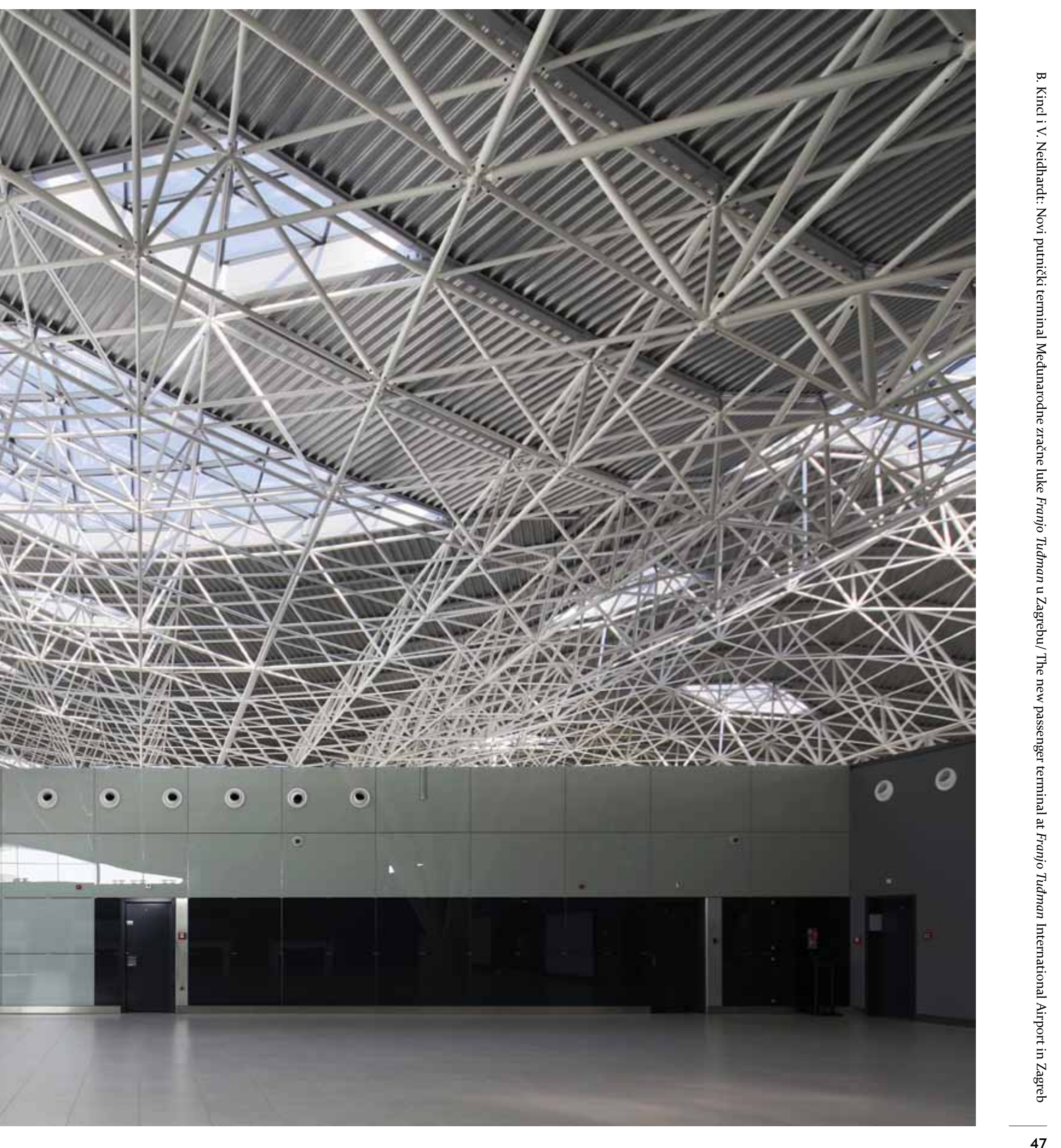


smješteno je parkiralište za osobna vozila, dok se na zapadnoj strani nalaze parkirališta zaposlenih, stajališta autobusa i taksija te kompleks i parkiralište za rent-a car vozila. Energana kompleksa smještena je na izdvojenoj lokaciji zapadno od objekta terminala, gdje je smješten i ulaz za zaposlene i gospodarska vozila. Cjelokupan je prostor, zbog sigurnosnih zahtjeva, striktno podijeljen na dvije zone: airside - zračna strana i landside - zemaljska strana.

Prva etapa izvedbe zgrade terminala sastoji se od centralne aerodromske zgrade s izdancima (engl. piers) povezanima s osam aviomostova sa sjeverne strane te dolazno-odlaznom rampom s vijaduktom za vozila s južne strane. Sam vijadukt projektiran je tako da se omogući širenje aerodromske zgrade prema istoku, kada kapacitet Zračne luke prijeđe 5 milijuna putnika, a izdanci su planirani na način koji omogućuje produljenje prema istoku i zapadu na 10, 12 pa sve do 15 aviomostova, sukladno rastu broja putnika.

Zgrada novog putničkog terminala Zračne luke Franjo Tuđman u Zagrebu veličine je 153 m x 153 $\mathrm{m}$, duljine izdanaka iznose $284 \mathrm{~m}$, visine do $35 \mathrm{~m}$, a ukupna površina $65.000 \mathrm{~m}^{2}$, u kojoj su na četiri etaže raspoređeni prostori za obradu putnika i prtljage te propisani komplementarni sadržaji vezani za putovanja avionom, pri čemu su glavne javne razine zemaljske strane terminala - prizemlje i drugi kat - međusobno povezane vanjskim eskalatorima i dizalima smještenima na samom ulazu u zgradu te setovima dizala i servisnih stepenica u komunikacijskim jezgrama.

U prizemlju su, osim glavnog dolaznog hala, smješteni prostori obrade i preuzimanja prtljage te, na krajevima izdanaka, čekaonice s izlazima koji su autobusnim vezama povezani sa stajankama. Tu se nalaze i komplementarni sadržaji kao što su ugostiteljstvo, bankomati, rent-a-car, naplata parkiranja, Turistički informativni centar grada Zagreba, sanitarni čvorovi i sl.

Prvi kat - dolazna etaža / etaža transfera - pruža putnicima u dolasku prvi uvid u terminal, prije ezoid. On the eastern side of the zone edged by these roads, there is a parking lot for personal vehicles, while the employee parking lots, bus stops, taxi stands, and rent-a-car complex and parking lot are all located on the western side. The power plant for the complex is located at a separate location west of the terminal building, where the employee and commercial vehicle entrances are also located. Due to security demands, the entire area is divided into two zones: the airside area and the landside area.

The first stage of terminal building construction consists of the central airport building with piers connected with eight jetways on the northern side and an arrival and departure ramp with a viaduct for automobile traffic on the south side. The viaduct itself was designed to allow the expansion of the airport building towards the east when the airport's capacity grows to more than 5 million passengers, and the piers are planned such as to allow extension towards the east and west to 10,12 , and up to 15 jetways in accordance with the increase in the number of passengers.

The new passenger terminal at Franjo Tuđman Airport in Zagreb is $153 \times 153 \mathrm{~m}$ in size, the piers are $284 \mathrm{~m}$ long and up to $35 \mathrm{~m}$ high, and the total surface area is $65,0^{000 m^{2}}$, within which spaces for passenger and luggage processing are located across four floors. The building also contains required complementary facilities related to air travel; the main public levels on the landside area of the terminal - the ground floor and first floor - are interconnected with the external escalators and lifts located at the very entrance to the building, as well as with sets of lifts and service stairs in the halls connecting functional spaces.

On the ground floor, in addition to the main arrivals hall, there are spaces for luggage handling and processing; waiting rooms with exits connected by bus to the aprons are located at the ends of the piers. There are also complementary facilities such as food and beverage outlets, cash points, rent-a-car services, parking payment points, a Za- 
silaska u dolazni hal i preuzimanje prtljage. Tu su smješteni razni sadržaji vezani na sigurnost zračnog putovanja, kao što su sigurnosne kontrole $\mathrm{i}$ kontrole putovnica, službe centralnog nadzornog sustava aerodroma, zdravstvene kontrole i granične policije, sigurnosni pregled u transferu itd.

Na drugom katu smješten je odlazni hal s 30 check-in pultova u prvoj fazi, dok je u konačnici planirano 6o takvih mjesta. Tu je smješteno i 12 self-check-in mjesta, kojih će u konačnici biti 24, centralni informacijski pult, lokali, duhovni prostor, check-in za odlaganje velike prtljage itd.

Nakon prijave na let, putnici se upućuju na treći kat. Tamo su smješteni prostori sigurnosne kontrole, nakon koje se promet putnika dijeli na domaći i međunarodni, uz obveznu kontrolu putovnica u međunarodnom prometu. Slijedi spuštanje putnika na odlaznu razinu izdanaka, gdje se nalaze čekaonice, prostori lokala, restorana, duty-free trgovine, CIP salon za poslovne putnike (commercially important people) te odlazni gateovi.

Osnovna načela projektiranja terminala temeljena su na sveukupnoj racionalnosti i ravnomjernoj distribuciji funkcija te integralnosti u procesu s jasnim prostornim okosnicama kako bi se dostigao neupitni obrazac arhitektonske originalnosti. greb Tourist Information Centre, toilets, etc.

The first floor - the arrivals / transfer floor offers arriving passengers their first view of the terminal before they reach the arrivals hall and baggage claim. Various facilities related to air travel security are located here, such as security checkpoints and passport control, central airport surveillance system services, health services and border police, security checks for transfers, etc.

The departures hall is located on the second floor; it features 30 check-in counters in the first phase, although 6o are planned for the final phase. There are also 12 self-check-in kiosks ( 24 are foreseen for the final phase), a central information desk, food and beverage outlets, check-in for oversized luggage, etc.

After checking in for their flight, passengers are directed to the third floor. This area features security checkpoints, after which passenger flow is divided into domestic and international with compulsory passport checks for international passengers. After this, passengers descend to the departures level of the piers, where they will find waiting rooms, cafés, bars, restaurants, duty-free shops, a CIP (commercially important people) salon, and departure gates.

The basic principles of the terminal's design are founded in the general rationalisation and even distribution of function, as well as process integration with clear spatial axes in order to achieve an unquestionable form of architectural originality. 


\section{Oblikovanje}

Novi putnički terminal Međunarodne zračne luke Franjo Tuđman u Zagrebu, interijer 18; autor: Josip Škof

Arhitektonska forma novog putničkog terminala Zračne luke Franjo Tuđman u Zagrebu generirana je jedinstvenim pretapanjem estetskih fenomena i funkcionalnih zadaća. Ostvaruje se u kombinacijama analogija kontekstualno-okolišnih, simboličkih i povijesnih paradigmi kulturnoga razvoja s potpunom otvorenošću prema univerzalnosti globalnih te jedinstvenosti lokalnih kulturnih obrazaca. Manipulacija obilježjima/ atributima duha mjesta u procesu dizajniranja ostvarena je arhitektonskim oblikom koji nosi značajke jasnog odnosa s kontekstom. S jedne strane, arhitektonska forma počiva na striktnoj funkcionalnoj filozofiji kompleksne strukture terminala, dok je, s druge strane, arhitektonska forma rezultat umjetničke interpretacije pretapanja spomenutih raznolikih konteksta.

Posebnost oblikovanja arhitekture postignuta je kompozicijom ploha hipara blage zakrivljenosti temeljene na dva smjera, sjajno blistavih i čistih površina koje tvore dinamični pokrov zgrade terminala valovitog reljefa čija je glavna značajka da „ledbi“ iznad prostora terminala ostvarujući slobodno preplitanje strukturne mreže. Jednako tako, interijer zrači originalnošću zakrivljenošću svoda i konstrukcije, koja je iskazana množinom štapova i čvorišnih kugli čelične triangularne konstrukcije.

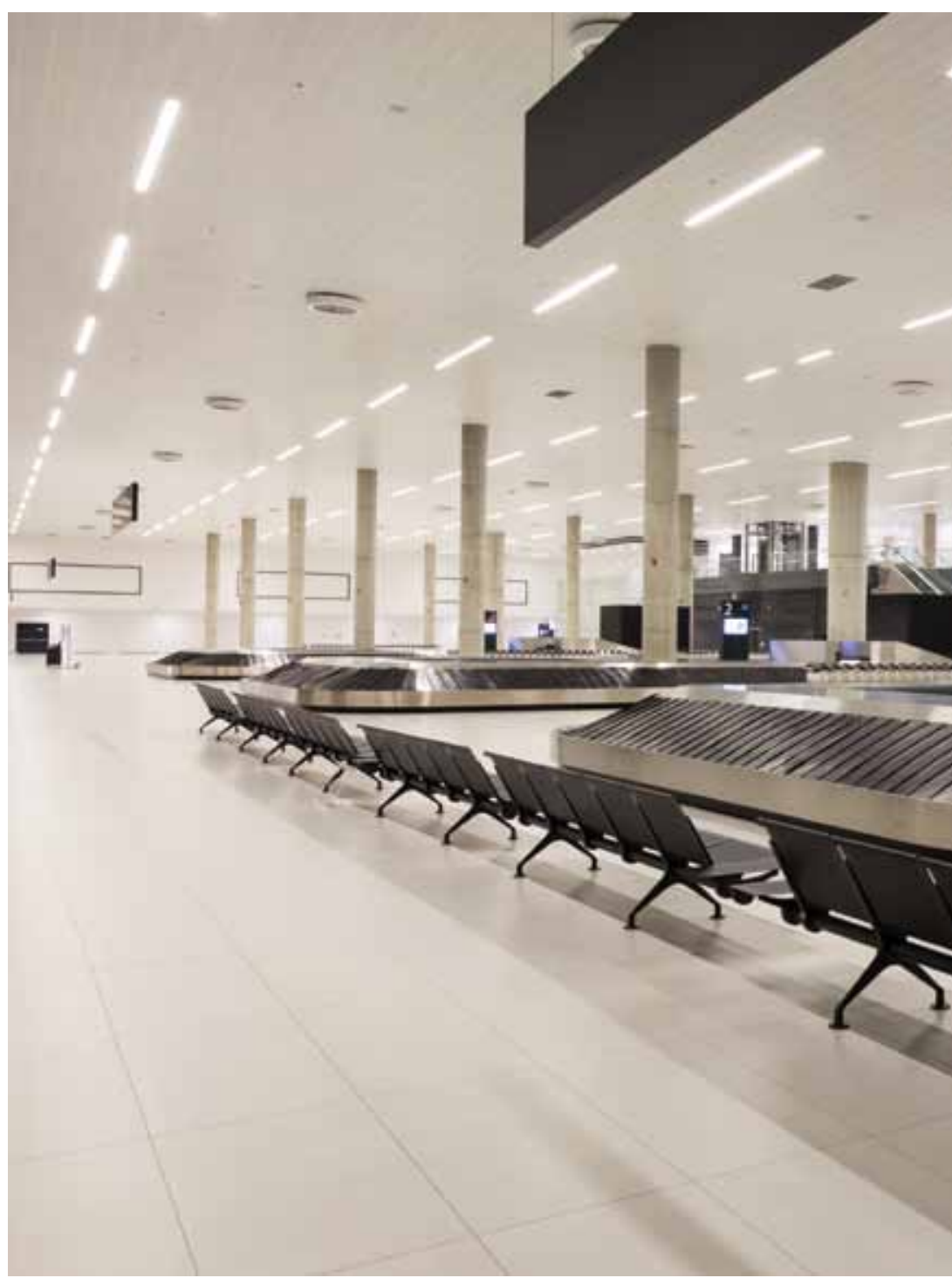




\section{Design}

New Passenger Terminal at Franjo Tudman International Airport Zagreb, interior 18; author: Josip Škof

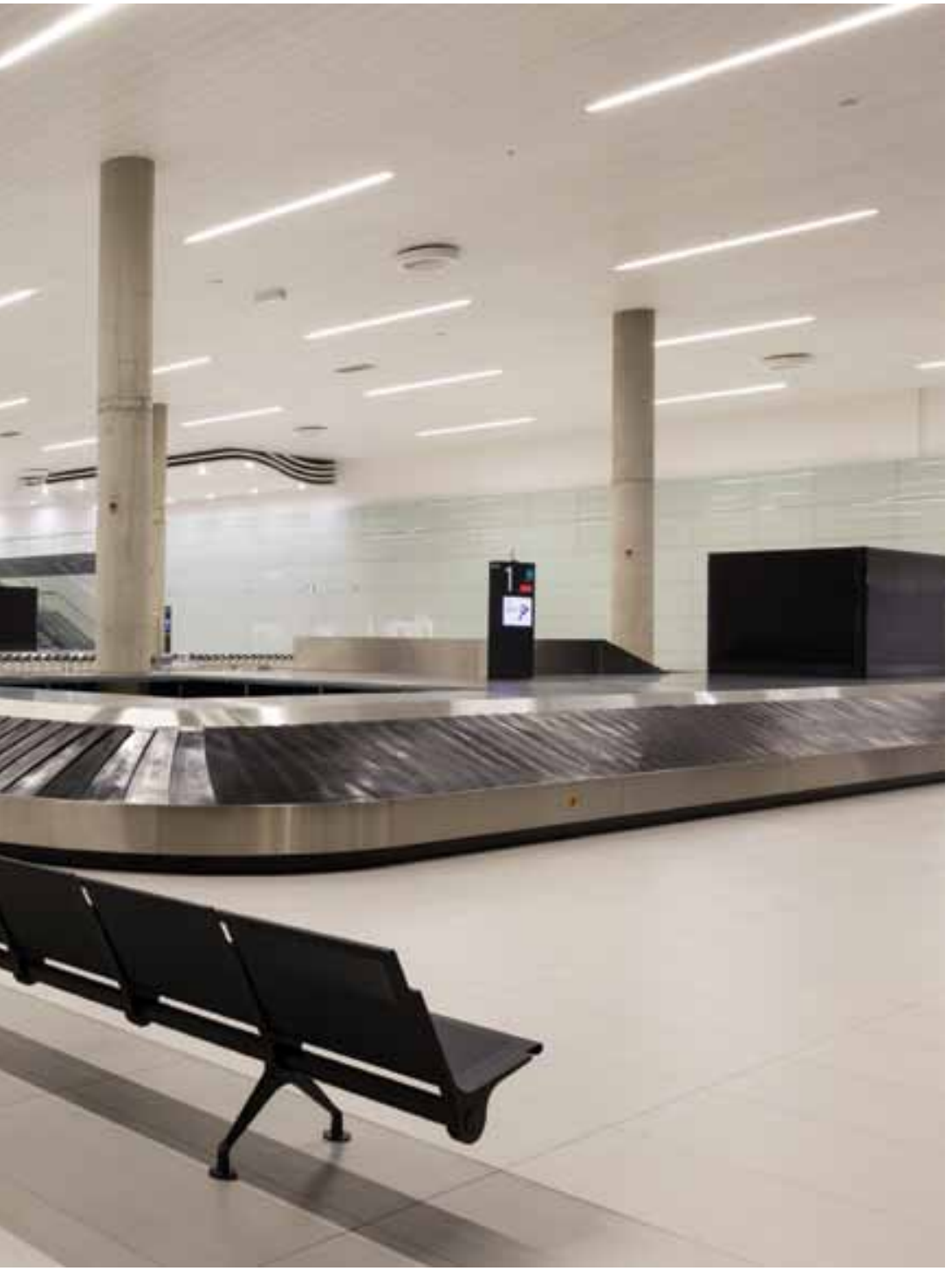

The architectural form of the new passenger terminal of Franjo Tuđman Airport in Zagreb was generated through a unique blend of aesthetic phenomena and functional tasks. It is realised through combinations of analogies of contextual, environmental, symbolic, and historical paradigms of cultural development with a complete openness towards the universality of global cultural forms and the uniqueness of local ones. The manipulation of the attributes of the experience of particular parts of the airport was realised in the design process through an architectural form that bears a clear relationship with context. The architectural form is founded on the strict functional philosophy of the complex structure of the terminal, while simultaneously being the result of an artistic interpretation of the combination of the aforementioned various contexts.

The unique architectural design involves a composition consisting of hyperbolic paraboloid planes with a mild bi-directional curvature, brilliant reflective and clear surfaces that create a dynamic roof to the terminal building with an undulating relief that seems to "float" above the terminal space, creating free interaction of the structural network. Equally so, the interior radiates with the originality of the curvature of the arch and its 


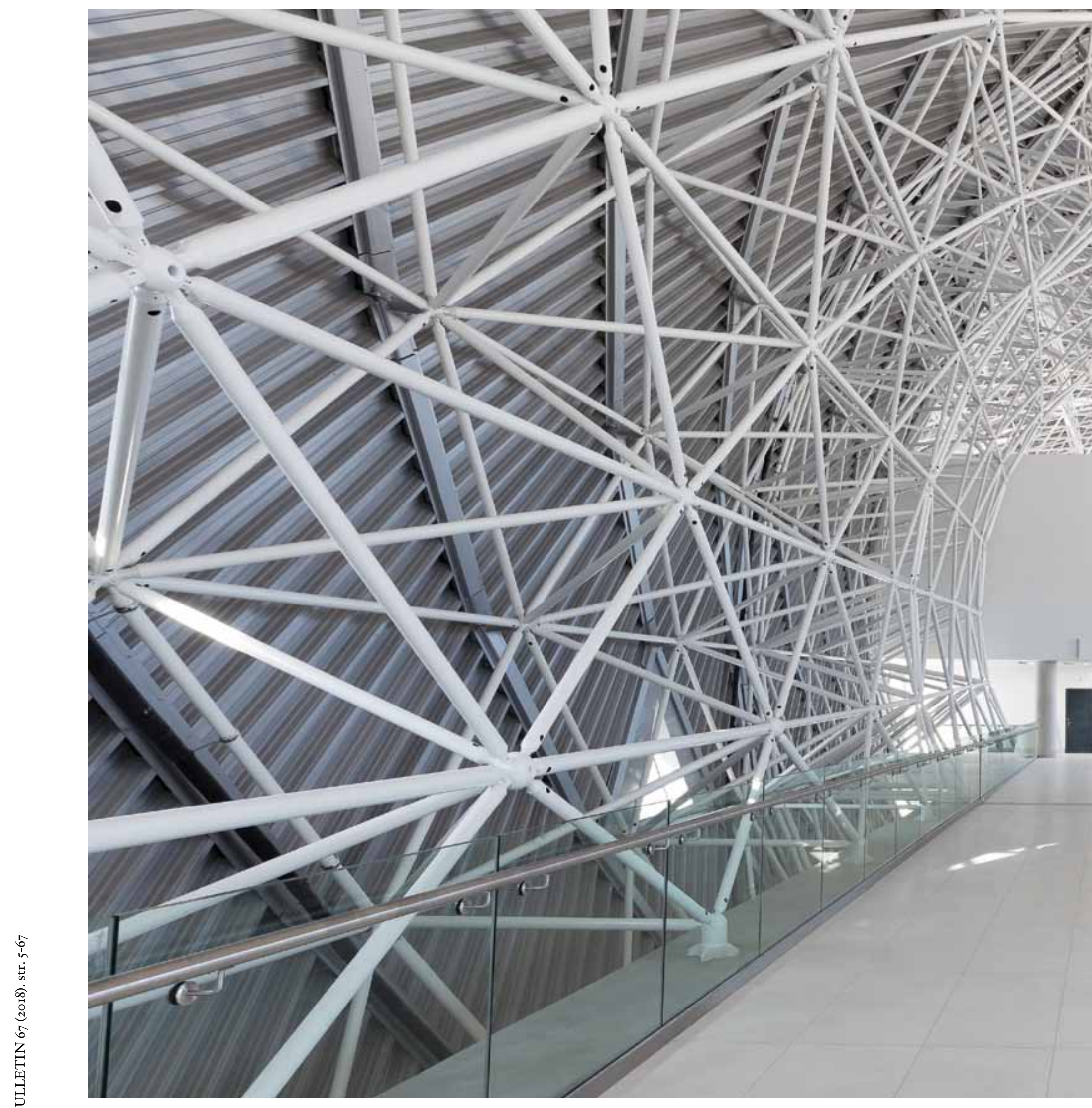

Novi putnički terminal Međunarodne zračne luke

Franjo Tuđman u Zagrebu, interijer 3; autor: Josip Škof 


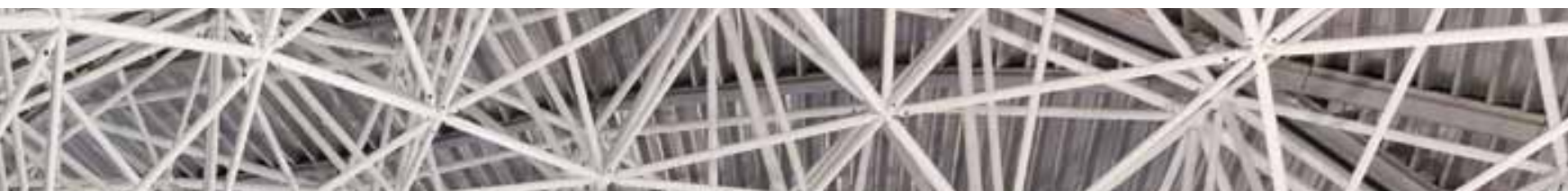

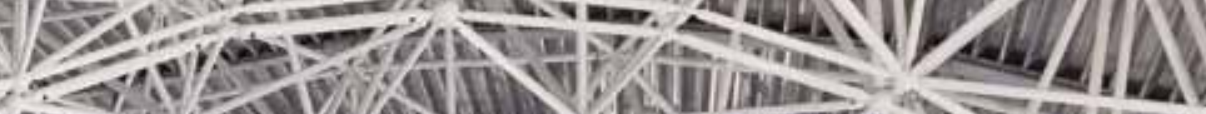

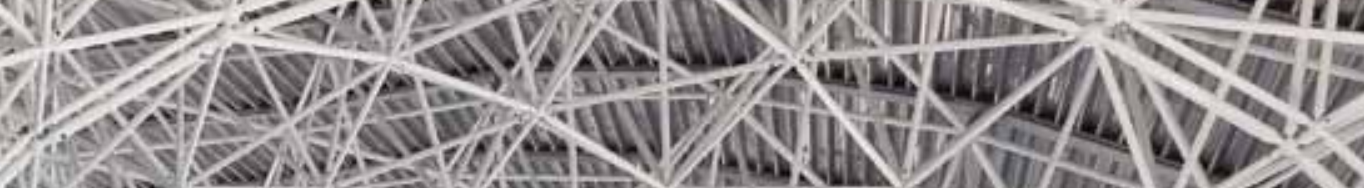

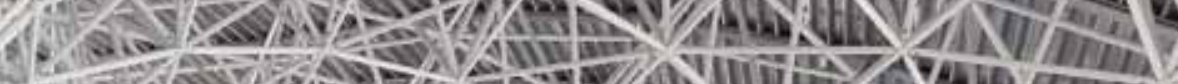

14. 4 .

2. 7 s.

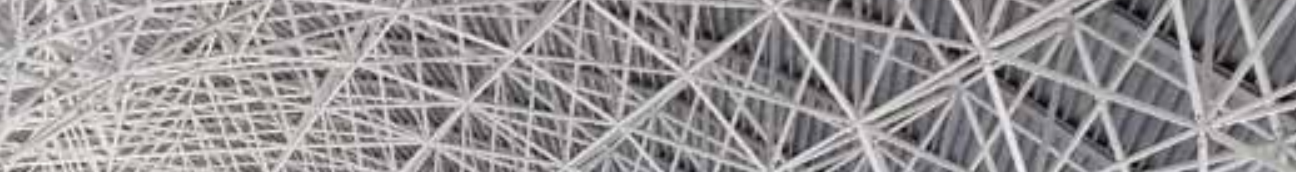

2.1.

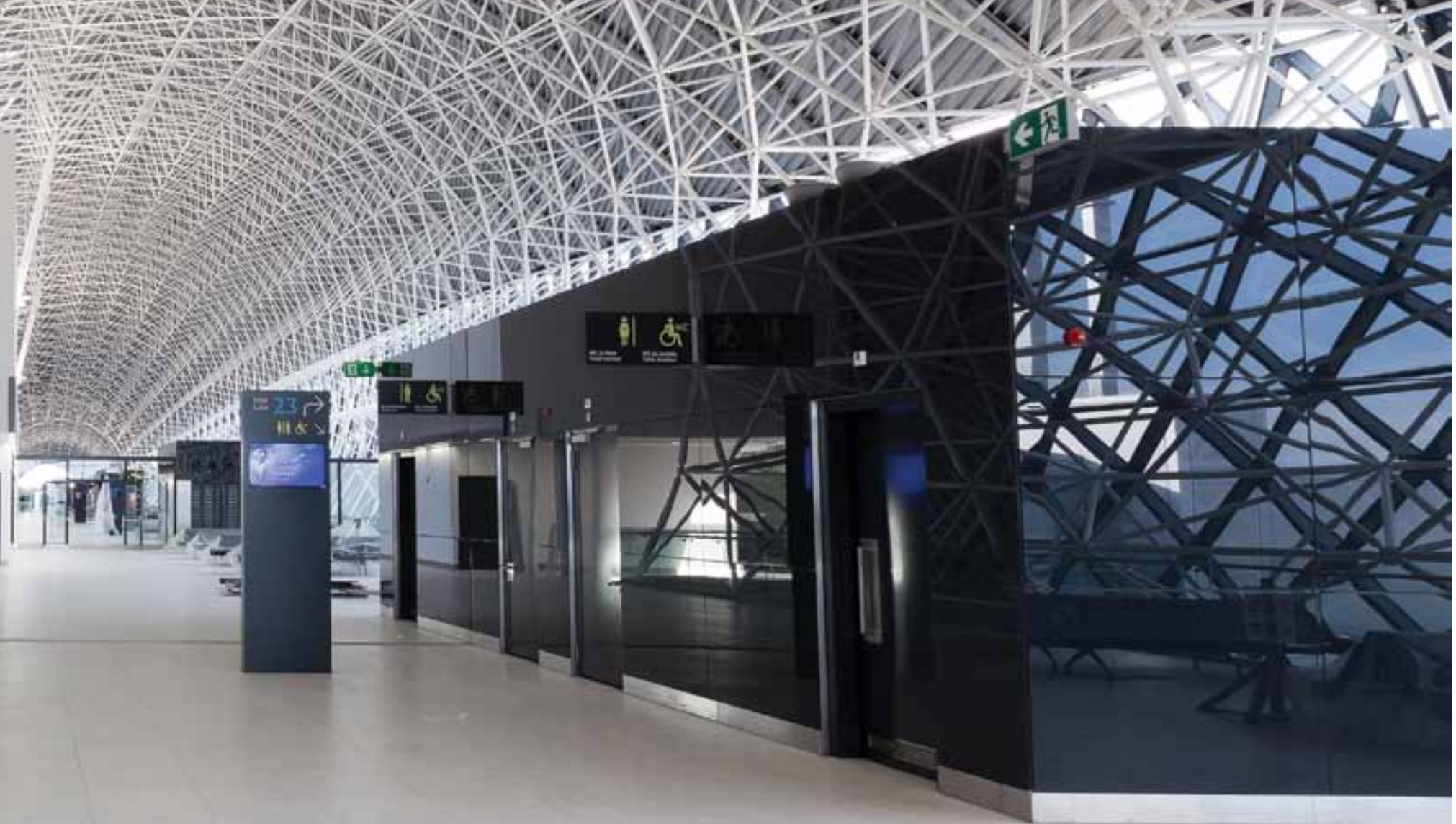
Airport Zagreb, interior 3; author: Josip Škof 
Taj snažni doživljaj svoda u interijeru dopunjen je izvanrednim osvjetljenjem u režimu prirodnog svjetla koje danju dolazi preko staklenih dijelova krova i velikih staklenih ploha pročelja. U večernjim satima prirodno osvjetljenje zamjenjuje se umjetnim, koje je realizirano izborom velikog broja led reflektora usmjerenih u strop, čime se konstrukcija izričito ističe, a prostor je osvijetljen difuzno raspršenim svjetlom koje je najbliže prirodnom osvjetljenju.

Unutrašnjost terminala projektirana je kao sofisticiran, estetski i ekološki ambijent koji nosi obilježja čistih, jasno prostorno organiziranih cjelina koje slijede funkcionalne zahtjeve aerodromskih protokola. Dobro osvijetljeni prostori - prirodnim i umjetnim difuznim svjetlom - odlikuju se funk- construction, expressed in the many bars and central nodes of the triangular steel framework.

This strong experience of the arch in the interior is complemented with exceptional natural lighting, which enters through the glass parts of the roof and the large glass faces of the façade. In the evening hours, natural lighting is replaced with artificial lighting provided through a large selection of LED reflectors pointed at the ceiling; this especially highlights the construction, while lighting the space with diffused light that is as close as possible to natural lighting.

The interior of the terminal has been designed as a sophisticated, aesthetic and ecological ambience that bears the characteristics of a clean, clearly organised whole that follows the func-

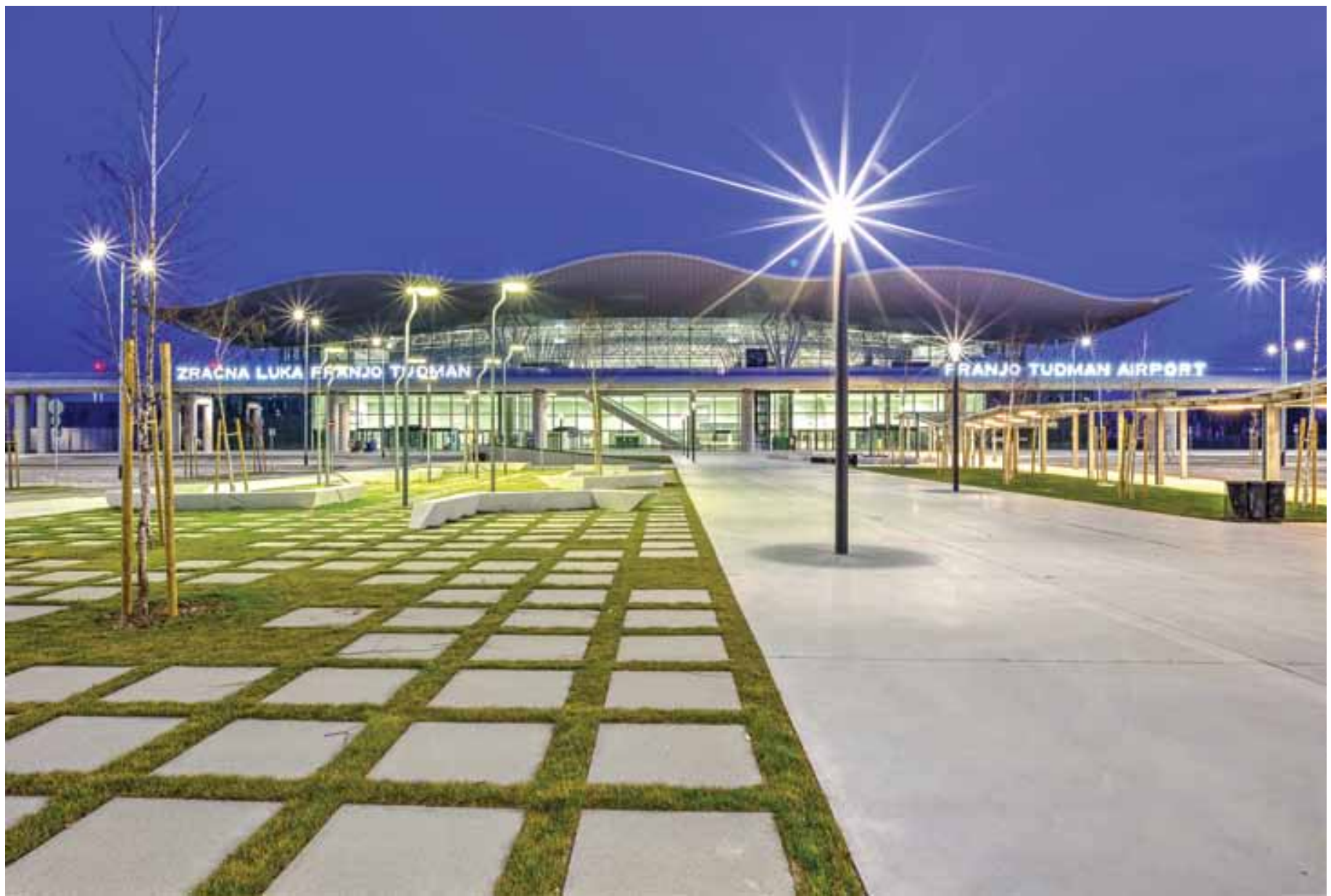

Novi putnički terminal Međunarodne zračne luke Franjo Tuđman u Zagrebu, eksterijer 4; autor: Josip Škof
New Passenger Terminal at Franjo Tudman International Airport Zagreb, exterior 4; author: Josip Škof 
cionalnošću koja se temelji na jasnoj organizaciji kratkih funkcionalnih veza - putova. Prostori jasnih dimenzija i proporcija u bojama svijetlih tonova, $\mathrm{u}$ kontrastu s plohama tamnih boja, sive $\mathrm{i}$ crne, u povezanosti autoriteta smjerova kretanja osiguravaju putnicima logičan tijek ugodnog putovanja.

Na obodnim pročeljima glavne zgrade terminala dominira pravilnost ravnih ostakljenih fasada. Jugozapadna fasada je konačna, dok je sjeveroistočna predložena kao otvorena shema kako bi se u budućnosti mogla izvesti eventualna proširenja. Isti princip primijenjen je na bočnim fasadama oba izdanka, koji će u budućnosti biti također produžavani kako bi u perspektivi prihvatili potreban veći broj aviomostova. Jednostavnosti i tional demands of airport protocols. The spaces, well-lit with both natural and diffused artificial lighting, bear a functionality based on the clear organisation of short functional connections and paths. The clear dimensions and proportions of the spaces in light colours, contrasted with dark grey and black planes indicating the priority of directions of movement, ensure passengers a logical, comfortable flow on their travels.

The peripheral façades of the main terminal building are dominated by the regularity of straight glass surfaces. The southwestern façade is final, while the northeastern is provided as an open-ended schema so that potential expansions might be carried out in the future. The same principle has been applied to the side façades of both

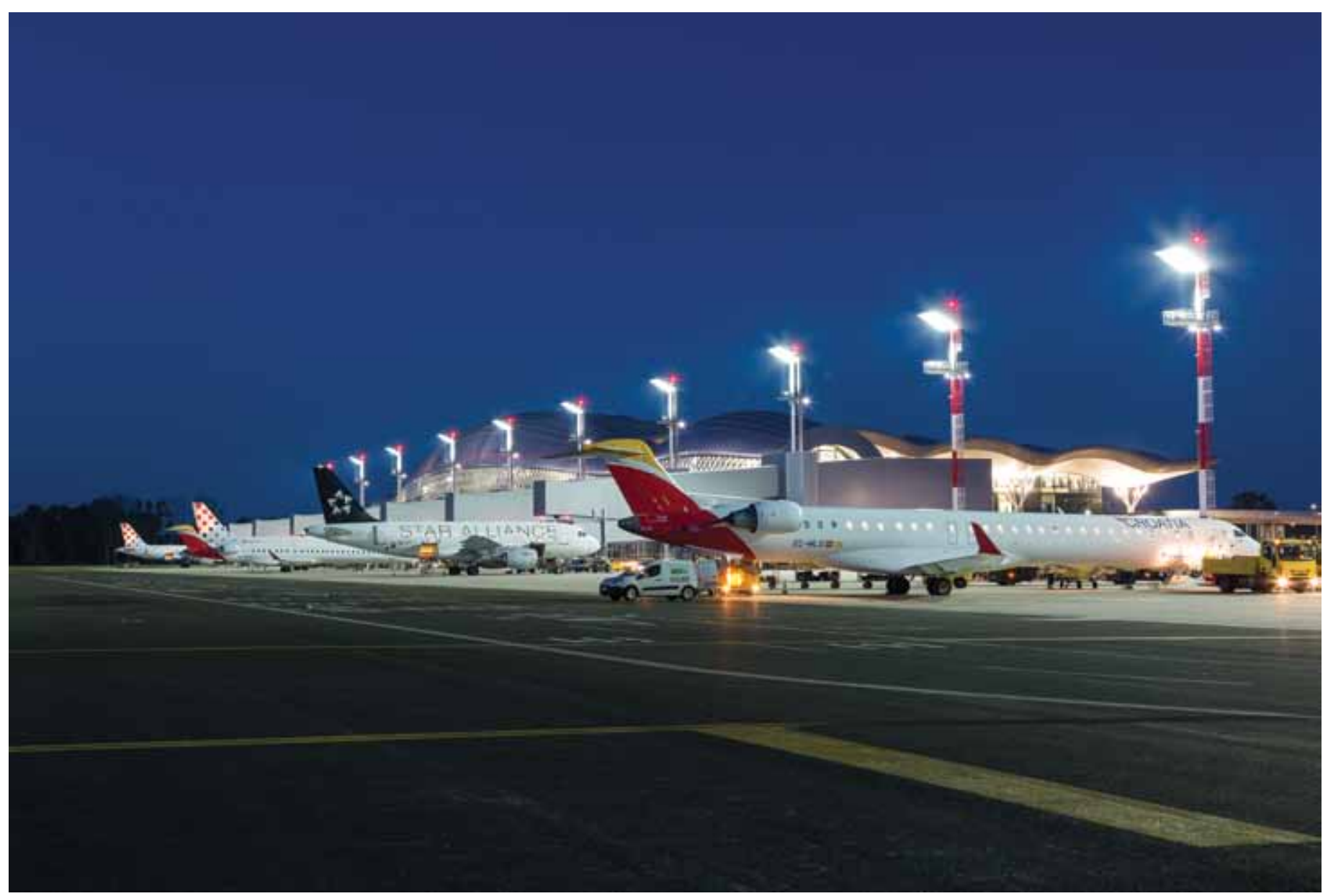

Novi putnički terminal Međunarodne zračne luke Franjo Tuđman u Zagrebu, eksterijer 17; autor: Josip Škof
New Passenger Terminal at Franjo Tudman International Airport Zagreb, exterior 17; author: Josip Škof 
proširivosti rješenja pogoduje jasnoća i racionalnost modularnog tlocrta.

Velike staklene plohe pročelja pružaju mogućnost da slike okoliša prate putnika u kretanju prostorima terminala - s južne strane panorama šume Turopolja, sa sjeverne strane neposredna vizualna iskustva dinamične estetike urbanih veduta grada Zagreba i Medvednice te zelene parkovne površine s istočne strane. Doživljaj vanjske i unutrašnje prostornosti pridonosi osjećaju ugode boravljenja u terminalu i putovanje čini privlačnim. Uz zadovoljstvo putnika, tu arhitekturu odlikuje visoka doza ljudskosti, humanosti, uz zadovoljavanje najviših funkcionalnih, ergonomskih i sigurnosnih standarda. Osmišljen je ugodan i nezaboravan ambijentalni doživljaj suvremene arhitekture piers, which will also be lengthened in order to handle a larger number of jetways. The clarity and rationality of the modular floor-plan contributes to the simplicity and scalability of the design.

The large glass façades allow images of the surrounding area to follow passengers as they move through the terminal - the forests of Turopolje to the south, the direct visual experience of the dynamic aesthetics of Zagreb's urban panoramas and Medvednica mountain to the north, and green park areas to the east. The experience of exterior and interior space contributes to a feeling of comfort while in the terminal and makes travelling appealing. In addition to passenger satisfaction, the architecture displays a high dose of humanity while satisfying the highest functional, ergo-

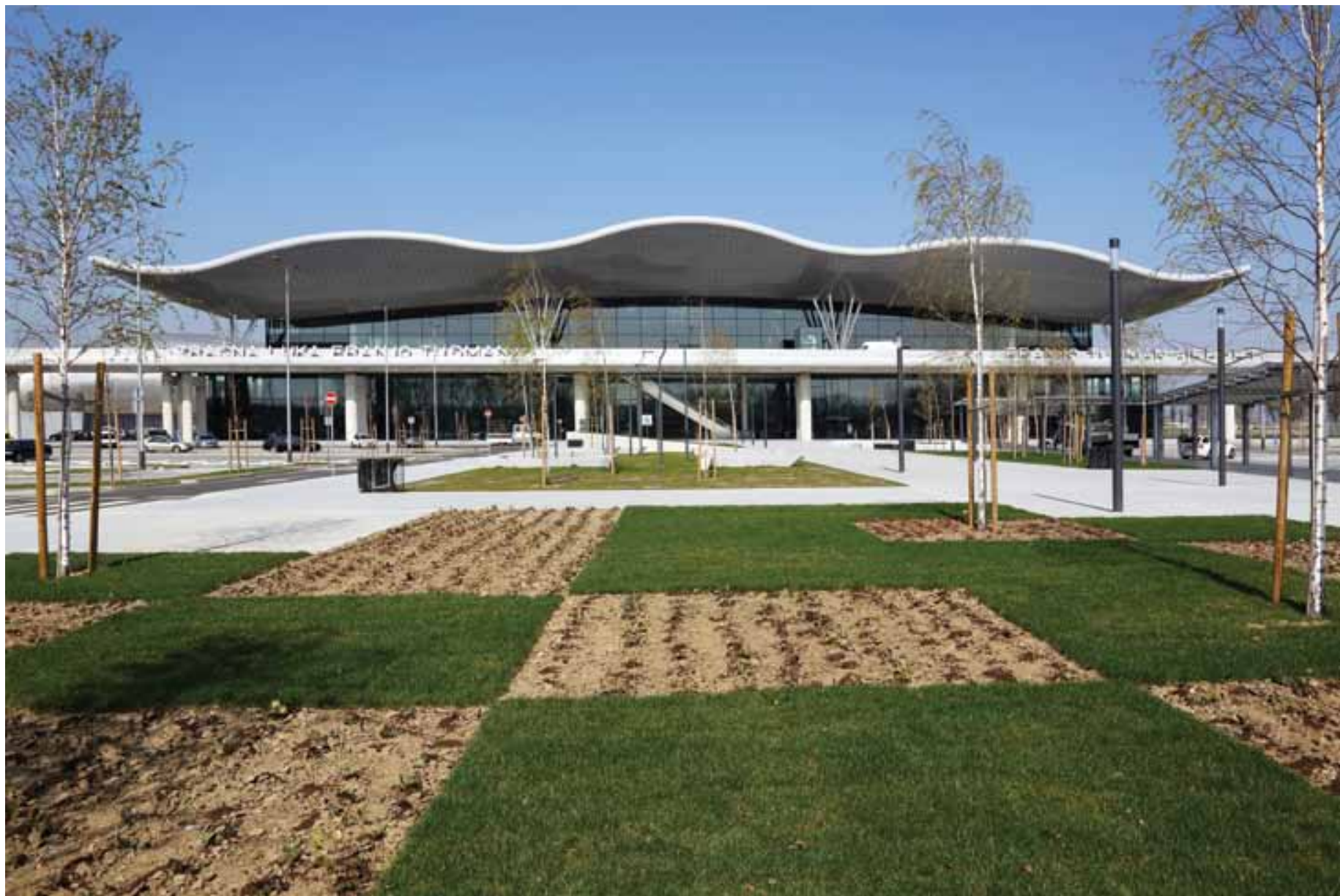

Novi putnički terminal Međunarodne zračne luke Franjo Tuđman u Zagrebu, eksterijer 1; autor: Damir Fabijanić
New Passenger Terminal at Franjo Tudman International Airport Zagreb, exterior 1; author: Damir Fabijanić 
s originalnim prirodnim oblicima arhitektonske krovne ovojnice koja otkriva posebnost prostorne dinamike unutrašnjosti javnih prostora novog putničkog terminala.

Osebujne estetske atribucije otkrivaju arhitekturu kao semiotički emitivni faktor raznolikih značenja, od jednostavnih prikaza preko znakovnih analogija do najviših simboličkih razina. $\mathrm{Na}$ ovome mjestu treba istaknuti značajke umjetničke interpretacije arhitektonskog oblika, posebno ovojnice, u povezanosti sa zahtjevnosti inženjerske interpretacije materijalizacije arhitektonske ideje koja je rezultat niza postupaka provedenih kompjutorskim modeliranjem. nomic, and security standards. It creates a comfortable, unforgettable atmospheric experience of modern architecture with the original, natural forms of its architectural roof covering, which reveals the unique spatial dynamics of the interiors of the new passenger terminal's public areas.

The distinctive aesthetic attributes of the complex reveal architecture as a semiotic emissive factor with various meanings, from simple portrayals and semiotic analogies to the highest level of symbolism. The characteristics of the artistic interpretation of the architectural form must be noted here, especially of the mantle, as related to the demanding engineering interpretation of the materialisation of an architectural idea resulting from a series of processes derived through computer modelling.

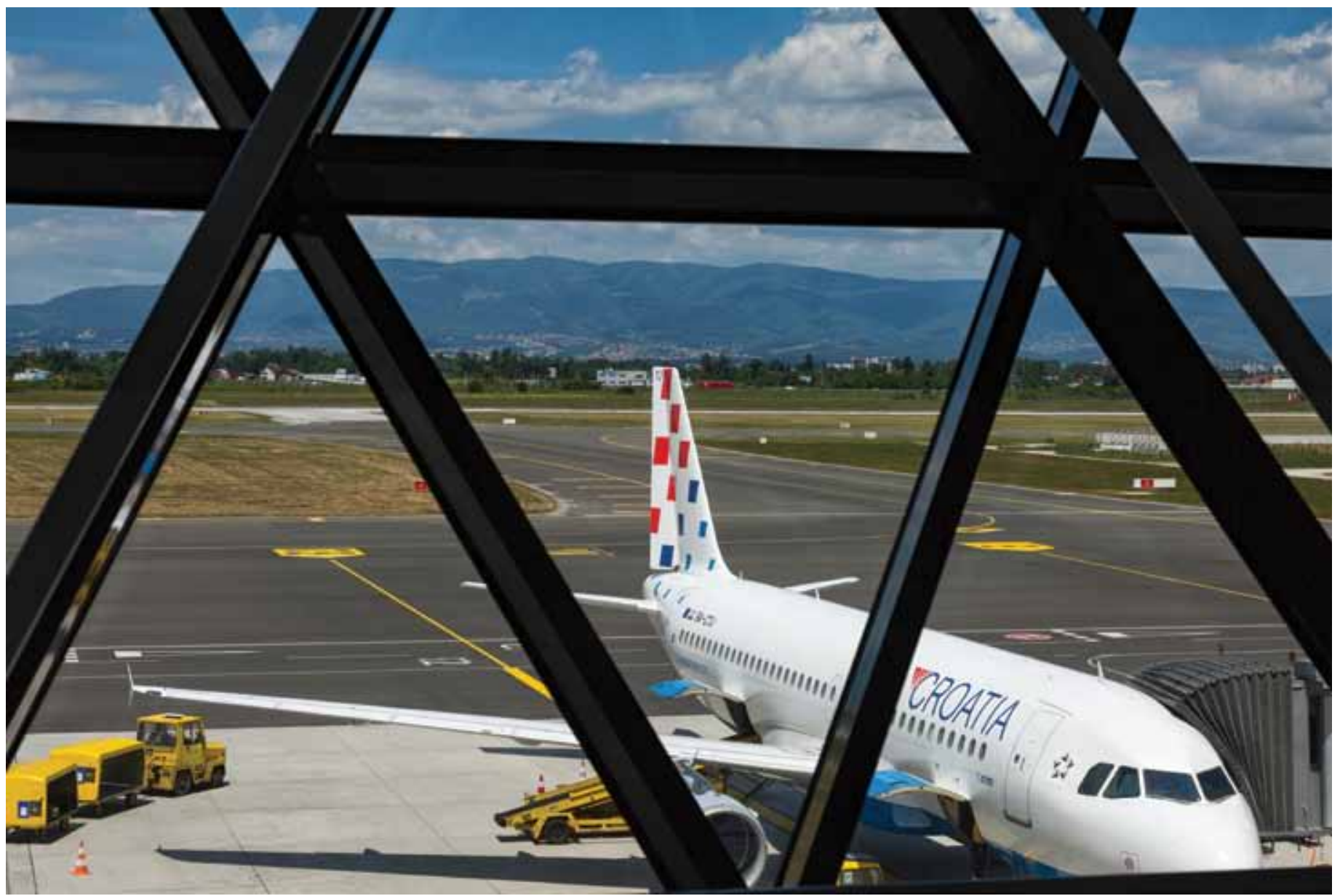

Novi putnički terminal Međunarodne zračne luke Franjo Tuđman u Zagrebu, interijer 21; autor: Josip Škof
New Passenger Terminal at Franjo Tudman International Airport Zagreb, interior 21; author: Josip Škof 


\section{Fleksibilnost}

Fleksibilnost konceptualne sheme koja osigurava adaptabilnost, odnosno prilagodljivost rastućim ili mijenjajućim se potrebama za optimalno funkcioniranje terminala osnova je pristupa projektiranju te, uz to, omogućuje racionalno korištenje prostora u svakoj novozadanoj situaciji razvoja prometa. Ona počiva na dva geometrijska sustava: dinamičnoj linearnoj strukturi izdanaka i na kompaktnom tlocrtnom planu glavnoga hala $\mathrm{u}$ središtu terminala temeljenom na prevladavajućoj modularnoj mreži rastera 7,20 x 7,20 m, 7,20 x $14,40 \mathrm{~m}, 14,40 \times 14,40 \mathrm{~m}$.

Glavni središnji hal slobodnim tlocrtnim planom omogućuje fleksibilnost osnovnih funkcionalnih cjelina prijave putnika, na galeriji sigurnosne provjere i provjere putovnica vezanih za promjene putničkih tokova i njihove kapacitete (domaći - internacionalni, Schengen/non-Schengen). Prostor glavnoga hala moguće je također, zbog povećanja prometa, proširiti prema sjeveroistoku, ovisno o potrebnim kapacitetima u budućnosti.

Na izdancima je fleksibilnost postignuta veli-
Novi putnički terminal Međunarodne zračne luke Franjo Tuđman u Zagrebu, eksterijer 11; autor: Josip Škof

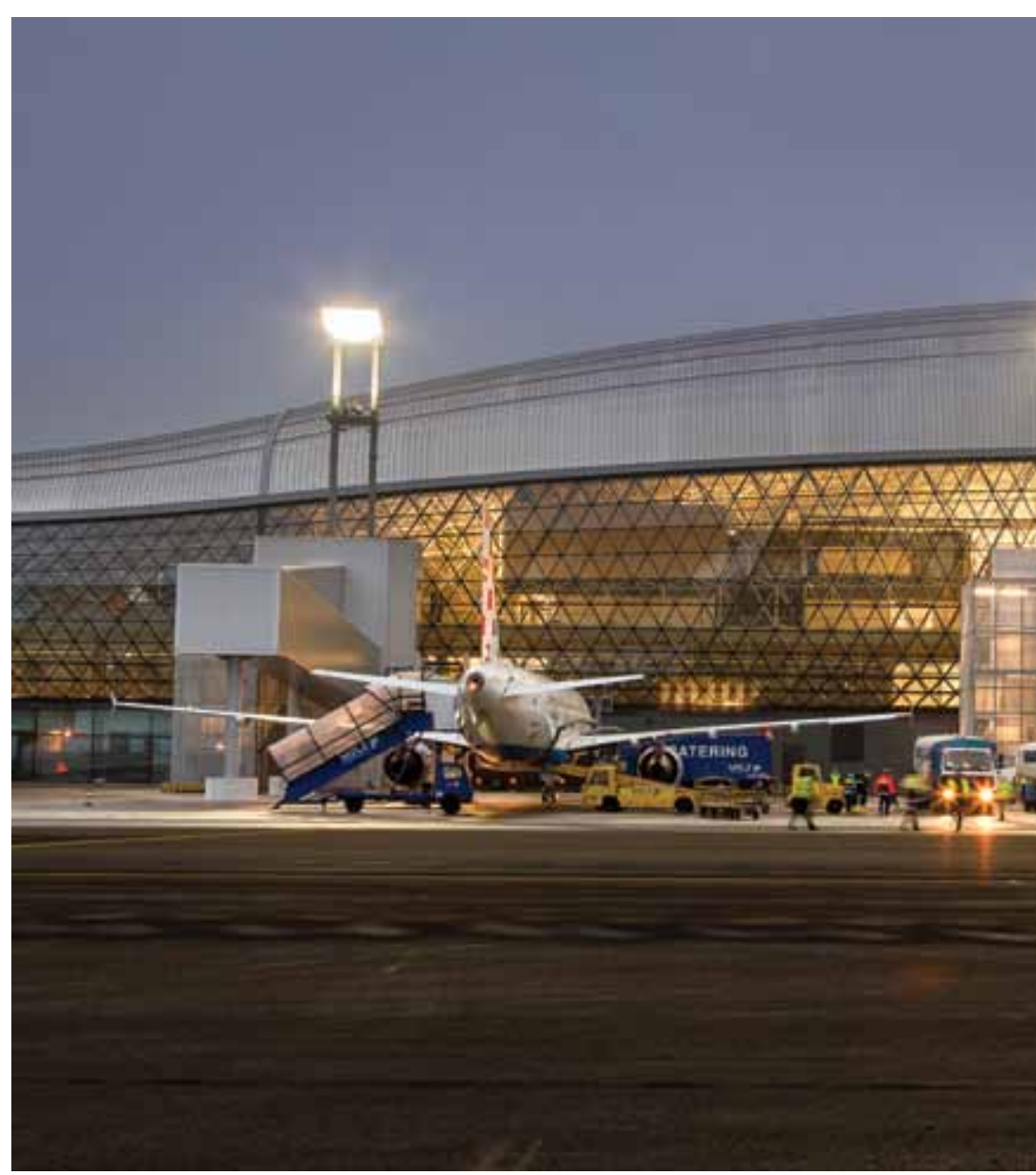




\section{Flexibility}

New Passenger Terminal at Franjo Tudman International Airport Zagreb, exterior 11; author: Josip Škof

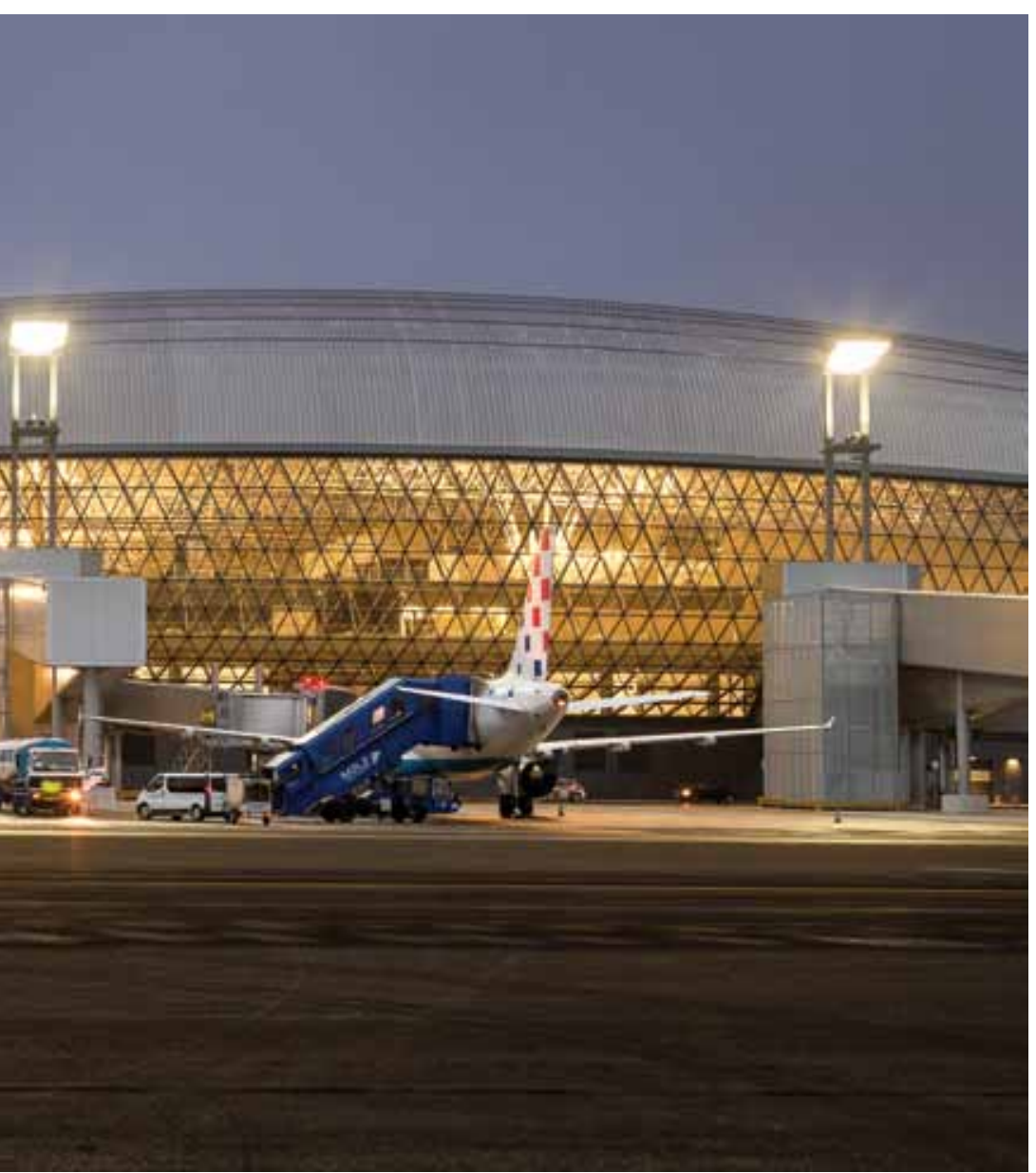

The flexibility of the conceptual schema, which ensures adaptability to growing or changing needs that must be satisfied for the terminal to function optimally, is the basis of the approach to design. Additionally, it enables the rational use of space in each new situation in the development of traffic. It is founded on two geometric systems: the dynamic linear structure of the piers and the compact floor-plan of the main hall in the centre of the terminal, based on an overarching modular network measuring $7.20 \times 7.20 \mathrm{~m}, 7.20 \times 14.40 \mathrm{~m}$, $14.40 \times 14.40 \mathrm{~m}$.

The open floor-plan of the central hall enables flexibility for changes in passenger flows and their capacities in the basic functional units for passenger check-in, in the security gallery, and in the passport check area (international, Schengen/ non-Schengen). The main hall can also be expanded to the northeast depending on required capacities in the future.

Flexibility is achieved in the piers through the large areas located beneath the roof envelope. The flexibility of the piers allows them to expand linearly both eastward and westward in accordance with growing air traffic and the need for a larger number of jetways. Outside the building itself, the size of the ramps can be increased in accordance with an increase in the number of piers, as well as with an increased number of external aprons without access to jetways. 


\section{Arhitektonska forma i konstrukcija}

\section{Architectural form and construction}

Arhitektonska forma predstavljena je svojim volumenima i plohama, dok je konstruktivni model prikazan prostornom matricom nosivih elemenata, s dvije osnovne strukture, armiranobetonskom i čeličnom.

Armiranobetonska konstrukcija s naknadnim prednaprezanjem izvedena je u modularnoj mreži s različitim rasponima koji su multiplikanti osnovnog modula: 7,20 m, 14,40 m itd. Ona je prostorni okvir unutar kojeg se odvijaju procesi organizacije i obrade tokova putnika i prtljage, sastavljen od tri dilatirana dijela: glavne zgrade te zapadnog i istočnog izdanka. Stropne konstrukcije kombinacija su dijelova od naknadno napregnutih AB stropnih elemenata greda i ploča, stabilizacija $A B$ konstrukcije predviđena je $s 4$ vertikalne jezgre i $A B$ seizmičkim zidovima, dok je temeljenje $\mathrm{AB}$ konstrukcije pretežno na temeljnim stopama, temeljnim trakama ispod $\mathrm{AB}$ zidova i temeljnim pločama ispod vertikalnih jezgri.

Unutar te strukture horizontalno i vertikalno povezanih prostora smješteno je 18 armiranobetonskih stupova - pilona promjera $150 \mathrm{~cm}(170 \mathrm{~cm}$ na 2. katu) koji preko stožastih snopova od po 6 čeličnih stupova na vrhu nose čeličnu kostrukciju krovne envelope.
The architectural form is represented through the building's volumes and planes, while the structural model is portrayed through the spatial matrix of load-bearing elements with two basic structures - one made of reinforced concrete and one made of steel.

The post-tensioned reinforced concrete structure consists of a modular network with various lengths that are multiples of the basic module: $7.20 \mathrm{~m}, 14.40 \mathrm{~m}$. It is the spatial framework within which passenger and luggage flow organisation and processing unfold, composed of three dilated parts: the main building and the western and eastern piers. The roof construction is a combination of parts made from post-tensioned $A B$ roof beams and panels; $A B$ structure stabilisation is foreseen with four vertical cores and $A B$ seismic walls, while the foundation of the $A B$ structure rests mainly on footing, on strip foundations under the $A B$ walls, and on ground slabs under the vertical cores.

This structure of horizontally and vertically connected spaces includes 18 reinforced concrete columns - pylons $150 \mathrm{~cm}$ in diameter $(170 \mathrm{~cm}$ on the 2nd floor), which bear the steel structure of the roof envelope on conical bundles of six steel columns. 
Sama krovna konstrukcija čelična je prostorna rešetkasta „mero“ konstrukcija sastavljena od cijevnih elemenata koji se na gradilištu montažno spajaju. Geometrija prostorne rešetke izvedena je $\mathrm{u}$ modularnom rasteru od 360 x $360 \mathrm{~cm}$ s visinom konstrukcije od 3,0o m, s tim da su osi gornjeg pojasa izmaknute u odnosu na osi donjeg pojasa za $180 \mathrm{~cm}, \mathrm{u}$ tzv. offset izvedbi. Takav način izvedbe uz zakrivljenost plohe envelope $u$ interijeru pridonosi bogatstvu elemenata čelične konstrukcije stvarajući igrom svjetla i sjene bezbroj originalnosti i atraktivnosti. Oblikovanje konstrukcijom s dva lica krovne envelope te s vanjskom plohom krova blage zakrivljenosti u kontrastu s bogatstvom strukture konstrukcije unutrašnjosti još je jedna od posebnosti ovoga projekta.

Vanjski plašt zgrade uz ovojnicu zakrivljene geometrije kojom su pokriveni krov i izdanci sastavljen je i od strukturalne aluminijske izolirajuće ostakljene konstrukcije pročelja glavne zgrade s modulom 360 x $240 \mathrm{~cm}$. U transparentnom dijelu to je aluminijska strukturalna fasada s izolirajućim staklima, a u neprovidnom dijelu također strukturalna - na vanjskoj plohi alufasada s emajliranim staklom ili s aluminijskim griljama na potezima instalacijskih prodora. Alufasada počiva na fasad-
The steel structure of the roof itself is a spatial latticework composed of pre-fabricated pipe elements assembled at the building site. The geometry of the spatial latticework is executed in a modular network measuring $360 \times 360 \mathrm{~cm}$ with a height of 3.0om; the axis of the upper belt is offset from the axis of the lower belt by $180 \mathrm{~cm}$. This method, alongside the curving of the plane of the envelope into the interior, contributes to the richness of elements in the steel construction, creating an endlessly original and appealing play of light and shadow. The design of the structure with two roof envelope faces and with a mildly curved external roof plane, contrasted with the rich structure of the interior, is yet another special feature of this project.

The exterior mantle of the building alongside the curved envelope covering the roof and piers is also composed of the main building's insulating structural aluminium and glass façade, with a module of $360 \times 240 \mathrm{~cm}$. The transparent part consists of an aluminium structural façade with insulated glass. The opaque part is also structural - the exterior plane of the aluminium façade is covered with enamelled glass or aluminium grating covering access ducts. The aluminium façade rests on a 
noj čeličnoj konstrukciji s vertikalnim stupovima na razmaku $360 \mathrm{~cm}$. Modul strukturalnog ostakljenja zakrivljenih dijelova ovojnice jest trokutasti s bazom jedinice trokuta od $180 \mathrm{~cm}$.

Kompjutorsko modeliranje te rad organiziran metodom integralnog projektiranja koji su realizirali timovi projektanata pratio je stručni tim koncesionara. Isto tako proces projektiranja pratio je neovisni nadzorni inženjer. steel structure with vertical columns $360 \mathrm{~cm}$ apart. The module of the structural glazing of the curved parts of the envelope is triangular, with individual triangular bases measuring $180 \mathrm{~cm}$.

A professional team employed by the concessionaire supervised computer modelling and integral design work undertaken by teams of designers. The design process was also monitored by an independent supervising engineer.

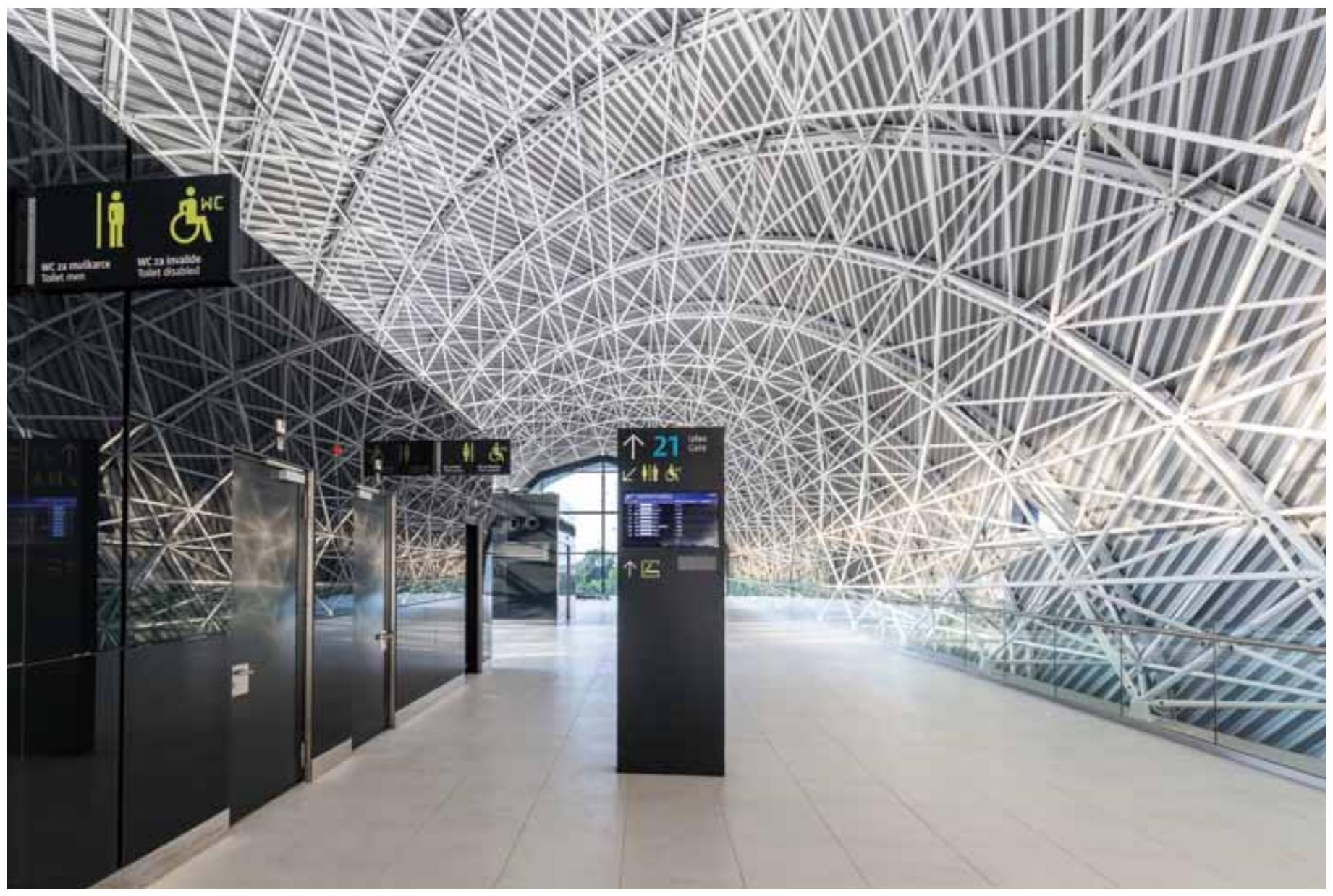

Novi putnički terminal Međunarodne zračne luke Franjo Tuđman u Zagrebu, interijer 4; autor: Josip Škof
New Passenger Terminal at Franjo Tudman International Airport Zagreb, interior 4; author: Josip Škof 


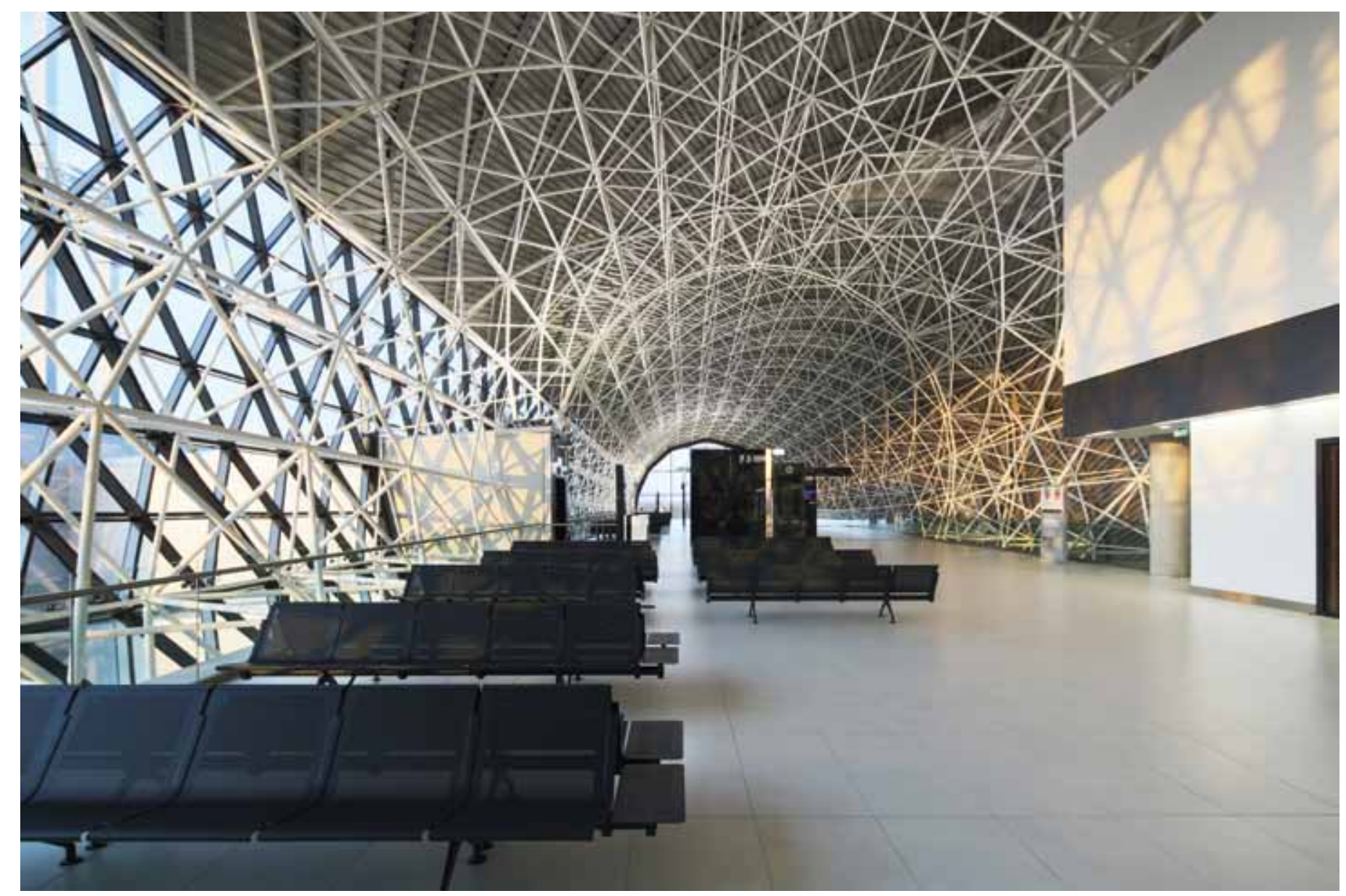

Novi putnički terminal Međunarodne zračne luke Franjo Tuđman u Zagrebu, interijer 5; autor: Damir Fabijanić
New Passenger Terminal at Franjo Tudman International Airport Zagreb, interior 5; author: Damir Fabijanić 


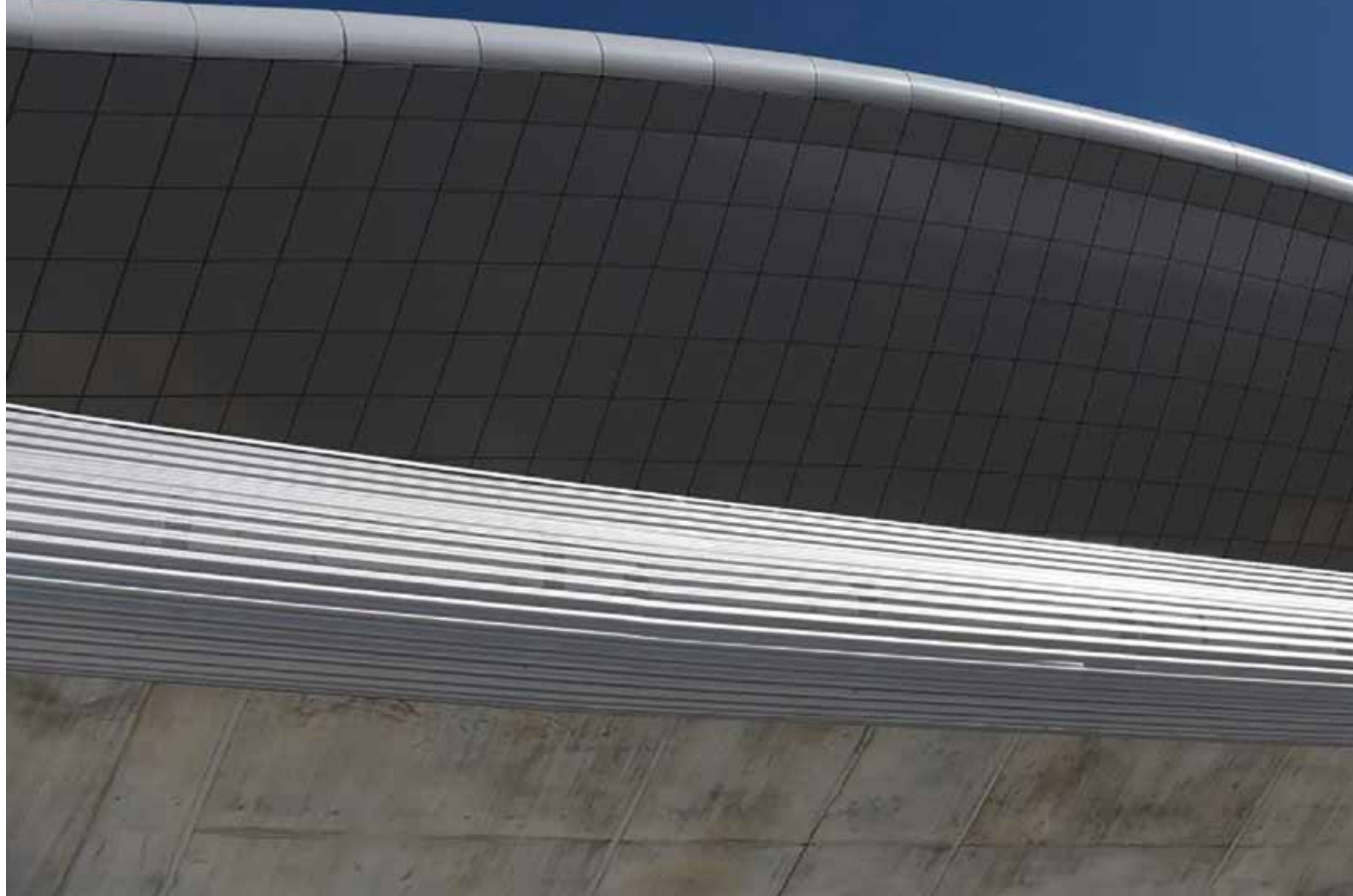

Novi putnički terminal Međunarodne zračne luke Franjo Tuđman u Zagrebu, eksterijer 13, detalj nadstrešnice krova; autor: Damir Fabijanić 


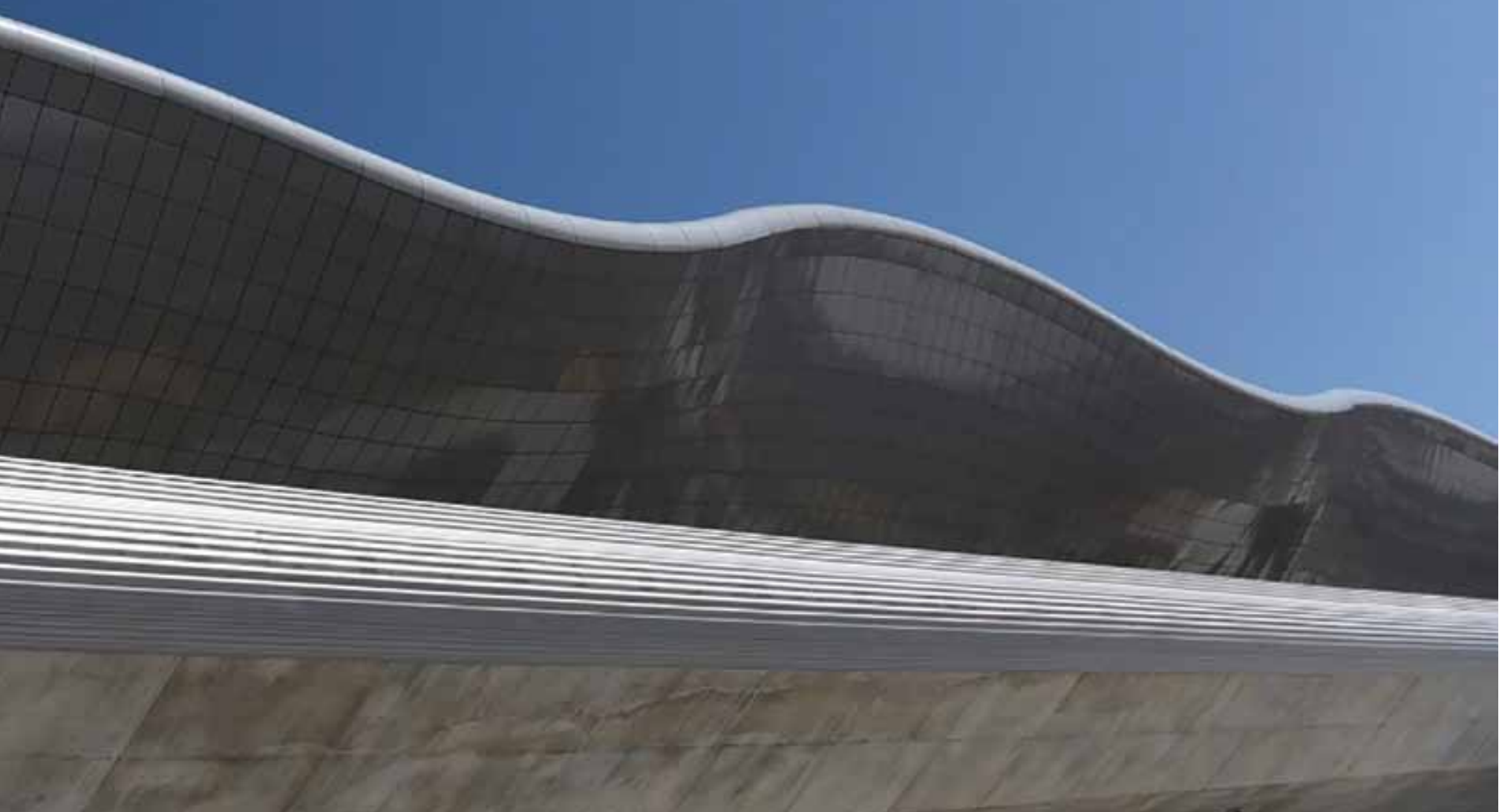

New Passenger Terminal at Franjo Tudman International Airport Zagreb, exterior 13, roof canopy detail; author: Damir Fabijanić 


\section{Ekološka održivost}

Zeleni koncept prožima cjelinu projekta te je zgrada novog putničkog terminala projektirana da nadvlada snažne energetske krizne momente prouzročene prekidom svih standardnih dotoka energije. Ekološkoodrživi koncept projektiranja temelji se na sljedećim postavkama:

- prikupljanje oborinskih voda s površina kompleksa, s procesuiranjem i distribucijom (odvodnja oborinskih voda s krova terminala predviđena je spajanjem na sabirni spremnik kišnice iz kojeg se voda koristi za ispiranje WC uređaja i pisoara; preljev iz spremnika kišnice priključuje se na interni oborinski kolektor (obrađen posebnim projektom), kojim se višak oborinske vode odvodi u retenciju čiste vode;

- sveobuhvatna kontrola i upravljanje svim energetskim i instalacijskim sustavima i priključcima s odgovarajućim upravljačkim sustavima;

- upotreba velikih ostakljenih površina i na 30\% ploha arhitektonske ovojnice koja obuhvaća krovne površine, kako nad zgradom tako i na izdancima, što omogućuje penetraciju značajnih količina prirodnog svjetla u dubinu zgrade, čime se ostvaruju energetske uštede na osvjetljenju umjetnom rasvjetom.

Uz navedeno, zgradi je dodijeljen međunarodno priznati certifikat zelene gradnje LEED $^{\circledR}$
Environmental sustainability

Environmental sustainability is interwoven into the entire project; the new passenger terminal building has been designed to overcome severe energy crisis caused by a break in all standard inflows of electrical energy. The ecologically sustainable design concept is founded on the following principles:

- collecting rainwater from the surfaces of the complex with processing and distribution (rainwater is drained from the roof of the terminal to a central collector for use in toilets and urinals; overflow from the rainwater collector is attached to an internal rainwater collector [designed in a separate project] which draws the overflow into clean water retention;

- comprehensive control and management of all electrical systems, installations, and connections through appropriate control systems;

- use of large glass surfaces across $30 \%$ of the surface of the architectural envelope including roof surfaces, both above the building and the piers, which enables significant quantities of natural light to penetrate deep into the building, resulting in energy savings on artificial lighting.

In addition to this, the building has been awarded an internationally recognised Leadership in Energy and Environmental Design sustainable 
(Leadership in Energy and Environmental Design) razine Leed Silver, kreiran u U.S. Green Building Councilu.

Novi putnički terminal Zračne luke Franjo Tuđman u Zagrebu autora Branka Kincla, Velimira Neidhardta i Jure Radića, uz sudjelovanje na nekoliko internacionalnih izložbi i natječaja, dobitnik je međunarodne nagrade American Architecture Prize u kategoriji Architectural Design/ Transport za 2017. godinu te je prezentiran kao jedan od finalista World Architecture Festivala 2017. u Berlinu. building certificate at the Leed Silver level, created by the U.S. Green Building Council.

In addition to participation at a few international exhibitions and competitions, the new passenger terminal of Franjo Tuđman Airport in Zagreb, designed by Branko Kincl, Velimir Neidhardt, and Jure Radić has won the American Architecture Prize in the Architectural Design/ Transport category for 2017. It has also been presented as a finalist at the 2017 World Architecture Festival in Berlin. 
